\title{
Removal of uranium from aqueous wastes using electrically charged carbon nanofibers
}

\author{
Shannon Lee Stover \\ West Virginia University
}

Follow this and additional works at: https://researchrepository.wvu.edu/etd

\section{Recommended Citation}

Stover, Shannon Lee, "Removal of uranium from aqueous wastes using electrically charged carbon nanofibers" (2000). Graduate Theses, Dissertations, and Problem Reports. 1142.

https://researchrepository.wvu.edu/etd/1142

This Thesis is protected by copyright and/or related rights. It has been brought to you by the The Research Repository @ WVU with permission from the rights-holder(s). You are free to use this Thesis in any way that is permitted by the copyright and related rights legislation that applies to your use. For other uses you must obtain permission from the rights-holder(s) directly, unless additional rights are indicated by a Creative Commons license in the record and/ or on the work itself. This Thesis has been accepted for inclusion in WVU Graduate Theses, Dissertations, and Problem Reports collection by an authorized administrator of The Research Repository @ WVU. For more information, please contact researchrepository@mail.wvu.edu. 


\title{
REMOVAL OF URANIUM FROM AQUEOUS WASTES USING ELECTRICALLY CHARGED CARBON NANOFIBERS
}

\author{
Shannon L. Stover
}

\author{
Thesis submitted to the \\ College of Engineering and Mineral Resources \\ at West Virginia University \\ in partial fulfillment of the requirements \\ for the degree of
}

\section{Master of Science \\ In \\ Chemical Engineering}

\author{
John Zondlo, Ph.D., Chair \\ Elliot Kennel \\ Peter Stansberry, Ph.D. \\ Charter Stinespring, Ph.D.
}

Department of Chemical Engineering

Morgantown, West Virginia

2000

Keywords: Uranium, Carbon, Nanofibers, Electrosorption, Environmental Copyright 2000 Shannon L. Stover 


\section{ABSTRACT \\ Removal of Uranium from Aqueous Wastes Using \\ Electrically Charged Carbon Nanofibers}

\section{Shannon L. Stover}

The presence of aqueous uranium wastes is a problem in the United States and their treatment/disposal is desirable. Treatment methods have been developed but result in concentration opposed to conversion to a disposable form. This technique involves recovery of uranium as a solid, providing an advantage over other methods. The technique utilizes carbon nanofibers as electrodes which successfully electrosorb uranium ions. Fibers with varying surface characteristics were evaluated in the removal process and all were determined to be equally and extremely effective. Various experimental parameters were evaluated including applied potential, $\mathrm{pH}$, and flow rate. The critical applied potential at which significant removal is achieved is between -0.3 and $-0.4 \mathrm{~V}$. Decreasing $\mathrm{pH}$ hinders the electrosorption process while increasing it enhances the process. As expected, an increase in flow rates results in decreased removal. It was determined that cyclic loading/unloading increased fiber performance and a capacity of at least $5.45 \mathrm{~g}_{\text {uranium }} / \mathrm{g}_{\text {carbon }}$ can be achieved. These results illustrate that this technique can be effectively implemented to solve current waste management problems. 


\section{DEDICATION}

This work is dedicated to Duncan,

for his companionship and steadfast devotion.

You will never comprehend the importance of your presence in my life,

you are truly a gift from God. Neither will you ever understand how much I

appreciate you staying awake and keeping my feet warm while writing.

I will always remember you waiting by the window for me to

return from my late night trips to the lab. 


\section{ACKNOWLEDGEMENTS}

I would like to express by sincere thanks to Dr. John Zondlo, my committee chairman, for his contribution to my success. He has provided advice and encouragement throughout both my graduate and undergraduate careers; however, his contribution to my technical and professional development made the completion of this thesis possible.

I would also like to thank my committee members Dr. Peter Stansberry, Dr. Charter Stinespring, and Mr. Elliot Kennel. A special thanks is extended to both Dr. Stansberry and Mr. Kennel for their help in the laboratory. I would also like to thank Dr. John Renton of the WVU Department of Geology for performing x-ray analyses of uranium compounds; Mr. Joel Harrison of NIOSH for generating SEM photographs of fiber samples; Mr. Gerry Glasgow for supplying information on the production and characterization of the carbon nanofibers; and Ms. Wei Cheng for her contribution to the attempts at FT-IR analyses.

Heartfelt appreciation is extended to my best friend, Byron, for his patience and encouragement throughout the development of this work. I am also deeply indebted to my friends, Chrystal and Seth, for maintaining my sanity over the past several months. Finally, I will be forever grateful to my family; my parents, Pam and Charlie, and my sister, Autumn, provide constant support and unconditional love. Their encouragement is greatly appreciated and all that I have achieved I owe to them.

Funding for this research was provided by a subgrant from Applied Sciences, Inc. to whom a Phase I SBIR grant was provided by the US Department of Energy. 


\section{CONTENTS}

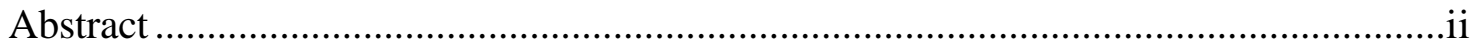

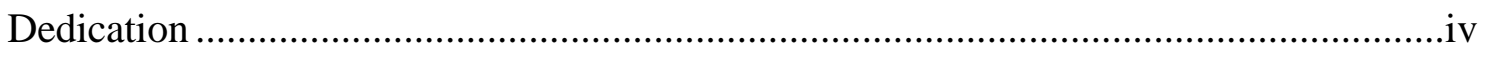

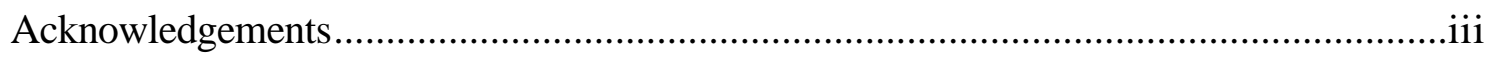

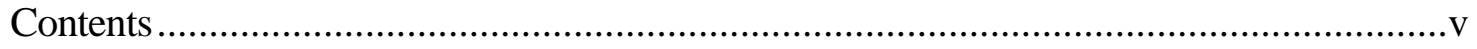

List of Tables........................................................................................................

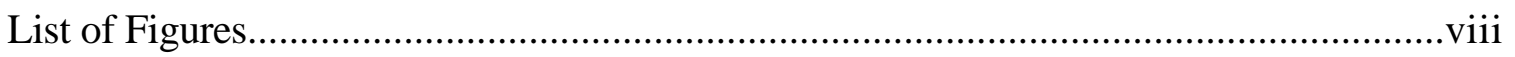

Chapter 1: Introduction and Research Scope ...........................................................

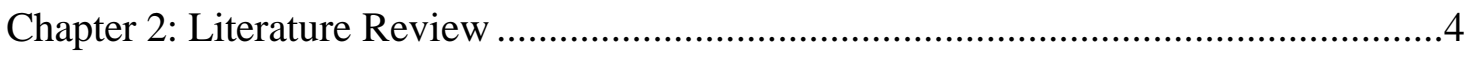

2.1 Summary of Treatment Methods Currently in Use.................................4

2.1.1 Coagulation-Filtration ...................................................

2.1.2 Lime Softening.................................................................

2.1.3 Reverse Osmosis Hyperfiltration ........................................6

2.1.4 Electrodialysis Process ......................................................6

2.1.5 Activated Alumina.............................................................

2.1.6 Carbon Adsorption ................................................................8

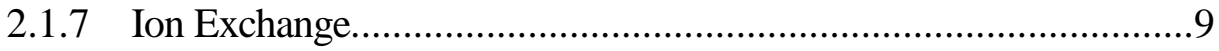

2.2 Possibility of Using Electrochemical Removal Techniques ....................11

2.2.1 Electrosorption .............................................................. 11

2.3 Related Electrosorption Techniques................................................. 14

2.3.1 Traditional Adsorption Processes ............................................14

2.3.2 Removal by Microbial Reduction...........................................17

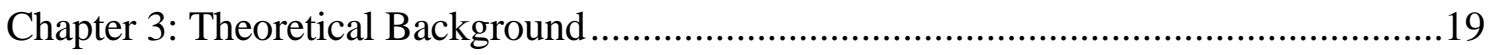

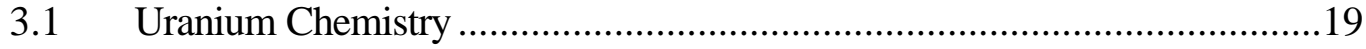

3.1.1 Properties of Uranium Compounds ......................................20

3.1.2 Uranium Ions in Solution ...................................................21

3.1.2.1 Trivalent Uranium...............................................21

3.1.2.2 Tetravalent Uranium ................................................21

3.1.2.3 Pentavalent Uranium ............................................23

3.1.2.4 Hexavalent Uranium ..........................................23 
3.1.3 Uranium Species as a Function of $\mathrm{pH}$........................................2

3.1.4 Relationship Between pH and Electrochemical Potential.............29

$3.2 \quad$ Electrochemistry................................................................................... 32

3.3 Possible Electrosorption Mechanisms.......................................................32

Chapter 4: Experimental Apparatus and Methods.............................................................34

4.1 Carbon Materials ......................................................................................34

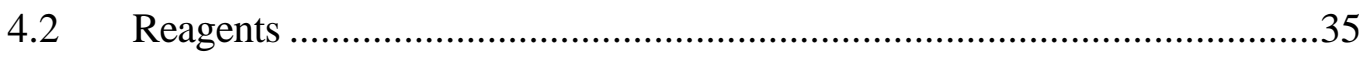

4.3 Electrolytic Cell and Fiber Loading ………………..................................35

$4.4 \quad$ Experiments and Sampling Techniques......................................................38

4.5 Analytical Methods.................................................................................

4.6 Fiber Unloading .................................................................................4

4.7 FT-IR and X-Ray Diffraction Analyses...................................................42

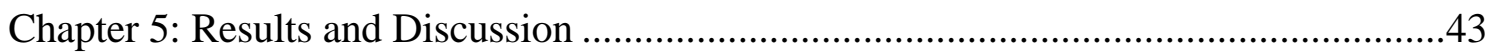

5.1 Performance Experiments ........................................................................43

5.2 Effect of Cell Potential on Fiber Performance...........................................53

5.3 Effect of Flow Rate on Fiber Performance .................................................55

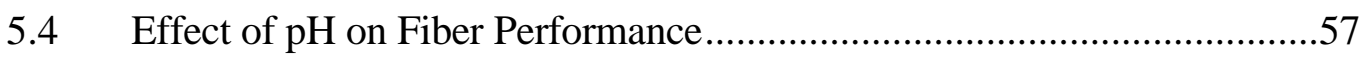

5.5 Effect of Cyclic Loading/Stripping of Fibers..............................................59

5.6 Fiber Capacity ……………………………………………………......59

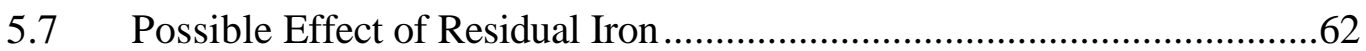

5.8 Attempt to Identify Surface Functional Groups Using FT-IR Analysis .....63

5.9 Identification of Uranium Solid By X-Ray Diffraction ...............................64

5.10 Examination of Fibers Using SEM.........................................................64

Chapter 6: Conclusions and Recommendations ........................................................67

6.1 Performance Experiments .....................................................................67

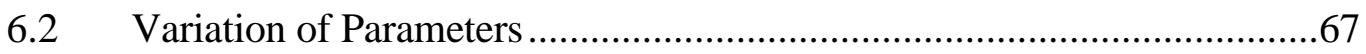

6.3 Removal Efficiency and Fiber Capacity ………………………………....68

6.4 FT-IR, X-Ray Diffraction Analysis, and SEM...........................................69

6.5 Recommendations for Future Work ........................................................70

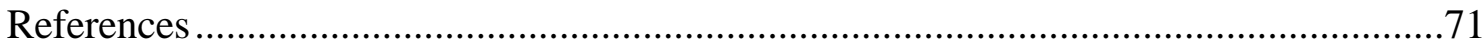

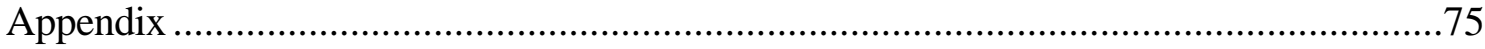




\section{LIST OF TABLES}

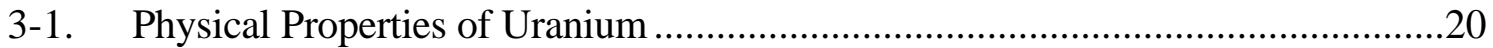

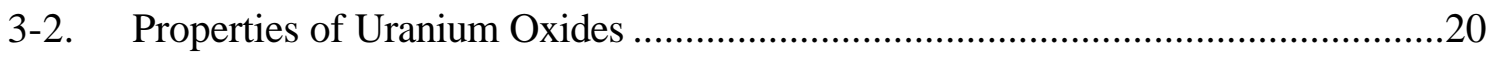

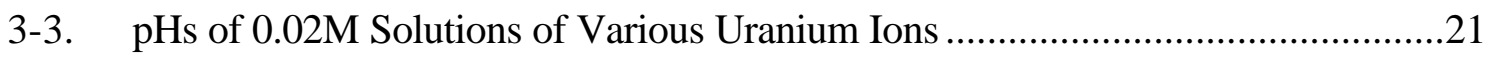

3-4. Values of the Hydrolysis Constants of $\mathrm{U}^{4+}$ at Various Temperatures ....................22

3-5. Activity Coefficients of $\mathrm{UO}_{2}{ }^{2+}$ in Uranyl Nitrate Solution ................................24

3-6. Activity Coefficients of the Uranyl Ions as a Function of Ionic Strength of the

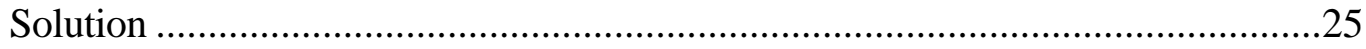

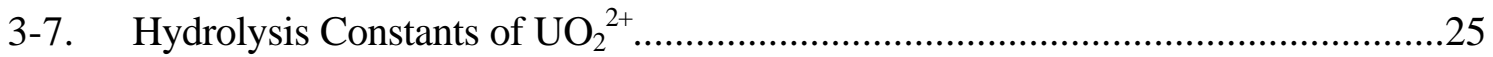

3-8. $\quad \mathrm{pH}$ at Precipitation Initiation as a Function of UO22+ Concentration in

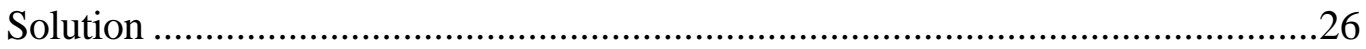

3-9. Temperature and Ionic Strength Dependence of Hydrolysis Constants of

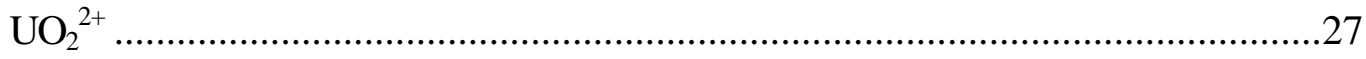

3-10. Potentials for Oxidation/Reduction Reactions of Uranium Species .....................30

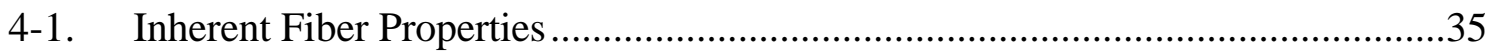




\section{LIST OF FIGURES}

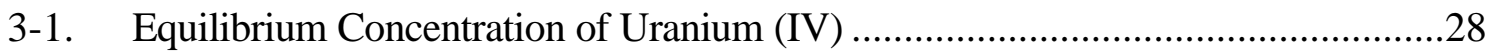

3-2. Equilibrium Concentration of Uranium (VI) ……….....................................28

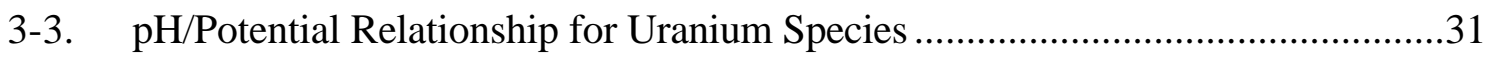

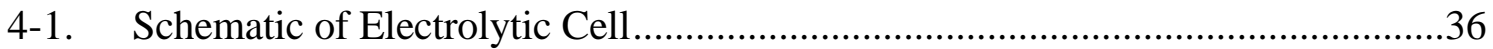

4-2. Experimental Setup Showing Potential, Voltmeter, Cell, and Peristaltic

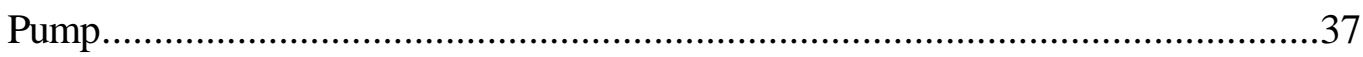

4-3. Typical Voltammogram from DPV Analysis of U(VI) ........................................40

4-4. Calibration Curve for the Concentration Range 0.0 to $5.0 \mathrm{ppm}$.............................41

4-5. Calibration Curve for the Concentration Range 5.0 to $100.0 \mathrm{ppm}$.........................41

5-1. Performance Curve for PR-1-ox400 …………….............................................44

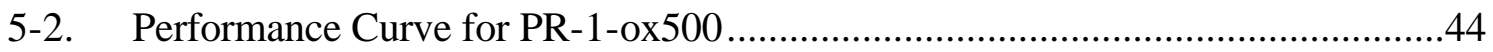

5-3. Representative Behavior of Current throughout the Performance Experiments ................................................................................................

5-4. Representative Behavior of Effluent $\mathrm{pH}$ throughout the Performance

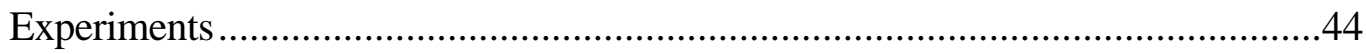

5-5. Performance Curve for PR-19-ox400 …………….........................................46

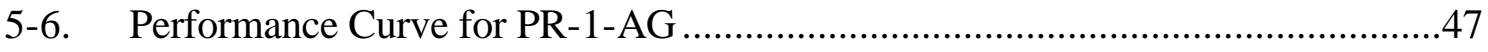

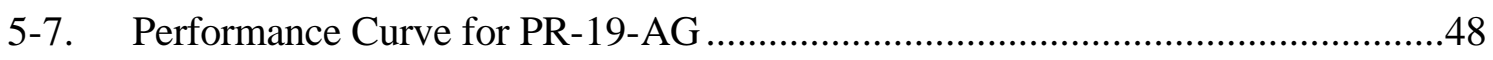

5-8. Performance Curve for PR-19-HT.....................................................................49

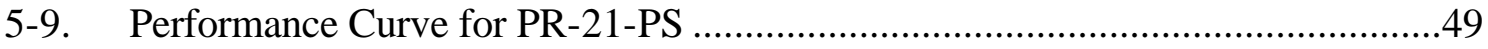

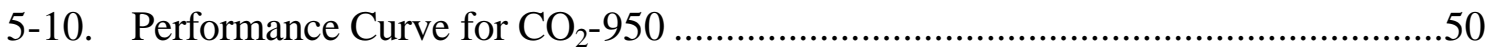

5-11. Performance Curve for PR-23-HT...................................................................50

5-12. Performance Curve for PR-24 …………………........................................

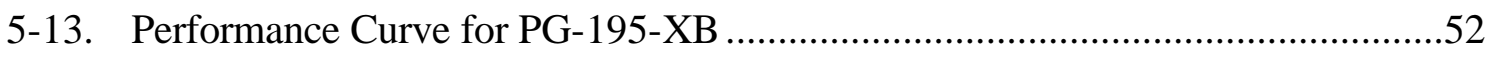

5-14. Performance Curve for Superior Graphite (BG-34) ………………………......52

5-15. Effect of Variation in Applied Potential ..........................................................54

5-16. Effect of Applied Potential on Steady-State Effluent Concentration ......................55

5-17. Effect of Variation of Flow Rate ....................................................................56

5-18. Limiting Flow Rate Determination Through Evaluation of Steady-State 


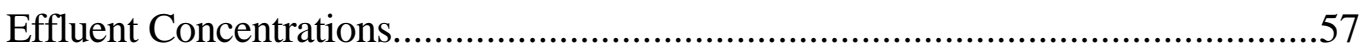

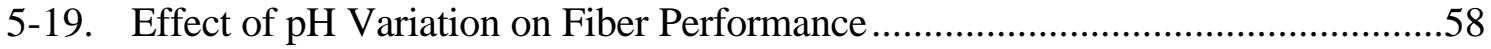

5-20. Effect of Cyclic Loading/Stripping on Fiber Performance .................................60

5-21. Evaluation of Fiber Capacity .................................................................61

5-22. Percent Residual Ash in Fiber Samples............................................................62

5-23. Results of X-Ray Diffraction Analysis ...................................................65

5-24. SEM of PR-1-AG Showing Smooth Surface.....................................................66

5-25. SEM of PR-19-HT Showing Surface Roughness Following Post-Treatment........65 


\section{CHAPTER 1}

\section{INTRODUCTION AND RESEARCH SCOPE}

Treatment and disposal of uranium wastes has become an increasing problem in the United States and worldwide since the discovery of uranium's ability to provide both power, through the operation of nuclear power plants, and protection, through the use of nuclear weapons. Several aqueous, multi-component wastes exist and it is desirable not only to treat the substances by concentrating the aqueous wastes, allowing for disposal, but also to discover a method that would allow for selective removal of contaminants, creating an avenue for recovery of these valuable materials [1].

Several treatment methods have been developed to remove metals from aqueous wastes including chemical precipitation, solvent extraction, adsorption, and ion exchange, just to name a few [2]. Although the aforementioned methods have proven useful in several applications, they often fail to reduce contaminants to below required levels, and/or are too costly to be commercially implemented. It is therefore highly desirable to establish a technique that is economical to implement, effective in reaching desired effluent concentrations, and allows for the possibility of recovery and possible sale of the actual contaminants through a selective separation process. Electrochemical treatment could be used not only to treat stored wastes but also to treat wastewater from sites that are currently generating waste.

The operation of electrolytic cells is not in itself a new treatment method and has been used for years to treat highly concentrated wastes from the electroplating, photo finishing, and mining industries; however, several problems arise when attempting to use this technique to treat large scale, low concentration streams including the small surface area of metal electrodes which are traditionally the electrodes of choice. Therefore, the development of a new type of inexpensive electrode material could provide a means by which this technique would become both effective and economical for treating large quantities of dilute waste streams.

A potential electrode material should exhibit good electrical conductivity, be chemically inert over the potential region of interest, show favorable electrochemical behavior with the anolyte(s), have a low background current, and have an easily reproducible surface. It was recently discovered that certain types of carbon materials 
including graphite, carbon paste, glassy carbon, and reticulated vitreous carbon (RVC) performed well when used as electrodes [3]. West Virginia University (WVU) previously tested carbon nanofibers supplied by a variety of sources for their effectiveness in the removal of uranium ions from a synthetic aqueous waste stream [4]. It was discovered that one particular fiber, supplied by Applied Science, Inc. (ASI), was particularly effective; however, reasons for the fiber's effectiveness and the mechanism of removal were not clearly determined. Not only were the fibers effective in removing uranium from aqueous wastes, but the uranium could also be obtained in solid form by stripping the carbon fibers. Each of these characteristics makes this technology quite unique when compared to other existing technologies. For this reason both WVU and ASI are particularly interested in pursuing this research as it could prove to be a valuable tool in both the elimination of several environmental problems and the recovery of valuable minerals.

The objective of this research project was to continue the testing previously mentioned through the analysis of additional samples of nanofibers prepared by ASI. Carbon nanofibers were prepared with various surface treatments in order to identify the optimal methods for producing effective electrosorption electrodes. The previous studies at WVU provided reason to believe that nanofibers that are mildly oxidized after growth exhibit high electrosorption affinity for uranium while very little affinity is present in the untreated fibers; however, all fibers produced and tested in this study were successful in uranium removal.

ASI prepared the nanofibers in approximate one-pound batches. This is far in excess of the requirement for individual electrodes, and allows more than adequate material for a variety of studies. Following the fabrication of the fibers, each was used to create an electrode and its efficiency in the uranium removal process was determined. The tests were carried out in an electrolytic cell composed of a working, auxiliary, and reference electrode. The cell and testing methods are described in detail later in Chapter 4. Experiments were designed to provide results that provide insight into which of the following characteristics contributed to the electrodes' performance: surface oxygen, surface area, surface energy, diameter, graphitization index, and surface PAH content.

Testing included several types of experiments to attain the above-mentioned information and was divided into two categories. The first set of experiments involved 
loading each electrode with uranium to analyze its performance as a function of time required to reduce the inlet concentration of uranium to acceptable levels. Each study was performed at least twice to ensure accuracy and reproducibility. Following this study, a select fiber was further tested to determine its absorptive capacity. An additional performance experiment was also performed and involved the cyclic loading and unloading of the fibers to identify any decrease in efficiency upon regeneration.

The second set of experiments was used to obtain further information on the mechanism that makes this technique a success. These tests included several different types of analyses. Experimental parameters including the $\mathrm{pH}$ and flow rate of the feed and the cell potential were varied to determine their effect. Identification of the solid precipitate mentioned previously was attempted through x-ray diffraction analysis of both the precipitate itself and of a nanofiber sample that was loaded with the uranium precipitate. An attempt was made to analyze the carbon nanofibers using Fourier transform infrared (FT-IR) spectroscopy to identify any surface functional groups present that may have been contributing to their effectiveness; however, these tests were unsuccessful, the reason for which is discussed in more detail later in the report. Finally, photographs were taken using a scanning electron microscope (SEM) in an attempt to identify differences in the surface characteristics of the fibers.

The results obtained from these experiments were effective in demonstrating that not only can the electrodes be reproduced and optimized, but that the potential for commercial development of this technique in the future could prove to be very valuable in the effort to restore and control the declining integrity of those sections of the world that are battling with radioactive contamination in the form of uranium pollution. 


\section{CHAPTER 2}

\section{LITERATURE REVIEW}

Uranium removal techniques are receiving attention due to the ever-increasing strictness of environmental regulations posed by the Environmental Protection Agency (EPA). In addition to becoming a problem due to its naturally occurring presence in surface and ground waters, uranium is the most prevalent radionuclide present at Department of Energy (DOE) sites. The current standards imposed by the EPA are a Maximum Contaminant Level (MCL) of $20 \mathrm{ppm}$ and a Maximum Contaminant Level Goal (MCLG) of zero [5]. Therefore, it is desirable to develop economically feasible treatment methods to achieve these goals, the progress of which is described in this chapter.

\subsection{Summary of Treatment Methods Currently in Use}

There have been several removal techniques developed in recent years and studied in laboratories and in pilot plants both across the nation and around the world. The most popular primary treatment methods to date include conventional coagulationfiltration with iron or alum, lime softening using varying amounts of $\mathrm{Ca}(\mathrm{OH})_{2}$ and $\mathrm{MgCO}_{3}$, ion exchange by cation or anion resin, reverse osmosis hyperfiltration, electrodialysis, and activated carbon or activated alumina adsorption. The first four methods have proven to be both effective and economically feasible for uranium removal from drinking water, and EPA considers them to be the best available technologies (BATs) [5].

\subsubsection{Coagulation-Filtration}

The coagulation-filtration process involves the addition of a chemical substance, typically iron or alum, which attracts uranium ions and/or complexes, resulting in larger particles that are then easily filterable. A significant amount of laboratory testing has been completed in this area and impressive removal efficiencies have been realized [6]. These efficiencies are dependent upon the coagulant dosage and the final $\mathrm{pH}$ of the solution. Testing has been conducted on samples of pond water containing 83-ppb uranium in the form of $\mathrm{UO}_{2}\left(\mathrm{CO}_{3}\right)_{2}{ }^{2-}$ and $\mathrm{UO}_{2}\left(\mathrm{CO}_{3}\right)_{3}{ }^{4}$, common species that are typical of 
most carbonate-dominated surface and well waters. Upon the addition of $25 \mathrm{mg} / \mathrm{L}$ of aluminum sulfate or ferric sulfate to the waste, removal efficiencies of more than $85 \%$ can be achieved. Previous tests were successful at pHs of both 6 and 10; however, the removal decreases significantly at pHs both below 6 and above 10. Success at a pH of 6 is due to the attraction of the uncharged $\mathrm{UO}_{2} \mathrm{CO}_{3}$ complex (the dominant uranyl complex at this $\mathrm{pH}$ ) to the relatively uncharged aluminum or iron oxyhydroxide surface.

At $\mathrm{pH} 10$ it is believed that $\mathrm{CaCO}_{3}$ precipitation caused a decrease in the carbonate concentration that results in the formation of $\left(\mathrm{UO}_{2}\right)_{3}(\mathrm{OH})_{5}{ }^{+}$complex, which in turn is attracted to the negatively charged coagulant surface. Below a $\mathrm{pH}$ of 6 the coagulant does not form an appreciable amount of floc while at pHs above 10 the precipitant becomes increasing soluble. Both of these phenomenon result in a decrease in removal efficiency. These results have also been duplicated, reinforcing the finding that uranium can be efficiently removed by coagulation-filtration techniques [7]. Although this technique is effective, continuous costs are incurred due to the required chemical addition. The technique described also requires a settling time prior to filtration that results in the need for large storage tanks and a batch-type process. The process could possibly be run in a continuous manner but would require large continuously stirred tank reactors, increasing the capital investment.

\subsubsection{Lime Softening}

It has been known for some time that uranium can be removed through precipitation/filtration by significantly increasing the $\mathrm{pH}$ of the solution. It has been determined through testing that upon addition of lime $(50-250 \mathrm{mg} / \mathrm{L}), \mathrm{pHs}$ can be increased to 11.5 , resulting in 85 to $90 \%$ removal efficiencies [6]. Tests have been completed using both lime and a mixture of lime and magnesium to determine if the presence of magnesium enhances the removal of uranium. It was determined that in the absence of magnesium, little difference is observed in the removal efficiencies over the $\mathrm{pH}$ range of 10.6 to 11.5; however, the presence of magnesium does result in a relationship between $\mathrm{pH}$ and amount of uranium removed. It was reported that at $\mathrm{pHs}$ between 9.8 and 10.6, the addition of $\mathrm{MgCO}_{3}$ reduced the effectiveness of the lime while at $\mathrm{pHs}$ greater than 10.6, uranium removal increased with increasing amounts of $\mathrm{MgCO}_{3}$. It was established that at $\mathrm{pHs}$ between 8.5 and 10.6, the calcium and magnesium 
carbonate precipitates removed only 10 to $30 \%$ of the uranium while at pHs above 10.6 , the addition of magnesium raised removal efficiencies to between 93 and 99\%. It was concluded that the presence of $\mathrm{Mg}(\mathrm{OH})_{2}$ precipitates at $\mathrm{pHs}$ greater than 10.6 significantly increases uranium removal via lime softening. Despite the success of this technique it too, like coagulation-filtration, incurs a continuing cost for the addition of lime and possibly other chemicals such as $\mathrm{MgCO}_{3}$ added to enhance performance. This technique would also have to be performed in a batch-type process, proving it to be unfeasible for large volume, low concentration wastes. Also like coagulation-filtration, if this process were to be run in a continuous manner, large reactors would be required.

\subsubsection{Reverse Osmosis Hyperfiltration}

The reverse osmosis ( $\mathrm{RO})$ process is typically implemented in the desalting of municipal water and is a pressure-driven transport process that utilizes a membrane to retain unwanted ions while allowing water to pass. The process involves separating the salt (or other ions) by maintaining the pressure of the feed above that of the opposing osmotic pressure of the ionic solution against the semipermeable membrane. This technique has proven to be $99 \%$ effective in removing uranium from a Florida groundwater contaminated with $300 \mathrm{ppb}$ uranium [8]. The effectiveness of this technique in the removal of uranium is not surprising due to the fact that the uranium carbonate complexes $\left(\mathrm{UO}_{2}\left(\mathrm{CO}_{3}\right)_{2}{ }^{2-}\right.$ and $\left.\mathrm{UO}_{2}\left(\mathrm{CO}_{3}\right)_{3}{ }^{4-}\right)$ present in natural waters are very large and highly charged. This technique is typically operated in a continuous-type process, making it more appealing than previously described techniques in the treatment of large volumes of aqueous wastes. However, feed rates are usually slow in order to allow the liquid to pass through the membranes, resulting in the need for several RO tubes operated in parallel. In addition to the significant capital cost, the operational costs due to pumping to achieve the required pressure gradient across the membrane also make this process unattractive.

\subsubsection{Electrodialysis Process}

Electrodialysis (ED) is another widely applied desalting technique that is used to treat brackish water for potable use or to desalt and concentrate effluents for reuse. ED 
involves an electrochemical separation process in which ions are driven through anionand cation- selective membranes from a less concentrated to a more concentrated solution as a result of the flow of direct electric current. The electrodialysis reversal (EDR) process now in common use is a refinement of the ED process, in which depleting and concentrating channels are switched and the polarity of the electrodes is reversed typically four times per hour to ionically backflush the membranes in order to minimize scaling and fouling [9].

A recent study in Chimney Hill, Texas, demonstrated that ED can be used to effectively treat groundwater contaminated with uranium [9]. It was determined that by using ED, uranium removal efficiencies of more than $95 \%$ can be achieved when treating water containing $120 \mathrm{ppb}$ uranium during a continuous 28-day test. However, it was later determined that the uranium removed was not removed by ion transport as is typical with ED processes, but by accumulation of uranium in the anion membranes of the ED stack. Therefore, this process is not desirable when typical anion exchange resins are capable of achieving the same effects while utilizing a less complicated process.

\subsubsection{Activated Alumina}

It has been shown that activated alumina when placed in a packed bed can be used to remove uranium from groundwater [10],[11]. EPA's Drinking Water Research Division Lab conducted testing and determined that removal efficiencies of $99 \%$ can be attained when using feed water containing 273 to $432 \mathrm{ppb}$ uranium; however, the length of the run was only between 1,600 to 2,000 bed volumes (BV) during the six cycles tested. An additional study also showed that the activated alumina was effective in removing uranium up to $2,500 \mathrm{BV}$ at a $\mathrm{pH}$ of 8 . However, the experiment was halted due to an increase in head loss after two or three regenerations with $10 \% \mathrm{NaCl}$.

Although the activated alumina columns are successful in removing uranium down to $1 \mathrm{ppb}$, the columns exhaust quickly and require frequent regeneration. As stated above, the regeneration process results in an increase in pressure drop across the column. When coupled, these problems make the use of activated alumina an unattractive technique. In addition to the abovementioned operational difficulties, the implementation of this technique, as with other adsorption/regeneration processes, results in simply 
concentrating the waste which must then be treated in some other way to obtain a solid form, increasing the overall cost of the process as a whole.

\subsubsection{Carbon Adsorption}

Granular activated carbon (GAC) has also been tested to determine its effectiveness in the uranium removal process. Tests were conducted utilizing two small, full-scale GAC columns to treat a feed containing 26 to $101 \mathrm{ppb}$ uranium, reducing the effluent concentration to below 1 ppb [12]. The columns were effective for three months at which time they reached breakthrough. The effluent concentration continued to increase after breakthrough until it eventually surpassed the influent concentration. Unfortunately, the experiment was not well documented and exact bed volume throughputs were not recorded, making the results difficult to interpret.

Later testing involved the evaluation of four different types of GAC including Calgon APA, F-400, and Barnebey-Cheney CK3421 and 1002 [9]. The GAC samples were tested at various pHs using 1-in. diameter glass columns and a feed contaminated with 67 to $90 \mathrm{ppb}$ uranium. At $\mathrm{pHs}$ ranging from 7.8 to 8.2, none of the samples removed more than $5 \%$ of the uranium from the feed. Later experiments involved lowering the $\mathrm{pH}$ to 5.8 in a successful attempt at improved removal. It is believed that this increase in removal is due to the presence of the uncharged uranium carbonate complex, $\mathrm{UO}_{2} \mathrm{CO}_{3}$, the predominant species at a $\mathrm{pH}$ of 5.8, which is readily removed by adsorption onto GAC. It should be noted however, that although the GAC became more effective, its capacity is still far below that of anion exchange resins. The effluent uranium concentration from the GAC columns increased to $10 \mathrm{ppb}$ at between 800 and 5,000 BV and $20 \mathrm{ppb}$ after 2,500 to 8,500 BV, depending on the type of GAC being used.

Overall, GAC demonstrates not only a limited capacity but also a strong $\mathrm{pH}$ dependence. In a later attempt to reproduce these tests, it was reported that $95 \%$ uranium removal was achieved at pHs less than 6.4 and less than $1 \%$ removal at pHs higher than 9.1 [13]. The $\mathrm{pH}$ dependence of GAC clearly demonstrates the importance of uranium complexes in the feed water. Although GAC columns can be used to treat uranium to a certain extent, the limited capacity and therefore increased regeneration frequency result in a process that is economically inferior to anion exchange, which is discussed in the following section. 


\subsubsection{Ion Exchange}

Ion exchange has proven to be the most effective and economical treatment technique, therefore making it the most popular. Both cation and anion exchange resins have been used for uranium removal; however, the anion exchange resin has proven to achieve removal efficiencies superior to those of cation resins. Several cationic resins have been tested including $\mathrm{H}^{+}, \mathrm{Na}^{+}$, and $\mathrm{Ca}^{2+}$ forms [13]. The hydrogen form cationic resin resulted in 93 to $97 \%$ uranium removal with the effluent $\mathrm{pH}$ equal to 3.5. Both the calcium and sodium forms were unsuccessful at a $\mathrm{pH}$ of 8.2 ; however, at a $\mathrm{pH}$ of 7 , the sodium-form resin achieved $85 \%$ removal while the calcium form was still unsuccessful. The calcium-form resin did not begin to remove uranium until a $\mathrm{pH}$ of 5.6 was utilized. The removal efficiencies continued to increase with decreasing $\mathrm{pH}$. By the time a $\mathrm{pH}$ of 4 was reached, removal efficiencies of 60 to $65 \%$ were realized. The sodium-form resin maintained a removal efficiency of $70 \%$ at all lower $\mathrm{pH}$ values.

The abovementioned results demonstrate the strong dependence of uranium removal on both the $\mathrm{pH}$ of the feed and the form of the resin, indicating the importance of the uranium speciation in solution. The varying efficiencies of the resin forms are related to the selection sequence of the cations. Although the cation resins are considered to be somewhat effective, the requirements for a low feed $\mathrm{pH}$ and the low removal efficiencies indicate that the process is not feasible for treatment of drinking water.

Anionic resins result in much higher removal efficiencies when used to treat contaminated water. It has been suggested that anionic resin treatment would be the only cost effective treatment method for small community water supplies [12]. Both benchand pilot-scale studies have shown that the strong-base anionic resins exhibit very high capacity (up to 60,000 BVs) for the removal of the uranyl carbonate complexes including $\mathrm{UO}_{2}\left(\mathrm{CO}_{3}\right)_{2}{ }^{2-}$ and $\mathrm{UO}_{2}\left(\mathrm{CO}_{3}\right)_{3}{ }^{4-}$. One test, using a feed of water containing 22 to $104 \mathrm{ppb}$ uranium, resulted in treating 8,000 to 60,000 bed volumes before exceeding $1.0 \mathrm{ppb}$ in the effluent [14]. Another study using anionic resins also proved successful and achieved $70 \%$ removal after a 4,000 BV throughput [13]. Additional studies using real waste samples containing $300 \mathrm{ppb}$ uranium resulted in successfully treating over 9,000 bed volumes before uranium was detected in the effluent [11]. A final study involved analyzing two forms of resin including Dowex $21 \mathrm{~K}$ and Ionac 641, which were operated 
to $17,400 \mathrm{BV}$ and $31,300 \mathrm{BV}$, and still removed $95 \%$ and $90 \%$, respectively, of the total uranium in the feed [10]. The results of these tests indicate that anionic resins display a high selectivity for the charged uranyl carbonate complexes commonly found in groundwater.

Due to the excellent performance of anionic exchange resins and the ability to easily regenerate the materials, this technique has become the EPA's treatment of choice in the remediation of uranium laden aqueous wastes. The decommissioning and treatment of a weapons grade production facility located in Fernald, Ohio illustrates one example of the effectiveness of anionic exchange resins. The US Department of Energy and Flour Daniel are each contributing to the clean up of the site, which involves contaminated soils and structures, resulting in contaminated surface and subsurface waters. The subsurface contamination involves the contamination of a small portion of the Great Miami Aquifer, one of the largest sources of drinking water in the country. The DOE has implemented a pump-and-treat system to treat the contaminated section of the aquifer and inject the treated water back into the aquifer. The process involves the treatment of 2,900 gpm of water contaminated with between 60 to $1,000 \mathrm{ppb}$ uranium in the form of complex uranium carbonate ions. The waste is treated using an anionic exchange resin that successfully reduces the uranium concentration to below acceptable limits (i.e., 20ppb).

The columns are regenerated approximately once a month, producing concentrated $(300 \mathrm{ppm} \mathrm{U}$ ) brine solution that must then be treated. The $\mathrm{pH}$ of the brine is increased through the addition of lime and the uranium is precipitated and recovered through filtration. The supernatant liquid, which contains small concentrations of uranium, is recycled to the front of the process and bled slowly into the fresh waste entering the ion exchange columns.

Although this technique is very effective and combines the best features of two methods, ion exchange and precipitation/filtration, a treatment process that achieves the same results in one step would be desirable. A successful process, in which uranium is removed from liquids and recovered in a solid form, without the addition of chemicals to adjust $\mathrm{pH}$, would prove to be ideal. 


\subsection{Possibility of Utilizing Electrochemical Removal Techniques}

Treatment of aqueous wastes containing metals by electrochemical reduction is an attractive possibility due to the economic advantage of recovering valuable metals [1]. However, while this technique is effective for several metals including copper, lead, cadmium, and nickel, it is not useful for uranium. The reduction potential required to reduce the uranyl ion $\left(\mathrm{UO}_{2}^{2+}\right)$ to elemental uranium is between $-1.79 \mathrm{~V}(\mathrm{dc})$ and $-2.11 \mathrm{~V}$ (relative to a $\mathrm{Ag} / \mathrm{AgCl}$ electrode), which is significantly more negative than the reduction potential of water, which is $-0.83 \mathrm{~V}(\mathrm{dc})$ [15]. It is for this reason that the direct reduction via electrodeposition of uranium cannot be accomplished and alternative electrochemical methods such as electrosorption are being investigated.

\subsubsection{Electrosorption}

One cousin to electrodeposition, known as electroadsorption or simply electrosorption, involves the adsorption of $\mathrm{UO}_{2}^{2+}$ onto a negatively charged electrode surface. The technique does not involve the reduction of uranium to its elemental state, eliminating the aforementioned difficulties associated with electrodeposition. The negative potential placed on the electrode is significantly higher than the natural negative surface charge formed as a result of the dissociation of oxygen functional groups present on the surface. This technique enhances the adsorption capacity of the electrode and makes it possible to take advantage of the increased surface areas and electrical conductivity of some forms of carbon and graphite. It is possible that the success of this technique could result in a minimally polluting, energy-efficient, and potentially effective alternative to current treatment methods [16].

Electrosorption is a technique in which low concentration aqueous wastes can be treated and the wastes accumulated in a solid form as opposed to a concentrated aqueous one. Upon researching this technique, it became apparent that there are no parallel investigations in this area based on publications in past or recent literature. It appears that the WVU/ASI group may have conducted the only research in this area to date, which has paved the way for the work presented herein [4].

Previous studies at WVU involved the use of carbon nanofibers produced using an iron catalyst [4]. Two fibers were tested, one which was tested "as-grown" with no post fabrication treatment and another which was oxidized following fabrication to 
increase the amount of oxygen-containing functional groups of the surface. Through experiments utilizing a small electrolytic cell, a flow rate of $0.7 \mathrm{~mL} / \mathrm{min}$, and a feed concentration of $100 \mathrm{ppm}$ uranium in the form of $\mathrm{UO}_{2}{ }^{2+}$ (in $0.1 \mathrm{M} \mathrm{KNO} 3$ to increase the ionic strength of the solution), it was determined that the post-oxidized fibers were significantly more effective than the unoxidized fibers. Additional studies were conducted to determine the effects of altering $\mathrm{pH}$, flow rate, and applied potential. Results were affected by all three factors. The process is ineffective at pHs below 3.5 while it is enhanced at all pHs above 3.5. As expected, the removal efficiency decreased with increasing flow rate. Finally, a unique dependence on the applied potential was established. The fibers were ineffective at potentials less negative than $-0.45 \mathrm{~V}$; however, upon achieving the potential of $-0.45 \mathrm{~V}$, the increase in fiber performance was significant and continued to increase with increasing potential. Upon reversing the potential, the uranium was obtained in a solid form that has yet to be identified.

Although no information on electrosorption of uranium is available, aside from the previous research at WVU, research on the electrosorption of other ions has been published. One example involves the electrosorption of hexavalent chromium ions (present as $\mathrm{HCrO}_{4}^{-}, \mathrm{CrO}_{4}^{2-}$, and $\mathrm{Cr}_{2} \mathrm{O}_{7}^{2-}$ ) from groundwater through the use of carbon aerogel electrodes [16]. The electrodes have a high surface area, typically between 400 and $1100 \mathrm{~m}^{2} / \mathrm{g}$, and an exceptionally low electrical resistivity (less than or equal to 40 mÙ. $\mathrm{cm}$ ). Upon applying a potential to the column, it was discovered that the ions were removed from the electrolyte and electrosorbed onto the electrode surface. Influent concentrations were reduced from $35 \mathrm{ppm}$ to $2 \mathrm{ppm}$, well below the acceptable level of $11 \mathrm{ppm}$, as per surface water regulations. It is believed that the $\operatorname{Cr}(\mathrm{VI})$ separation was not the result of simple double-layer charging but chemisorption, a process reversed by cathodic polarization.

The electrosorption technique has also proven to be successful in the removal of lithium ions from aqueous solutions using chemically and physically activated carbons [17]. The performance of the carbon electrodes was a strict function of their physicochemical properties including pore volume, pore size distribution, and surface area. Testing included runs during which electrochemical polarization was present and runs where it was not. Results indicated that the cathodic treatment of the activated carbons significantly enhanced the adsorption of the lithium ions. 
Another test has been conducted that involves both the use of electrosorption and electrodialysis using an ion exchange resin [18]. The technique was tested for its effectiveness in removing $\mathrm{Ni}^{2+}$ and $\mathrm{Cu}^{2+}$ from synthetic wastes that were designed to imitate electroplating effluents. The tests involved placement of 5.0 grams of an ion exchange resin into the desalination compartment of an electrodialysis cell containing a $10 \mathrm{~cm}^{2}$ membrane. The feed contained $10 \mathrm{mg}$-eq $/ \mathrm{L} \mathrm{NaCl}$ and a metal ion $\left(\mathrm{Cu}^{2+}\right.$ or $\left.\mathrm{Ni}^{2+}\right)$ to other ion $\left(\mathrm{Na}^{+}\right)$ratio of $3: 1$. The $\mathrm{pH}$ and linear flow rate of the feed were 5 and $0.1 \mathrm{~cm} / \mathrm{s}$, respectively. Tests were conducted both with and without the presence of an electric current $\left(10 \mathrm{~mA} / \mathrm{cm}^{2}\right)$. Ion removal in the presence of the electrical current was found to be six times that of the experiment with the absence of current. The increase in removal efficiency was attributed to electrochemical reactions taking place in the resin/solution boundary layer that resulted in the formation of insoluble metal hydroxides. It should also be noted that the technique was more effective for the treatment of $\mathrm{Cu}^{2+}$ ions than for $\mathrm{Ni}^{2+}$ ions. Although this technique appears somewhat promising, it has not yet been proven effective for the treatment of uranium contaminants.

Tests have also been conducted on the removal of organic compounds from aqueous solutions using electrosorption onto GAC [19],[20],[21]. These studies include the adsorption and electrosorption of chloroform onto three types of GAC. The results are dependent upon operating parameters, including applied potential, temperature, $\mathrm{pH}$, contaminant concentration, and chemical properties of the GAC. It was determined that an increase in the negative potential, increases in initial chloroform concentration, and decreases in temperature resulted in an enhanced affinity for chloroform while the imposition of a positive potential and neutral $\mathrm{pH}$ values inhibited sorption. Although previous studies have shown GAC to be inferior in uranium removal, it is undetermined whether the presence of an applied potential would increase performance capabilities.

The abovementioned studies, in conjunction with previous testing conducted at WVU, provide significant reason to believe that electrosorption-type technologies can be developed and implemented for uranium removal. The technique would provide uranium treatment that is economically competitive with treatment using anionic exchange resins; however, proposed electrosorption techniques result in the acquisition of uranium from solution in a solid form, eliminating the need for post treatment techniques following 
regeneration. The implementation of this process would provide an economical advantage to other removal methods and also fewer process complications.

\subsection{Related Electrosorption Techniques}

As stated previously, little information is available on the treatment of uranium using electrosorption. However, techniques related to this work have been in practice for years. Because electrosorption is an enhanced adsorption process, such adsorption

processes are of interest. Although this technique was mentioned previously, a more in depth discussion is presented below. Also, because the electrosorption mechanism is not well understood, treatment methods which involve reduction and hence precipitation of the uranium ion are also included as they could provide future insight into the mechanism behind the uranium electrosorption phenomenon.

\subsubsection{Traditional Adsorption Processes}

Both natural and synthetic adsorbents are commonly used as sorbents in uranium treatment including, but not limited to, zeolites, titanium oxide, clays, polymeric materials, ion-exchange resins, iron nodules, and microorganisms. A summary of the results obtained when utilizing these various materials are presented below.

Experiments have been conducted using HEU-type zeolite crystals in the sodium form placed in batch reactors to adsorb uranium from a 50 to $20,000 \mathrm{ppm}$ feed [22]. The crystals were successful and loadings of up to $11.68 \mathrm{mg}$ uranium $/ g_{\text {zeolite }}$ were realized. It was also determined that removal efficiencies were higher for concentrations below 100 ppm. The performance of the material is attributed to a double sorption processes including ion-exchange adsorption and surface precipitation, taking place both on the surface and throughout the zeolite crystals. The process is $\mathrm{pH}$ dependent, exhibiting a stronger affinity for uranium removal at lower $\mathrm{pHs}$.

A new polymeric adsorbent has been developed and demonstrated in successfully removing uranium [23]. The material contains both hydrophilic (resulting in swelling when placed in water) and amidoxime groups (for chelating with uranyl ions). The adsorbent is created by initially placing cyano $(\mathrm{CN})$ groups on the surface and converting them to amidoxime groups through reaction with an aqueous hydroxylamine solution at a molar ratio of $1.25\left(\mathrm{NH}_{2} \mathrm{OH}: \mathrm{CN}\right)$ for three to four days. The adsorbent has demonstrated 
a very high affinity for uranium and is stable in aqueous environments.

Several naturally occurring substances have also been tested for their effectiveness in treating uranium. Clays have been used for several years in ion exchange applications and have recently been tested for their effectiveness in uranium removal [24]. It was determined that the performance of these clays was not only a function of $\mathrm{pH}$ of the feed solution, but also of the concentration of humic substances and the clay-tosolution ratio. The presence of humic substances enhances uranium adsorption at low $\mathrm{pH}$ due to the formation of a clay-humate complex.

When considering natural materials, the use of iron nodules to treat uranium is worth mentioning [25]. The iron nodules, which have proven effective in scavenging uranium from groundwater, have a high capacity for uranium uptake. Experiments show that a uranium enrichment of $8 \%$ (by weight) can be achieved, much higher than that of other forms of iron including fissure fillings and clay coatings. The mechanism is believed to involve an initial adsorption step followed by precipitation.

In several cases of environmental pollution, high ionic strengths and high $\mathrm{pHs}$ are present in conjunction with uranium pollution such as in the case of storage tank liquids and leachates from vitrified, saltstone, and grouted waste forms. Studies have been completed on the effect of these conditions on the mechanism of treatment methods involving adsorption onto natural sediments containing carbonate mineral phases [26]. It was determined that neither the concentration of uranium nor the ionic strength affect the adsorption mechanism; however, removal efficiencies greatly increased when the $\mathrm{pH}$ was increased from 8.3 to 9.3 . When the $\mathrm{pH}$ surpassed 10.3, precipitation of uranyl solids occurred causing removal efficiencies to increase dramatically but due to precipitation rather than adsorption; and as stated previously, precipitation is a costly process for large quantities of low concentration wastes due to the required chemical addition and storage requirements.

The above-mentioned studies involved the removal of uranium from aqueous wastes where other contaminants were not present; however, several studies have also been completed that involve the removal of uranium in the presence of other contaminants. One study involved the removal of uranyl ions from spent nuclear fuel [27]. An innovative anion exchange resin (AR-01) was utilized. The material is composed of a resin embedded in silica beads with benzimidazole functional groups 
present on the surface. The majority of fission products including $\mathrm{Cs}(\mathrm{I}), \mathrm{Sr}(\mathrm{II}), \mathrm{Mo}(\mathrm{VI})$, $\mathrm{Rh}$ (III) and trivalent rare earth metals were immune to adsorption while $\mathrm{Ce}(\mathrm{IV})$ was strongly adsorbed. It should be noted, however, that Ce(IV) was eventually reduced to $\mathrm{Ce}(\mathrm{III})$ by the resin, a non-adsorptive form. Zirconium (IV) also presented weak adsorption and partially mixed with $\mathrm{U}(\mathrm{VI})$. Both $\mathrm{Ru}(\mathrm{III})$ (in the form of anionic nitrosylnitrato-complexes) and $\mathrm{Pd}(\mathrm{II})$ exhibited strong adsorption.

Several types of bacteria have also been tested for their effectiveness in the uranium adsorption process. One type of bacteria, scenedesmus obliquus 34, was found to exhibit an energy independent sorption of uranium, even in the presence of other metals [28]. These metals included $\mathrm{Cu}^{2+}, \mathrm{Ni}^{2+}, \mathrm{Zn}^{2+}, \mathrm{Cd}^{2+}$, and $\mathrm{Mn}^{2+}$, each of which competed only slightly with the uptake of uranyl ions. A maximum capacity of 75 $\mathrm{mg}_{\text {uranium }} / \mathrm{g}_{\text {sorbent }}$ (dry weight) was achieved and the results could be modeled using the Freundlich adsorption isotherm. Increases in electrolyte concentrations increased the affinity for uranium sorption while pretreatment of the cells with $\mathrm{NaOH}, \mathrm{NaCl}$, ethanol, or heat resulted in only a slight decrease. Treatment of the bacteria with a buffer of $\mathrm{pH} 4$ results in desorption. The uranium uptake using this substance is believed to be attributed to active groups or capillary action in the cell wall capturing the uranium.

An immobilized biomass known as Rhizopus arrhizus has also been tested for its ability to adsorb uranium [29]. Tests were conducted using both synthetic and industrial wastes. It was discovered that when using influents with concentrations at or below 500 ppm, effluent concentrations of as low as $1 \mathrm{ppb}$ were obtained. Breakthrough of the column began at 57 bed volumes and continued through 76 bed volumes. It is also possible to regenerate the biomass and obtain highly concentrated solutions of uranium through elution. Use of synthetic uranyl nitrate solutions resulted in no deterioration of the biomass performance over twelve successive sorption-elution cycles; however, treatment of mine leachate solutions resulted in an $18 \%$ reduction in performance after only four cycles. It should be noted that the presence of additional ions, particularly aluminum, hinders the effectiveness of the technique.

Another immobilized biomass, Citrobacter, has also been studied for its use in treating acidic uranium drainage waters [30]. Samples of the acidic solutions containing 35 ppm uranium were obtained from the National Uranium Enterprise (ENUSA, Spain) and were treated by the biomass. The samples were supplemented with 5-mM glycero-2- 
phosphate and adjusted to a $\mathrm{pH}$ of 4.5. The biomass was successful in removing up to $50 \%$ of the uranium by maintaining a residence time of 1.4 hours (resulting in a flow rate of $50 \mathrm{~mL} / \mathrm{h}$ ). Although the technique is effective, the substrate used is expensive, making the process economically unfeasible. A more feasible substrate has yet to be identified.

Brewery yeast has also proven successful in the removal of uranium from aqueous wastes in a process that combines biosorption and precipitation [31]. Both unwashed and washed biomass samples were evaluated. Testing of the unwashed yeast resulted in a maximum capacity of $360 \mathrm{mg}_{\text {uranium }} / \mathrm{g}_{\text {sorbent }}$ (dry weight). It was determined that washing the yeast reduced the capacity to $150 \mathrm{mg}_{\text {uranium }} / \mathrm{g}_{\text {sorbent }}$. An additional experiment involved the retention of the unwashed biomass by a semi-permeable membrane. It was discovered that $40 \%$ of the uranium present precipitated outside the membrane, indicating that a significant portion of the uranium removal was due to precipitation induced by low molecular weight compounds loosely associated with the biomass.

Another group of immobilized biomass products has been analyzed using several different polymers as a binder material [32]. These polymers included calcium alginate, polyacrylamide, polysulfone, and polyurethane. Polyurethane-based materials were determined to be superior to the other candidates and production of pseudomonas aeruginosa CSU in the form of spherical beads of uniform size has already been accomplished at the pilot plant scale. The immobilized biomass was evaluated using a batch sorption isotherm approach including both a stirred-tank approach and continuous loading/elution in an up-flow, packed-bed column. Breakthrough results indicate that $P$. aeruginosa CSU is effective for removal of uranium from acidic, low-concentration

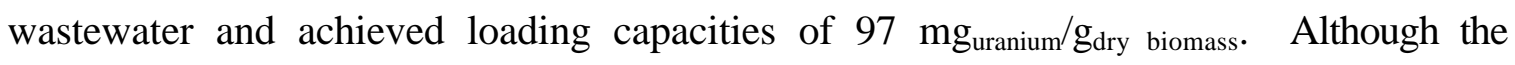
technique is effective, it takes over an hour to become so.

\subsubsection{Removal by Microbial Reduction}

As stated previously, the electrosorption mechanism is not fully understood and it is possible that a reduction, although not to the elemental state, of the uranyl ion at the surface of the electrode plays an important role. Biological reduction is therefore also worth mentioning as it has been effective in the reduction and precipitation of uranyl ions. Despite the success of these techniques, skeptics claim that the reduction is the result of an abiological reaction with sulfide, hydrogen, or organic compounds [33]. 
There has been much discussion that the microorganisms play an indirect role by producing reduced compounds that are then used to reduce $\mathrm{U}(\mathrm{VI})$ in an abiological reaction or that cell walls provide a surface for abiological reduction. Despite these criticisms, work continues in this area and is summarized below.

An initial study determined that Fe(III)-reducing organisms obtain energy for growth from electron transport to U(VI) [33]. This type of reduction can occur much faster than typical reduction techniques. The specifics of this mechanism may explain the deposition of uranium in aquatic sediments and aquifers and is suggested as a biological technique for the remediation of uranium in the environment.

Following initial studies, several more tests were completed on the potential use of biological techniques to treat uranium. One study suggested that sulfate-reducing microorganisms may contribute to the reduction of U(VI) in sediments [34]. The experiments involved the reduction of U(VI) in the presence of washed cells of sulfategrown Desulfovibrio desulfuricans in a bicarbonate buffer using lactate or $\mathrm{H}_{2}$ as an electron donor, without which no reduction occurred. Applying heat prior to reduction also inhibited treatment due to termination of the cells. However, exposure to air did not effect $D$. desulfuricans' ability to reduce U(VI). Attempts were made to grow the bacteria using $\mathrm{U}(\mathrm{VI})$ as the electron acceptor but were unsuccessful.

Additional studies were conducted on microbial reduction of U(VI) in an attempt to describe the kinetics of the technique [35]. A pure culture of Shewanella alga strain BrY was used to reduce $\mathrm{U}(\mathrm{VI})$ under non-growth conditions where lactate was used as the electron donor. Initial U(VI) concentrations ranged from 13 to 1,680 ìmol/L. Reduction rates were measured and used to determine the maximum specific U(VI) reduction rate (2.37 ìmole $-\mathrm{U}(\mathrm{VI}) /(\mathrm{mg}$ biomass $\cdot \mathrm{h}))$ and the Monod half-saturation coefficient (132 ì-U(VI)). The reduction of $\mathrm{U}(\mathrm{VI})$ was maintained at a minimum of $60 \%$ of this rate throughout at least 80 hours of the experiment. Results also showed that oxygen present initially delays but does not inhibit U(VI) reduction. Although BrY only reduces $\mathrm{U}(\mathrm{VI})$ by $30 \%$ of the rate at which it reduces $\mathrm{Fe}(\mathrm{III})$, it is always comparable but most often surpasses the performance of other metal reducing species. 


\section{CHAPTER 3}

\section{THEORETICAL BACKGROUND}

Before presenting the experimental procedure and results, it is necessary to understand uranium chemistry, electrochemistry, and possible electrosorption mechanisms. An understanding of uranium chemistry is important so that attempts can be made at understanding the uranium electrosorption process.

The form of uranium ions in solution can vary greatly depending on $\mathrm{pH}$ and has been shown to affect the performance of the removal process [4]. A summary of the various types and characteristics of precipitates and the various forms of ions in solution are presented in the following section. Additional sections describe traditional electrochemical techniques, highlight the difference between electrodeposition and electrosorption, and discuss possible mechanisms that could be responsible for the effectiveness these carbon nanofiber electrodes to remove uranium.

\subsection{Uranium Chemistry}

Uranium is often regarded as a rare element; however, it is abundant in nature when compared to elements such as cadmium, barium, and mercury. The uranium content in the earth's crust is $1 \times 10^{-3} \%$ (by weight) [36]. It does, however, occur mostly in the dispersed state. Mined deposits of naturally occurring uranium are typically ores comprised of $99.28 \% \mathrm{U}^{238}, 0.71 \% \mathrm{U}^{235}$, and $0.01 \% \mathrm{U}^{234}$. The most abundant, $\mathrm{U}^{238}$, also has the longest half-life of $4.50 \times 10^{9}$ years. The most important uranium-bearing minerals are pitchblends $\left(\mathrm{U}_{3} \mathrm{O}_{8}\right)$ and carnotite $\left(\mathrm{K}_{2}\left(\mathrm{UO}_{2}\right)_{2}\left(\mathrm{VO}_{4}\right)_{2} \cdot \mathrm{nH}_{2} \mathrm{O}\right)$ [15].

Prior to World War II, only rich uranium ores were worked because of the insignificant consumption of the element. In the postwar period, however, the working of lean ores on a large scale became necessary due to the use of uranium for military purposes and nuclear-power engineering, as well as the depletion of rich ore deposits. Because of these newfound uses of uranium, it was investigated extensively during the 1950 's, 60's, and 70's. A summary of the important information gathered during this time is summarized in the following sections. 


\subsubsection{Properties of Uranium Compounds}

Uranium is an extremely dense metal, closely resembling steel in appearance. It can be found with three different crystalline modifications including alpha, beta, and gamma structures. A summary of the physical properties of elemental uranium is presented in Table 3-1.

Table 3-1. Physical Properties of Uranium [37]

\begin{tabular}{||l|c||}
\hline \multicolumn{1}{|c||}{ Properties } & Values \\
\hline \hline Melting Point & $1132 \pm 1^{\circ} \mathrm{C}$ \\
\hline Boiling Point & $3318^{\circ} \mathrm{C}$ \\
\hline Density $\left(25^{\circ} \mathrm{C}\right)$ & $19.04 \mathrm{~g} / \mathrm{cm}^{3}$ \\
\hline Latent Heat of Fusion & $4.7 \mathrm{kcal} / \mathrm{mole}$ \\
\hline Latent Heat of Evaporation & $106.7 \mathrm{cal} / \mathrm{mole}$ \\
\hline Enthalpy $\left(25^{\circ} \mathrm{C}\right)$ & $1521.4 \mathrm{cal} / \mathrm{mole}$ \\
\hline Entropy $\left(25^{\circ} \mathrm{C}\right)$ & $11.99 \mathrm{cal} / \mathrm{deg} \cdot \cdot \mathrm{mole}$ \\
\hline Electrical Conductivity & $2.4 \cdot 10^{4}(\mathrm{ohm} \cdot \mathrm{cm})^{-1}$ \\
\hline Thermal Conductivity & $0.071 \mathrm{cal} / \mathrm{cm} \cdot \mathrm{sec} \cdot \mathrm{deg}$ \\
\hline Surface Hardness (Rockwell) & 100 \\
\hline
\end{tabular}

Three uranium oxides are known to exist for certain including the dioxide $\left(\mathrm{UO}_{2}\right)$, the trioxide $\left(\mathrm{UO}_{3}\right)$, and the mixed oxide $\left(\mathrm{U}_{3} \mathrm{O}_{8}\right)$. It has also been speculated that the existence of a fourth oxide, the monoxide (UO), also exists but is not widely observed [38]. The properties of the three common oxides are summarized in Table 3-2.

Table 3-2. Properties of Uranium Oxides [15]

\begin{tabular}{|c|c|c|c|}
\hline & Dioxide $\left(\mathrm{UO}_{2}\right)$ & Trioxide $\left(\mathrm{UO}_{3}\right)$ & Mixed Oxide $\left(\mathrm{U}_{3} \mathrm{O}_{8}\right)$ \\
\hline Appearance & Dark-brown powder & $\begin{array}{l}\text { Red to yellow powder, } \\
\text { depending on the } \\
\text { crystalline modification }\end{array}$ & Black or dark green powder \\
\hline Preparation & $\begin{array}{l}\text { Reduction of higher } \\
\text { uranium oxides with } \\
\text { hydrogen }\end{array}$ & $\begin{array}{l}\text { Reduction of higher } \\
\text { uranium oxides }\end{array}$ & Igniting $\mathrm{UO}_{2}$ or $\mathrm{UO}_{3}$ in air \\
\hline $\begin{array}{l}\text { Solubility } \\
\text { In Acids }\end{array}$ & $\begin{array}{l}\text { Not soluble in } \mathrm{HCl} \text {, Soluble } \\
\text { in } \mathrm{HNO} 3 \text { and heated, } \\
\text { concentrated } \mathrm{H} 2 \mathrm{SO} 4\end{array}$ & $\begin{array}{l}\text { Soluble in all mineral acids } \\
\text { and acetic acid }\end{array}$ & $\begin{array}{l}\text { Sparingly soluble in dilute } \\
\mathrm{HCl} \text {, readily soluble in } \\
\text { heated, concentrated } \mathrm{HCl} \text {, } \\
\text { also soluble in } \mathrm{HNO}_{3} \text { and } \\
\mathrm{H}_{2} \mathrm{SO}_{4}\end{array}$ \\
\hline
\end{tabular}

The affinity of uranium oxides for water increases from $\mathrm{UO}_{2}$ to $\mathrm{U}_{3} \mathrm{O}_{8}$ to $\mathrm{UO}_{3}$. The hydrate of uranium dioxide $\left(\mathrm{UO}_{2} \cdot \mathrm{nH}_{2} \mathrm{O}\right)$ is obtained from the reaction of ammonia or 
alkalis with a solution of a U(IV) salt, or from the hydrolysis of dilute solutions of U(IV) chloride or acetate. In air, the hydrate is easily oxidized to $\mathrm{UO}_{3} \cdot \mathrm{H}_{2} \mathrm{O}$. After drying over sulfuric acid, the hydrate has the composition $\mathrm{UO}_{2} \cdot 2 \mathrm{H}_{2} \mathrm{O}$. The freshly prepared U(IV) hydroxide is readily soluble in acids, but its solubility decreases upon standing [15].

Several hydrates of $\mathrm{UO}_{3}$ also exist including $\mathrm{UO}_{3} \cdot \mathrm{H}_{2} \mathrm{O}\left(\mathrm{H}_{2} \mathrm{UO}_{4}\right), \mathrm{UO}_{3} \cdot 2 \mathrm{H}_{2} \mathrm{O}$ $\left(\mathrm{H}_{4} \mathrm{UO}_{5}\right)$, and $2 \mathrm{UO}_{3} \cdot \mathrm{H}_{2} \mathrm{O}\left(\mathrm{H}_{2} \mathrm{U}_{2} \mathrm{O}_{7}\right)$. These hydrates are much more stable than the hydrates of the dioxide and are only slightly soluble in water [15].

\subsubsection{Uranium Ions in Solution}

Uranium can be present in solution as ions or ionic groups with four oxidation states: $3+, 4+, 5+$, and $6+$. Among them, $6+$ is the most common and natural form in solution while $3+$ and $5+$ are relatively unstable. The oxidation state of $6+$ typically occurs in the form of the uranyl ion, $\mathrm{UO}_{2}{ }^{2+}[15]$.

\subsubsection{Trivalent Uranium}

Aqueous solutions of U(III) can be prepared by dissolving its salts or by reducing solutions of $\mathrm{U}(\mathrm{IV})$ or $\mathrm{U}(\mathrm{VI})$. The cation can be easily oxidized to U(IV) even in the absence of oxygen and its presence slowly reduces water to free hydrogen. As stated previously, U(III) is unstable, causing a hindrance in the study of its complex formation and hydrolysis; however, existing data suggest that U(III) has a low complexing capacity. It should also be noted that the salts of U(III) in solution are less hydrolyzed than those of U(IV), but more than those of U(VI), as shown in Table 3-3.

Table 3-3. pHs of 0.02M Solutions of Various Uranium Ions [39]

\begin{tabular}{|l||c|c|c||}
\hline \hline Ion & $\mathrm{U}^{3+}$ & $\mathrm{U}^{4+}$ & $\mathrm{UO}_{2}{ }^{2+}$ \\
\hline pH of Solution & 2.4 & 1.3 & 2.9 \\
\hline
\end{tabular}

\subsubsection{Tetravalent Uranium}

Solutions of U(IV) can be obtained by dissolving its salts or by reducing solutions of $\mathrm{U}(\mathrm{VI})$. This reduction can be achieved through the use of various metals including $\mathrm{Pb}$, $\mathrm{Zn}, \mathrm{Bi}, \mathrm{Ag}$, and $\mathrm{Cd}$. The reduction is normally achieved in an acidic solution because this 
type of environment is more conducive to qualitative reduction. Uranium (IV) is typically present in solution as the simple ion $\mathrm{U}^{4+}$ or possibly as $\mathrm{U}\left(\mathrm{H}_{2} \mathrm{O}\right)_{\mathrm{n}}{ }^{4+}$, where $\mathrm{n}=6$ or 8 [15].

The presence of U(IV) salts results in an acidic solution caused by hydrolysis. The reaction of the hydrolysis is shown below.

$$
\mathrm{U}^{4+}+\mathrm{H}_{2} \mathrm{O}=\mathrm{UOH}^{3+}+\mathrm{H}^{+}
$$

This reaction, when extensive, can cause the formation of poly-nuclear ions of the type $\mathrm{U}\left[(\mathrm{OH})_{3} \mathrm{U}\right]_{\mathrm{n}}{ }^{4+\mathrm{n}}$ and also polymers $\left[\mathrm{U}(\mathrm{OH})_{4}\right]_{\mathrm{x}}[40]$. Reaction 3-1 is strongly temperature dependent as shown in Table 3-4 which presents hydrolysis constants $\left(\mathrm{K}_{a}\right)$ at various temperatures [41].

Table 3-4. Values of the Hydrolysis Constants of $\mathrm{U}^{4+}$ at Various Temperatures (Ionic Strength ì $=0.5 ; \mathrm{U}^{4+}+\mathrm{H}_{2} \mathrm{O} \mathrm{UOH}^{3+}+\mathrm{H}^{+}$)

\begin{tabular}{||c||c|c|c||}
\hline Temperature $\left({ }^{\circ} \mathbf{C}\right)$ & 10 & 25 & 43 \\
\hline Value of $\boldsymbol{K}_{a}$ & 0.075 & 0.21 & 0.66 \\
\hline
\end{tabular}

Uranium (III) is often formed throughout the reduction process but is easily and quickly oxidized to U(IV) by atmospheric oxygen. A mercury cathode can be used to reduce $\mathrm{U}(\mathrm{VI})$ to $\mathrm{U}(\mathrm{IV})$ electrolytically and quantitatively [42]. Reduction can also be achieved through a photochemical reaction with alcohol [43], ether [44], or lactic acid [45]. Finally, U(IV) can also be obtained by reduction of uranyl nitrate with rongalite $\left(\mathrm{CH}_{2} \mathrm{O} \cdot \mathrm{NaHSO}_{2} \cdot 2 \mathrm{H}_{2} \mathrm{O}\right)$ in nitric acid [46].

Cold, acidic solutions of U(IV) are fairly stable in darkness; however, it has been shown that its oxidation in air is significantly increased with exposure to light, particularly direct sunlight or ultraviolet light. The reaction proceeds as shown below.

$$
\begin{gathered}
\mathrm{U}^{4+}+h v \rightarrow\left(\mathrm{U}^{4+}\right)^{*} \\
\left(\mathrm{U}^{4+}\right)^{*}+\mathrm{O}_{2} \rightarrow \mathrm{UO}_{2}{ }^{2+}
\end{gathered}
$$


A quantum of light is indicated by $h v$ and an asterisk indicates an excited uranium ion [47].

\subsubsection{Pentavalent Uranium}

Dilute solutions of $\mathrm{U}(\mathrm{V})$ can be obtained through the electrolytic reduction of $\mathrm{U}(\mathrm{VI})$ at $\mathrm{pH} 2.5$ to 3.0. It has been shown that solutions of up $90 \% \mathrm{U}(\mathrm{V})$ can be obtained by reducing $\mathrm{U}(\mathrm{VI})$ on a platinized platinum electrode at very specific conditions $\left(1^{\circ} \mathrm{C}, \mathrm{pH}\right.$ $2.5-3.0, \mathrm{U}(\mathrm{VI})$ concentration of $\left.1 \cdot 10^{-3} \mathrm{M}\right)[48]$.

Uranium (V) is always present in solution in equilibrium with $\mathrm{U}(\mathrm{IV})$ and $\mathrm{U}(\mathrm{VI})$ due to the disproportionation of $\mathrm{U}(\mathrm{V})$ to $\mathrm{U}(\mathrm{IV})$ and $\mathrm{U}(\mathrm{VI})$. It exists as the $\mathrm{UO}_{2}{ }^{+}$ion and it has been hypothesized that the disproportionation occurs in perchloric acid according to the following reaction [49].

$$
\begin{aligned}
\mathrm{UO}_{2}^{+}+\mathrm{H}^{+} & =\mathrm{UOOH}^{2+} \\
\mathrm{UO}_{2}^{+}+\mathrm{UOOH}^{2+} & =\mathrm{UO}_{2}^{2+}+\mathrm{UOOH}^{+} \\
\mathrm{UOOH}^{+} & \rightarrow \mathrm{UO}^{4+}
\end{aligned}
$$

or

$$
2 \mathrm{UO}_{2}^{+}+4 \mathrm{H}_{3} \mathrm{O}^{+} \rightarrow \mathrm{UO}_{2}^{2+}+\mathrm{U}^{4+}+6 \mathrm{H}_{2} \mathrm{O}
$$

The equilibrium constant of the above-detailed process is $(1.7 \pm 0.3) \times 10^{6}$ [50]. Uranium $(\mathrm{V})$ is most easily maintained in solution with little disproportionation when the $\mathrm{pH}$ is kept between 2 and 40 .

\subsubsection{Hexavalent Uranium}

Of the four oxidation states, $\mathrm{U}(\mathrm{VI})$ is the most relevant because it is the one used in the present study. As stated previously, U(VI) is most often present as the uranyl ion $\left(\mathrm{UO}_{2}{ }^{2+}\right)$. It has been established that at $\mathrm{pHs}$ equal to or below 2.5, the uranyl ion predominates over other species; while at higher $\mathrm{pHs}$, the uranyl ions are dominated by composite hydrolyzed ions (i.e., $\left(\mathrm{UO}_{2}\right)_{2}(\mathrm{OH})_{2}{ }^{+},\left(\mathrm{UO}_{2}\right)_{3}(\mathrm{OH})_{5}{ }^{+}$, and $\left.\mathrm{UO}_{2} \mathrm{OH}^{+}\right)$. Further, it has been determined through the X-ray analysis of several crystalline compounds of $\mathrm{U}(\mathrm{VI})$, that $\mathrm{UO}_{2}{ }^{2+}$ is a linear radical in which $\mathrm{U}-\mathrm{O}$ bond is partly covalent. It has also been shown that $\mathrm{UO}_{2}{ }^{2+}$ in solution is a linear radical [39]. 
Several investigations into the dissociation of uranyl salts have been completed. One study found that uranium in concentrated nitric acid is present predominately as undissociated molecules of $\mathrm{UO}_{2}\left(\mathrm{NO}_{3}\right)_{2}$. Likewise, aqueous solutions of uranyl sulfate contain amounts of undissociated $\mathrm{UO}_{2} \mathrm{SO}_{4}$. Uranyl acetate has been found to dissociate incompletely, even more so than uranyl sulfate. Upon combining these studies, the uranyl salts can be arranged according to degree of dissociation from most to least as follows: $\mathrm{UO}_{2}\left(\mathrm{ClO}_{4}\right)_{2}>\mathrm{UO}_{2} \mathrm{Cl}_{2}>\mathrm{UO}_{2}\left(\mathrm{NO}_{3}\right)_{2}>\mathrm{UO}_{2} \mathrm{SO}_{4}>\mathrm{UO}_{2}\left(\mathrm{CH}_{3} \mathrm{COO}\right)_{2}$ [39].

Activity coefficients of the uranyl ion based on the molarity of $\mathrm{UO}_{2}(\mathrm{NO})_{3}$ in an aqueous solution are presented in Table 3-5. Additional data, which summarize the activity coefficients of the uranyl ion based on various ionic strengths of solution, are shown in Table 3-6. The values demonstrate the dependence of the activity coefficient on the concentration of the solution; the activity coefficient becomes large at high concentrations.

Table 3-5. Activity Coefficients of $\mathrm{UO}_{2}{ }^{2+}$ in Uranyl Nitrate Solution [51]

\begin{tabular}{|l||c|c|c|c|c|c|c|c|c|c|c||}
\hline $\begin{array}{l}\text { Molarity of } \\
\mathbf{U O}_{2}\left(\mathbf{N O}_{3}\right)_{\mathbf{2}}\end{array}$ & 0.1 & 0.2 & 0.3 & 0.5 & 0.7 & 1.0 & 1.5 & 2.0 & 2.5 & 3.0 & 3.5 \\
\hline $\begin{array}{l}\text { Activity Coefficient } \\
\text { of } \mathbf{U O}_{2}^{2+}, \mathbf{a}\end{array}$ & 0.573 & 0.543 & 0.540 & 0.564 & 0.617 & 0.721 & 0.959 & 1.288 & 1.670 & 2.120 & 3.470 \\
\hline
\end{tabular}

Although a significant amount of information is known about the behavior of the uranyl ion at pHs below 2.5, little is known with great certainty about its behavior at pHs above 2.5 due to its complicated nature. Because of the acidic nature of dissolved uranyl salts, hydrolysis of $\mathrm{UO}_{2}{ }^{2+}$ is indicated. Although much research has been completed in this area, the results are inconclusive; overall, the following hydrolysis products are assumed to exist: $\mathrm{U}_{2} \mathrm{O}_{5}{ }^{2+}, \mathrm{U}_{3} \mathrm{O}_{8}{ }^{2+},\left[\mathrm{UO}_{2}(\mathrm{OH})\right]^{+},\left[\mathrm{U}_{3} \mathrm{O}_{8}(\mathrm{OH})\right]^{+}, \mathrm{U}_{3} \mathrm{O}_{8}(\mathrm{OH})_{2},\left[\mathrm{U}_{3} \mathrm{O}_{8}(\mathrm{OH})_{3}\right]^{-}$, and others. 
Table 3-6. Activity Coefficients of the Uranyl Ion as a Function of the Ionic Strength of the Solution [52]

\begin{tabular}{||c|c||}
\hline \hline $\begin{array}{c}\text { Ionic Strength of } \\
\text { Solution, } \boldsymbol{\mu}\end{array}$ & $\begin{array}{c}\text { Activity coefficient } \\
\text { of } \mathbf{U O}_{2}{ }^{2+}, \mathbf{a}\end{array}$ \\
\hline \hline 0.002 & 0.868 \\
\hline 0.003 & 0.858 \\
\hline 0.004 & 0.830 \\
\hline 0.007 & 0.794 \\
\hline 0.012 & 0.699 \\
\hline 0.022 & 0.608 \\
\hline 0.042 & 0.567 \\
\hline 0.080 & 0.488 \\
\hline 0.109 & 0.473 \\
\hline 0.139 & 0.451 \\
\hline 0.201 & 0.425 \\
\hline 0.261 & 0.422 \\
\hline 0.335 & 0.462 \\
\hline
\end{tabular}

\begin{tabular}{|c|c|}
\hline $\begin{array}{l}\text { Ionic Strength of } \\
\text { Solution, } \mu\end{array}$ & $\begin{array}{c}\text { Activity coefficient } \\
\text { of } \mathrm{UO}_{2}{ }^{2+}, \tilde{\mathbf{a}}\end{array}$ \\
\hline 0.500 & 0.430 \\
\hline 0.600 & 0.440 \\
\hline 0.900 & 0.500 \\
\hline 1.200 & 0.600 \\
\hline 1.500 & 0.740 \\
\hline 1.800 & 0.920 \\
\hline 2.100 & 1.160 \\
\hline 2.400 & 1.490 \\
\hline 2.700 & 1.950 \\
\hline 3.000 & 2.570 \\
\hline 3.600 & 4.610 \\
\hline 4.200 & 8.350 \\
\hline
\end{tabular}

It has been established that polynuclear, doubly charged, uranium-oxygen ions have a complicated structure [53]. The hydrolysis constants of the uranyl ion are shown in Table 3-7.

Table 3-7. Hydrolysis Constants of $\mathrm{UO}_{2}{ }^{2+}$

\begin{tabular}{|c|c|c|}
\hline Hydrolysis Reaction & $\begin{array}{l}\text { Hydrolysis } \\
\text { Constants }\end{array}$ & "Reference \\
\hline $\mathrm{UO}_{2}^{2+}+2 \mathrm{H}_{2} \mathrm{O}=\mathrm{UO}_{2}(\mathrm{OH})^{+}+\mathrm{H}_{3} \mathrm{O}^{+}$ & $\begin{array}{c}(2.0 \pm 0.4) \times 10^{-5} \\
6.4 \times 10^{-5} \\
6.0 \times 10^{-5}\end{array}$ & $\begin{array}{l}{[54]} \\
{[55]} \\
{[39]}\end{array}$ \\
\hline $\mathrm{UO}_{2}(\mathrm{OH})^{+}+2 \mathrm{H}_{2} \mathrm{O}=\mathrm{UO}_{2}(\mathrm{OH})_{2}+\mathrm{H}_{3} \mathrm{O}^{+}$ & $4.6 \times 10^{-4}$ & [39] \\
\hline $2 \mathrm{UO}_{2}^{2+}+3 \mathrm{H}_{2} \mathrm{O}=\mathrm{UO}_{3} \cdot \mathrm{UO}_{2}^{2+}+2 \mathrm{H}_{3} \mathrm{O}^{+}$ & $\begin{array}{c}1.35 \times 10^{-6} \\
\sim 2 \times 10^{-6} \\
1.14 \times 10^{-6} \\
10^{-6.05} \pm 0.1 \\
4.1 \times 10^{-3}\end{array}$ & $\begin{array}{l}{[39]} \\
{[39]} \\
{[56]} \\
{[40]} \\
{[54]}\end{array}$ \\
\hline $\mathrm{UO}_{2}{ }^{2+}+\mathrm{U}_{2} \mathrm{O}_{5}{ }^{2+}+3 \mathrm{H}_{2} \mathrm{O}=\mathrm{U}_{3} \mathrm{O}_{8}{ }^{2+}+2 \mathrm{H}_{3} \mathrm{O}^{+}$ & $5 \times 10^{-9}$ & [56] \\
\hline $\mathrm{U}_{3} \mathrm{O}_{8}{ }^{2+}+2 \mathrm{H}_{2} \mathrm{O}=\mathrm{U}_{3} \mathrm{O}_{8}(\mathrm{OH})^{+}+\mathrm{H}_{3} \mathrm{O}^{+}$ & $2.8 \times 10^{-4}$ & [56] \\
\hline $\mathrm{U}_{3} \mathrm{O}_{8}(\mathrm{OH})^{+}+2 \mathrm{H}_{2} \mathrm{O}=\mathrm{U}_{3} \mathrm{O}_{8}(\mathrm{OH})_{2}+\mathrm{H}_{3} \mathrm{O}^{+}$ & $3 \times 10^{-7}$ & [56] \\
\hline $\mathrm{U}_{3} \mathrm{O}_{8}(\mathrm{OH})_{2}+2 \mathrm{H}_{2} \mathrm{O}=\mathrm{U}_{3} \mathrm{O}_{8}(\mathrm{OH})_{3}^{-}+\mathrm{H}_{3} \mathrm{O}^{+}$ & $4 \times 10^{-8}$ & [56] \\
\hline $\mathrm{U}_{3} \mathrm{O}_{8}(\mathrm{OH})_{3}{ }^{-}+2 \mathrm{H}_{2} \mathrm{O}=\mathrm{U}_{3} \mathrm{O}_{8}(\mathrm{OH})_{4}{ }^{2-}+\mathrm{H}_{3} \mathrm{O}^{+}$ & $1 \times 10^{-11}$ & [56] \\
\hline $\mathrm{U}_{3} \mathrm{O}_{8}(\mathrm{OH})_{4}{ }^{2-}+2 \mathrm{H}_{2} \mathrm{O}=\mathrm{U}_{3} \mathrm{O}_{8}(\mathrm{OH})_{5}{ }^{3-}+\mathrm{H}_{3} \mathrm{O}^{+}$ & $4 \times 10^{-12}$ & [56] \\
\hline
\end{tabular}

A study was conducted on the hydrolysis of the uranyl ion by means of a potentiometric titration of uranyl solutions with alkali [52]. It was determined that upon the addition of alkali to a $\mathrm{OH}^{-}: \mathrm{UO}_{2}^{2+}$ ratio of 0 to 1 , uranyl ions are mainly converted to 
$\left[\mathrm{UO}_{2}(\mathrm{OH})\right]^{+}$. Upon further addition of alkali, increasing the ratio to above 1 , a condensation process sets in and causes an increase in the number of polymeric, singlycharged ions $\left(\mathrm{UO}_{2}\left(\mathrm{UO}_{3}\right)_{\mathrm{n}} \mathrm{OH}^{+}\right)$. Still further addition of alkali, increasing the ratio to between 1.4 and 1.6, results in the formation of a metastable colloidal solution containing unstable polymers of $\left[\mathrm{UO}_{2}\left(\mathrm{UO}_{3}\right)_{\mathrm{n}} \mathrm{OH}\right]^{+}$that are unstable and therefore converted to colloidal uranyl hydroxide. This colloid decomposes and $\mathrm{UO}_{3} \cdot \mathrm{nH} 2 \mathrm{O}$ is precipitated. Once the ratio reaches values between 1.4-1.6 and 1.9-2.0, uranyl hydroxide is precipitated. Finally, the further addition of alkali causes the hydroxide to be converted to uranates and polyuranates. Table 3-8 shows precipitation $\mathrm{pH}$ as a function of $\mathrm{UO}_{2}{ }^{2+}$ concentration [52].

Table 3-8. $\mathrm{pH}$ at Precipitation Initiation as a Function of $\mathrm{UO}_{2}{ }^{2+}$ Concentration in Solution

\begin{tabular}{||l||c|c|c|c|c|c||}
\hline Conc. Of Uranyl Perchlorate, $\boldsymbol{M}$ & 0.1 & 0.01 & 0.001 & 0.0001 & 0.00003 & 0.00001 \\
\hline pH at Initiation of Precipitation & 4.47 & 5.27 & 5.90 & 6.62 & 6.80 & 7.22 \\
\hline
\end{tabular}

Solubility products of uranyl hydroxide $\left(20^{\circ} \mathrm{C}\right)$ are

$$
\begin{aligned}
& \mathrm{SP}_{1}=\frac{\left[\mathrm{UO}_{2} \mathrm{OH}^{+}\right]\left[\mathrm{OH}^{-}\right]}{\left[\mathrm{UO}_{2}(\mathrm{OH})_{2}\right]}=1.3 \cdot 10^{-12} \\
& \mathrm{SP}_{2}=\frac{\left[\mathrm{UO}_{2}^{2+}\right]\left[\mathrm{OH}^{-}\right]^{2}}{\left[\mathrm{UO}_{2}(\mathrm{OH})_{2}\right]}=(6 \pm 2) \cdot 10^{-18} \quad \text { (Brusilovski, 1958). }
\end{aligned}
$$

Recently, hydrolysis of the uranyl ion and the dependence of the hydrolysis on both temperature and ionic strength of solution have been studied [57]. It is still maintained that the phenomenon is explained by the formation of the monomer $\left[\mathrm{UO}_{2} \mathrm{OH}\right]^{+}$according to the reaction

$$
\mathrm{UO}_{2}^{2+}+\mathrm{H}_{2} \mathrm{O}=\left(\mathrm{UO}_{2} \mathrm{OH}\right)^{+}+\mathrm{H}^{+}
$$

and the dimer $\left[\mathrm{UO}_{2} \cdot \mathrm{UO}_{3}\right]^{2+}$ according to the reaction

$$
2 \mathrm{UO}_{2}^{2+}+\mathrm{H}_{2} \mathrm{O}=\left(\mathrm{UO}_{2} \cdot \mathrm{UO}_{3}\right)^{2+}+2 \mathrm{H}^{+}
$$


The hydrolysis constants are also shown below

$$
\begin{gathered}
\mathrm{K}_{1}=\frac{\left\lfloor\left(\mathrm{UO}_{2} \mathrm{OH}\right)^{+}\right]\left[\mathrm{H}^{+}\right]}{\left[\mathrm{UO}_{2}^{2+}\right]} \\
\mathrm{K}_{2}=\frac{\left[\left(\mathrm{UO}_{2} \cdot \mathrm{UO}_{3}\right)^{2+}\right]\left[\mathrm{H}^{+}\right]^{2}}{\left[\mathrm{UO}_{2}^{2+}\right]^{2}}
\end{gathered}
$$

and the temperature and ionic strength dependence are illustrated in Table 3-9.

Table 3-9. Temperature and Ionic Strength Dependence of Hydrolysis Constants of $\mathrm{UO}_{2}{ }^{2+}$

\begin{tabular}{|c|c|c||}
\hline \hline Conditions (ionic strength and temp.) & $\mathbf{K}_{\mathbf{1}}$ & $\mathbf{K}_{\mathbf{2}}$ \\
\hline$\mu=0.347 ; 25^{\circ} \mathrm{C}$ & $4 \cdot 10^{6}$ & $1.5 \cdot 10^{6}$ \\
\hline$\mu=0.0347 ; 25^{\circ} \mathrm{C}$ & $1.5 \cdot 10^{6}$ & $0.7 \cdot 10^{6}$ \\
\hline$\mu=0.0347 ; 40^{\circ} \mathrm{C}$ & $8 \cdot 10^{6}$ & $1.2 \cdot 10^{6}$ \\
\hline
\end{tabular}

\subsubsection{Uranium Species as a Function of $\mathbf{p H}$}

As illustrated in the previous section, the species of uranium present in an aqueous solution is a strong function of the $\mathrm{pH}$. Computer software is now available (MINEQL+, etc.) which can predict the species distribution across a range of $\mathrm{pH}$ for any solution of a given ionic strength and summarize the results in the form of a species diagram. These diagrams were previously generated during studies conducted at WVU [4]. The diagrams show the species distribution for a solution of $0.1 \mathrm{M} \mathrm{KNO3}$ containing 100ppm uranium, the same solution used as the synthetic uranium waste feed for the experiments presented herein. These diagrams are presented for the two major oxidation states, $4^{+}$and $6^{+}$, as Figures 3-1 and 3-2, respectively.

Figure 3-1 illustrates the low solubility of $\mathrm{UO}_{2}$ even in very acidic solutions. It can be seen that the concentrations of $\mathrm{U}^{4+}$ and $\mathrm{UOH}^{3+}$, even at very low $\mathrm{pH}$, are less than $10^{-5}$. It is worth reiterating that the figure represents the equilibrium state of the species and much higher concentrations may exist at various points in time. It is also worth noting that because this diagram was constructed for a $0.1 \mathrm{M}$ solution of $\mathrm{KNO}_{3}$, the 
effects of a change in oxidation due to stronger acids (concentrated nitric acid) is neglected. These points are however discussed later in the section that addresses the relationship between potential and $\mathrm{pH}$.

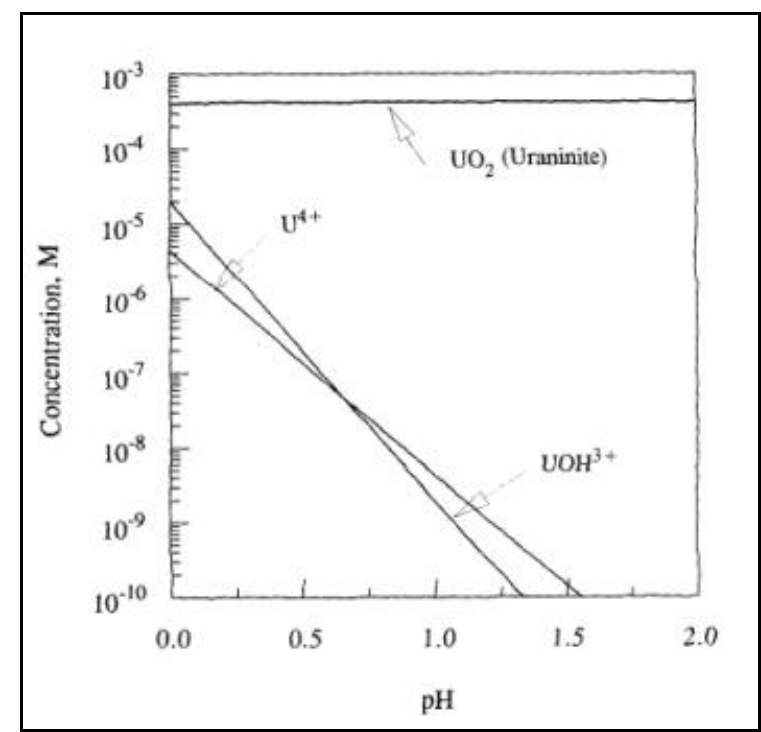

Figure 3 - 1. Equilibrium Concentration of Uranium (IV) [4]

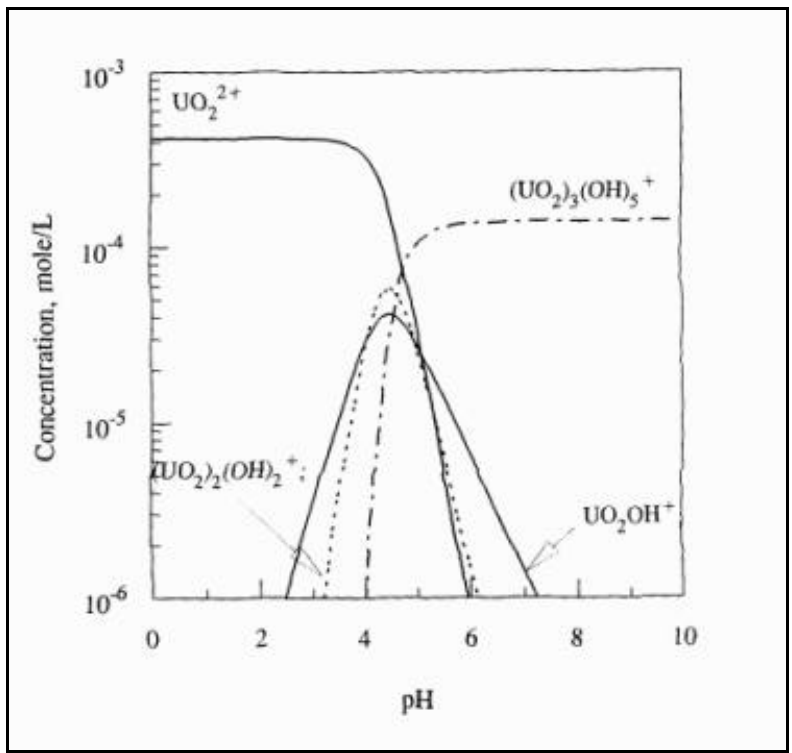

Figure 3 - 2. Equilibrium Concentration of Uranium (VI) [4] 
Figure 3-2 illustrates that the chemistry of U(VI) is more complicated than that of U(IV). At pHs between 4 and 4.5, nearly all species are present in equilibrium with each other. At lower $\mathrm{pH}$, the dominant species is $\mathrm{UO}_{2}{ }^{2+}$ while at higher $\mathrm{pH}\left(\mathrm{UO}_{2}\right)_{3}(\mathrm{OH})_{5}{ }^{+}$is prevalent. Also, although not noted in this figure, several uranium hydrates are formed at pHs above 6 including $\mathrm{UO}_{3} \cdot \mathrm{H}_{2} \mathrm{O}$ which precipitates from solution. These issues are also addressed in the following section.

\subsubsection{Relationship Between $\mathrm{pH}$ and Electrochemical Potential}

A significant amount of information has been collected and compiled regarding the relationship between $\mathrm{pH}$ and potential for several species of uranium [58]. These data are presented in Table 3-10 where equations for the electrochemical potential as a function of $\mathrm{pH}$ are displayed. The data were established for solutions at $25^{\circ} \mathrm{C}$. It should be noted that the data presented in the table are not exhaustive of all uranium species, only those that are thought to be possibly present in the system used to conduct the experiments presented herein.

This data can also be interpreted graphically. Figure 3-3a shows the equilibrium diagram for the uranium-water system considering the solid substances $\mathrm{U}, \mathrm{UO}, \mathrm{U}_{2} \mathrm{O}_{3}$, $\mathrm{UO}_{2}, \mathrm{U}_{3} \mathrm{O}_{8}$, and anhydrous $\mathrm{UO}_{3}$, and shows the domains of the stability of the metal and the "green oxide" $\mathrm{U}_{3} \mathrm{O}_{8}$, the principal constituent of pitchblend, while Figure 3-3b considers the solid substances $\mathrm{UH}_{3}, \mathrm{U}, \mathrm{UO}, \mathrm{U}_{2} \mathrm{O}_{3}, \mathrm{UO}_{2}, \mathrm{U}_{3} \mathrm{O}_{8}$, and $\mathrm{UO}_{3} \cdot 2 \mathrm{H}_{2} \mathrm{O}$. It should be noted that these figures are only valid in the absence of substances with which these metals can form insoluble salts and soluble complexes. 
Table 3-10. Potentials for Oxidation/Reduction Reactions of Uranium Species [58]

\begin{tabular}{|c|c|}
\hline Reaction & Potential, V \\
\hline \multicolumn{2}{|c|}{ Two Dissolved Substances } \\
\hline $\mathrm{U}^{3+}=\mathrm{U}^{4+}+\mathrm{e}^{-}$ & $E_{0}=-0.607+0.0591 \log \left(\mathrm{U}^{4+} / \mathrm{U}^{3+}\right)$ \\
\hline $\mathrm{U}^{3+}+\mathrm{H}_{2} \mathrm{O}=\mathrm{UOH}^{3+}+\mathrm{H}^{+}+\mathrm{e}^{-}$ & $\mathrm{E}_{0}=-0.538-0.0591 \mathrm{pH}+0.0591 \log \left(\mathrm{UOH}^{4+} / \mathrm{U}^{3+}\right)$ \\
\hline $\mathrm{U}^{3+}+2 \mathrm{H}_{2} \mathrm{O}=\mathrm{UO}_{2}^{+}+4 \mathrm{H}^{+}+\mathrm{e}^{-}$ & $\mathrm{E}_{0}=0.612-0.2364 \mathrm{pH}+0.0591 \log \left(\mathrm{UO}_{2} / \mathrm{UOH}^{3+}\right)$ \\
\hline $\mathrm{UOH}^{3+}+\mathrm{H}_{2} \mathrm{O}=\mathrm{UO}^{+}+3 \mathrm{H}^{+}+\mathrm{e}^{-}$ & $\mathrm{E}_{0}=0.546-0.1773 \mathrm{pH}+0.0591 \log \left(\mathrm{UO}_{2}^{+} / \mathrm{U}^{3+}\right)$ \\
\hline $\mathrm{U}^{3+}+2 \mathrm{H}_{2} \mathrm{O}=\mathrm{UO}_{2}{ }^{2+}+4 \mathrm{H}^{+}+2 \mathrm{e}^{-}$ & $\mathrm{E}_{0}=0.333-0.1182 \mathrm{pH}+0.0591 \log \left(\mathrm{UO}_{2}{ }^{2+} / \mathrm{U}^{4+}\right)$ \\
\hline $\mathrm{UOH}^{3+}+\mathrm{H}_{2} \mathrm{O}=\mathrm{UO}_{2}{ }^{2+}+3 \mathrm{H}^{+}+2 \mathrm{e}^{-}$ & $\mathrm{E}_{0}=0.299-0.0886 \mathrm{pH}+0.0591 \log \left(\mathrm{UO}_{2}^{2+} / \mathrm{UOH}^{3+}\right)$ \\
\hline $\mathrm{UO}_{2}^{+}+\mathrm{UO}_{2}{ }^{2+}=\mathrm{e}^{-}$ & $\mathrm{E}_{0}=0.052+0.0591 \log \left(\mathrm{UO}_{2}{ }^{2+} / \mathrm{UO}_{2}^{+}\right)$ \\
\hline \multicolumn{2}{|c|}{ Limits of the Domains of Predominance } \\
\hline$\overline{\mathrm{U}^{3+} / \mathrm{U}^{4+}}$ & $\mathrm{E}_{0}=-0.607$ \\
\hline $\mathrm{U}^{3+} / \mathrm{UOH}^{3+}$ & $\mathrm{E}_{0}=-0.538-0.0591 \mathrm{pH}$ \\
\hline $\mathrm{U}^{4+} / \mathrm{UO}_{2}^{+}$ & $\mathrm{E}_{0}=0.612-0.2364 \mathrm{pH}$ \\
\hline $\mathrm{UOH}^{3+} / \mathrm{UO}_{2}^{+}$ & $\mathrm{E}_{0}=0.546-0.1773 \mathrm{pH}$ \\
\hline $\mathrm{U}^{4+} / \mathrm{UO}_{2}{ }^{2+}$ & $\mathrm{E}_{0}=0.333-0.1182 \mathrm{pH}$ \\
\hline $\mathrm{UOH}^{3+} / \mathrm{UO}_{2}^{2+}$ & $\mathrm{E}_{0}=0.299-0.0886 \mathrm{pH}$ \\
\hline $\mathrm{UO}_{2}^{+} / \mathrm{UO}_{2}^{2+}$ & $\mathrm{E}_{0}=0.052$ \\
\hline \multicolumn{2}{|c|}{ One Dissolved Substance and One Solid Substance } \\
\hline $\mathrm{U}^{4+}+2 \mathrm{H}_{2} \mathrm{O}=\mathrm{UO}_{2}+4 \mathrm{H}^{+}$ & NA \\
\hline $\mathrm{UOH}^{3+}+\mathrm{H}_{2} \mathrm{O}=\mathrm{UO}_{2}+3 \mathrm{H}^{+}$ & NA \\
\hline $\mathrm{UO}_{2}{ }^{2+}+\mathrm{H}_{2} \mathrm{O}=\mathrm{UO}_{3}+2 \mathrm{H}^{+}$ & NA \\
\hline $\mathrm{U}^{3+}+2 \mathrm{H}_{2} \mathrm{O}=\mathrm{UO}_{2}+4 \mathrm{H}^{+}+\mathrm{e}^{-}$ & $\begin{array}{l}\text { a.) } \mathrm{E}_{0}=-0.382-0.2364 \mathrm{pH}-0.0591 \log \left(\mathrm{U}^{3+}\right) \\
\text { b.) } \mathrm{E}_{0}=-0.019-0.2364 \mathrm{pH}-0.0591 \log \left(\mathrm{U}^{3+}\right)\end{array}$ \\
\hline $\mathrm{UO}_{2}=\mathrm{UO}_{2}^{2+}+2 \mathrm{e}^{-}$ & $\begin{array}{l}\text { a.) } \mathrm{E}_{0}=0.221+0.0295 \log \left(\mathrm{UO}_{2}^{2+}\right) \\
\text { b.) } \mathrm{E}_{0}=0.040+0.0295 \log \left(\mathrm{UO}_{2}^{2+}\right)\end{array}$ \\
\hline $\mathrm{U}_{3} \mathrm{O}_{8}+4 \mathrm{H}^{+}=3 \mathrm{UO}_{2}^{2+} 2 \mathrm{H}_{2} \mathrm{O}+2 \mathrm{e}^{-}$ & $\mathrm{E}_{0}=-0.403+0.1182 \mathrm{pH}+0.0886 \log \left(\mathrm{UO}_{2}{ }^{2+}\right)$ \\
\hline
\end{tabular}

a.) Uranous oxide, b.) Uranous hydroxide 

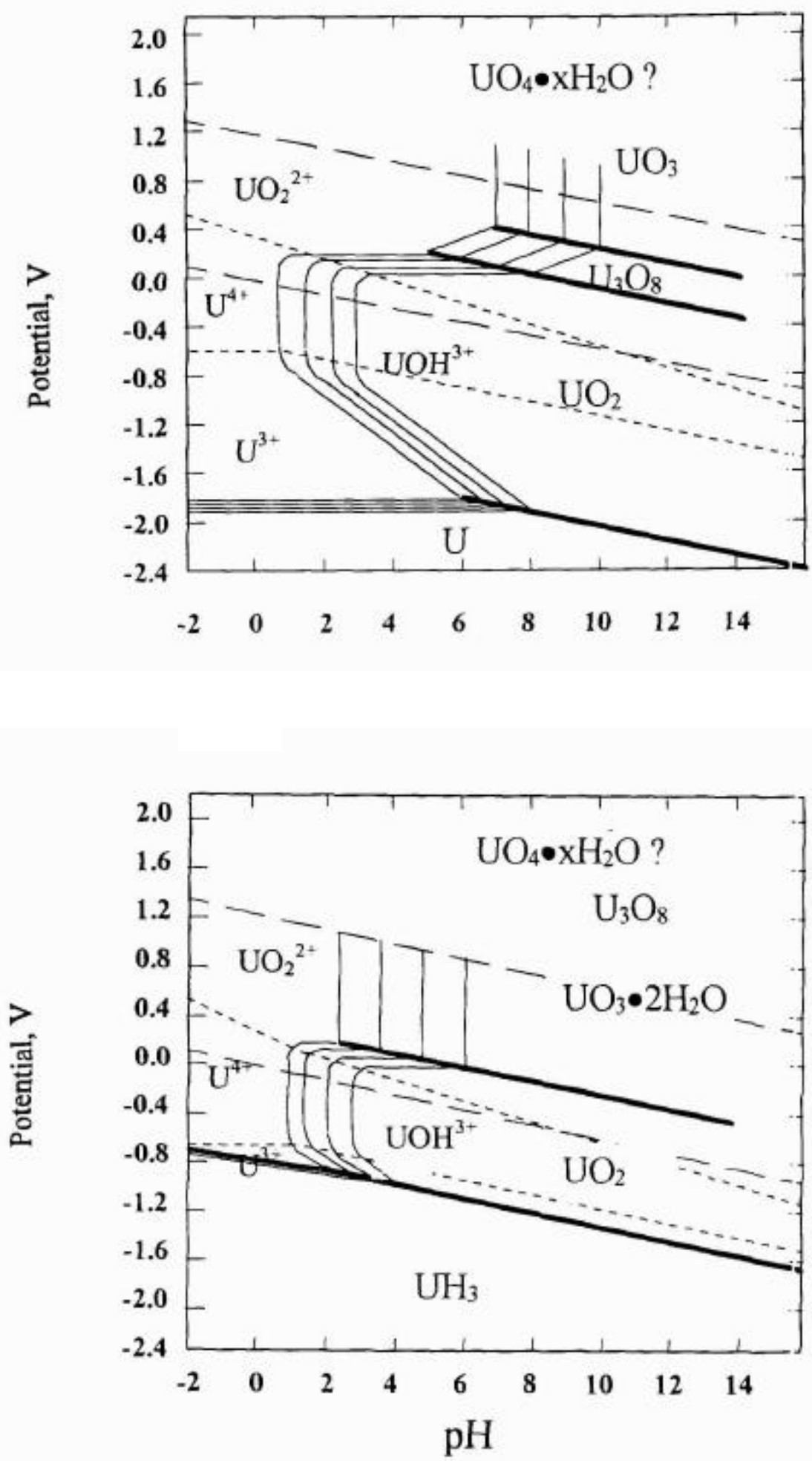

Figure 3-3 (a \& b). pH/Potential Relationship for Uranium Species [58] 


\subsection{Electrochemistry}

As stated previously, this study involves electrosorption, not electrodeposition; however, an understanding of classical electrochemistry provides a basis for speculation on the possible mechanism that is responsible for the success of this uranium removal technique. Two possible mechanisms have been proposed in previous studies and will be discussed in more detail in the following section.

An electrochemical cell consists of two electrodes, an anode and a cathode. Each electrode is submersed in a suitable electrolyte solution. An electrochemical cell can be used to measure the current being generated in the cell by a reaction that is taking place or an external source of energy can cause a reaction to take place in the cell. Regardless of the situation, the two electrodes must be connected to one another externally and submersed in electrolyte solutions that are also in contact. This allows the flow of electrons to occur by two separate techniques; one outside the cell via electrical conductivity through wires and the other inside the cell through the migration of electrons through the solution [59].

As stated previously, an electrolytic cell can be connected to a voltmeter that can measure the amount of energy generated by a chemical reaction; or, as in the case with the present study, the cell can be connected to a potentiostat that induces a potential across the electrodes and initiates a chemical reaction. Regardless of the purpose or use of the cell, an electric current will flow. This can happen by three distinct processes including the movement of electrons through the external connection (i.e., a wire, voltmeter, or potentiostat), migration of cations and anions within the electrolyte solution, and an oxidation or reduction reaction that takes place at the surface of one of the two electrodes. The electrode where the oxidation reaction (electrons released) occurs is known as the anode while the reduction reaction (electrons consumed) occurs at the cathode [59].

\subsection{Possible Electrosorption Mechanisms}

Electrochemical reactions involve the reduction of a metal ion to its elemental state on the surface of one of the two electrodes; however, as stated previously this is not possible with uranium since its reduction potential is more negative than that of water. Therefore, this process makes use of electrosorption, a technique that is not widely 
understood due to its case sensitive nature as a result of the interactive forces present at the surface of the electrodes. It is however known that electrosorption or electroadsorption as it is sometimes called is the result of an electrically enhanced adsorption process. On this basis, two possible mechanisms have been proposed and are summarized below [4].

The first of the two proposed mechanisms entertains the possibility of electrosorption as the result of the formation of double-layer charging of the carbon electrode. It is known that an electrical double layer exists at the interface between a porous carbon electrode and an electrolyte solution. The layer has an abundance of cations or anions on the solution side. These ions are adsorbed onto the electrode surface or remain in the diffuse double layer; regardless, no Faradaic (i.e., no oxidation or reduction) reactions occur during the adsorption process. Simple calculations can predict the adsorptive capacity of a given electrode material based on surface area, applied potential, and double-layer capacitance. Based on these calculations, the amount of uranium expected to be adsorbed was negligible compared to that actually observed, indicating another reaction is occurring either in place of or in addition to the double layer formation.

The second proposed mechanism was one that mimics an ion-exchange type sorption process in which surface functional groups play an important role. This explanation proposes that the induced negative potential causes a Faradaic reaction, producing hydrogen and hydroxyl ions, resulting in the dissociation of acid groups on the carbon surface. The dissociated acid groups then react with the uranyl ions, causing them to be bound to the carbon surface. This technique therefore depends on the presence of surface functional groups on the carbon nanofiber electrode, supporting the highly effective oxidized ASI fibers; however, this technique also has a limited capacity and therefore does not explain removal efficiencies. Therefore, a separate or additional phenomenon must be identified to explain the success of this process. 


\section{CHAPTER 4}

\section{EXPERIMENTAL APPARATUS AND METHODS}

The following section describes in detail the apparatus and techniques that were involved in performing the abovementioned studies.

\subsection{Carbon Materials}

As stated previously, ASI (Cedarville, OH) supplied WVU with a series of carbon nanofibers for testing. Eight fibers were initially prepared with the addition of two fibers at a later time. The fibers were produced by a catalytic vapor deposition process that allows for control of the fiber dimensions such as length and diameter. Lengths are available from $1 \mathrm{~mm}$ to tens of $\mathrm{cm}$ and diameters can vary from under 2 to over $100 \mu \mathrm{m}$. The fibers have an incredibly low density, ranging from $0.0009 \mathrm{mg} / \mathrm{cm}^{3}$ with no subsequent treatment, to $0.067 \mathrm{~g} / \mathrm{cm}^{3}$ after being pelletized with a water slurry. The fibers can also undergo other subsequent treatments that alter their surface properties including oxidation, heat treatment, and heat treatment with oxidation. Oxidation of the fibers is accomplished by placing them into a 5-in reaction tube and passing through a stream of hot air $\left(400^{\circ} \mathrm{C}\right.$ or $\left.500^{\circ} \mathrm{C}\right)$ at $1 \mathrm{~L} / \mathrm{min}$. for 90 minutes.

The method of growth and the types of post-treatments are identified by the names of the fibers. The prefix "PR-19" refers to natural gas derived nanofibers while "PR-1" refers to a fiber grown using pure methane and results in smaller diameter fibers. "PR-21" fibers are made with natural gas that is dosed with additional $\mathrm{CO}_{2}$. The fiber name suffixes indicate the post-treatment techniques. "Ox400" indicates nanofibers oxidized in air at $400{ }^{\circ} \mathrm{C}$ and "ox500" fibers oxidized in air at $500{ }^{\circ} \mathrm{C}$. "PS" nanofibers are pyrolytically stripped in $\mathrm{CO}_{2}$, "AG" nanofibers are provided as-grown with no surface treatment, and "HT" fibers are heat treated at $3,100{ }^{\circ} \mathrm{C}$ to achieve full graphitization. The specific properties of the initial eight fibers tested are presented in Table 4-1. 
Table 4 - 1. Inherent Fiber Properties

\begin{tabular}{||c|c|c|c|c|c|c||}
\hline \hline & $\begin{array}{c}\text { Surface } \\
\text { Oxygen } \\
(\text { Atomic \%) }\end{array}$ & $\begin{array}{c}\text { Surface Area } \\
\left(\mathbf{m}^{2} / \mathbf{g}\right)\end{array}$ & $\begin{array}{c}\text { Surface } \\
\text { Energy } \\
\left(\mathbf{m J} / \mathbf{m}^{2} / \mathbf{g}\right)\end{array}$ & $\begin{array}{c}\text { Diameter } \\
(\mathbf{n m})\end{array}$ & $\begin{array}{c}\text { Graph. } \\
\text { Index } \\
(\%)\end{array}$ & $\begin{array}{c}\text { Surface PAH } \\
\text { Content } \\
(\mathbf{m g} / \mathbf{g})\end{array}$ \\
\hline \hline PR-1-0x400 & 4.6 & 29.0 & 350.0 & $(125.0)$ & $(30.0)$ & 0.0 \\
\hline PR-1-ox500 & -- & -- & -- & $(125.0)$ & $(30.0)$ & 0.0 \\
\hline PR-1-AG & 1.1 & 25.0 & 48.0 & 125.0 & 30.0 & $<1.0$ \\
\hline PR-19-AG & 0.6 & 15.0 & 27.0 & 200.0 & 55.0 & $<1.0$ \\
\hline PR-21-PS & 1.9 & $25.0-35.0$ & 136.0 & $(200.0)$ & $(55.0)$ & 0.0 \\
\hline PR-19-HT & -- & 21.0 & 275.0 & $(200.0)$ & 72.0 & 0.0 \\
\hline PR-19-0x400 & -- & -- & -- & $(200.0)$ & $(55.0)$ & 0.0 \\
\hline CO-950 & -- & 190.0 & 470.0 & $(200.0)$ & $(55.0)$ & 0.0 \\
\hline PR-23-HT & -- & -- & -- & -- & -- & -- \\
\hline PR-24 & -- & -- & -- & -- & -- & -- \\
\hline \hline
\end{tabular}

Values in parentheses estimated based on AG fiber values. Data provided by ASI, missing data not available.

\subsection{Reagents}

Various solutions of uranium were prepared by diluting a stock solution of $\mathrm{UO}_{2}\left(\mathrm{NO}_{3}\right)_{2}(10,000$ ppm, Plasma Standard, SPEX Industries, Inc., Edison, NJ) with a 0.1-M solution of potassium nitrate and deionized water. The deionized water was purified using a NANOpure ${ }^{\mathrm{TM}}$ ultra-pure water purification system (BarnsteadThermolyne, Dubuque, IA). All other chemicals were certified ACS grade. The $\mathrm{pH}$ of all solutions was adjusted to 3.5 (Accumet pH meter, model AR20, Fisher Scientific), using both potassium hydroxide $(\mathrm{KOH})$ and nitric acid $\left(\mathrm{HNO}_{3}\right)$. The $\mathrm{pH}$ was maintained at 3.5 due to the results of a previous study showing the dependence of performance on $\mathrm{pH}$ [4]. This relationship is discussed in detail in Chapter 5.

\subsection{Electrolytic Cell and Fiber Loading}

The cell was a small, cylindrical, lab scale unit with an inside diameter of $1 \mathrm{~cm}$ [60]. The volume of the inner cylinder was adjustable and therefore the amount of carbon placed into the cell could be varied (usually $0.2 \mathrm{~g}$ ). The cell was equipped with three electrodes: working, auxiliary, and reference. The oxidation and reduction 
reactions occur at the working and auxiliary electrodes while the reference electrode establishes a basis to which other potentials are referenced. The reference electrode used here was a silver/silver chloride $(\mathrm{Ag} / \mathrm{AgCl})$ electrode (Bioanalytical Systems Inc., Part No. MF-2021, West Lafayette, IN). The auxiliary electrode was constructed of platinum wire bent into a coil. The carbon fibers were placed into the cell between a platinum mesh connected to a platinum wire that served to provide proper electrical contact to the fibers. A layer of filter paper was added above the fibers to keep them from being eluted from the cell. A schematic of the cell illustrating all components can be seen in Figure 41.

To minimize the voltage drop across the cell, the height of the nanofiber bed was kept small (approximately $2 \mathrm{~cm}$ although this varies with each type of fiber) and the fibers were kept under a mild compressive force. Also, the distance between the three electrodes was kept to an absolute minimum.

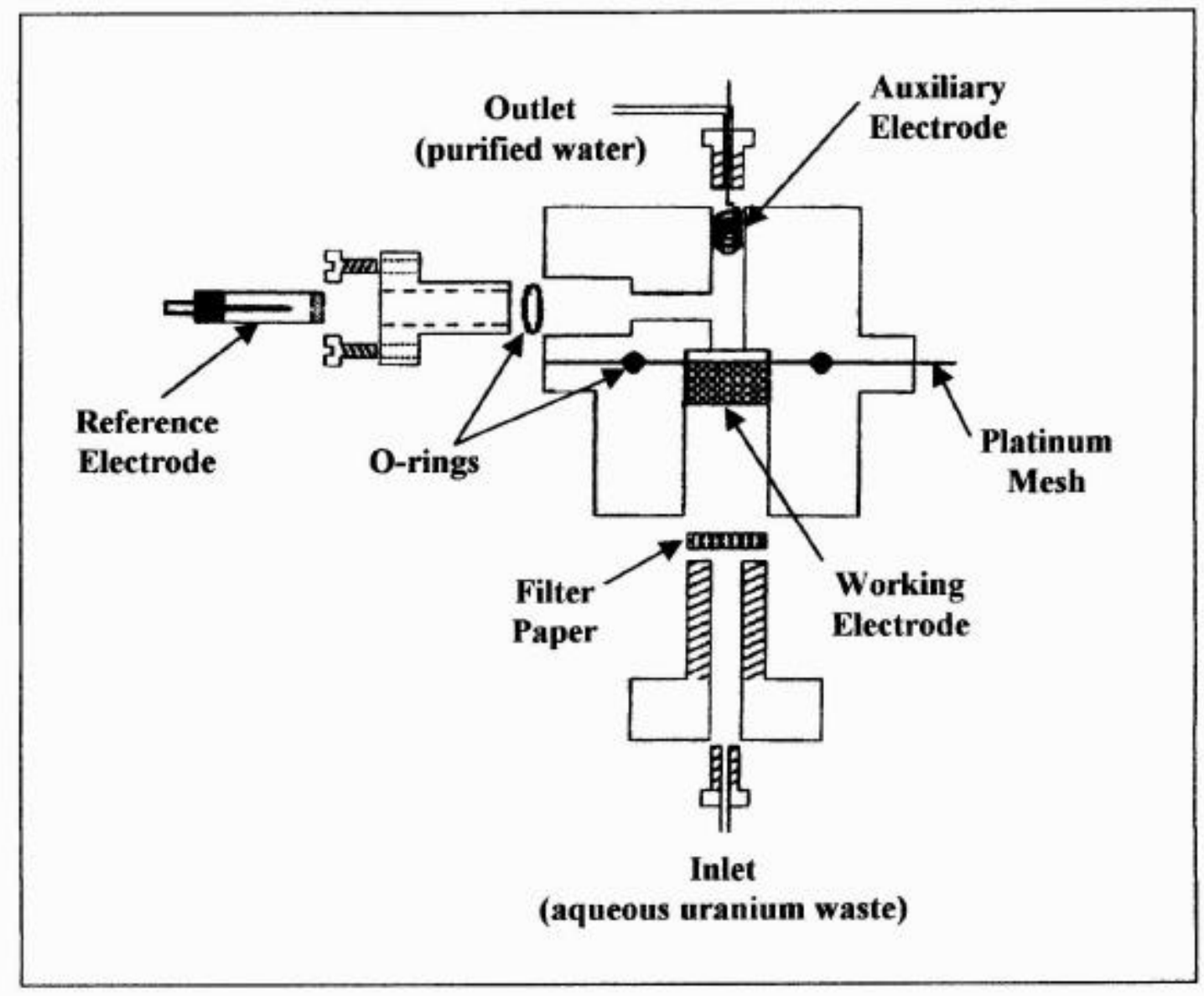

Figure 4-1. Schematic of Electrolytic Cell 
After being loaded with the carbon nanofiber material, the cell was connected to a potentiostat (Model PWR-3, Bioanalytical Systems, Inc., West Lafayette, IN) that applied a constant voltage to the carbon electrode. It should be noted that all subsequent voltage values are always referenced to the $\mathrm{Ag} / \mathrm{AgCl}$ reference electrode. A peristaltic pump (Model 7518-60 (driver model 7521-50), Cole Parmer Instrument Company, Vermont Hills, IL) was used to transport the aqueous uranium solution through the cell at specified flow rates. Samples were taken at various times that were predetermined according to the type of experiment being performed. These experiments are discussed in the following section. The voltage was monitored during the experiments by means of a digital voltmeter (Keithly 2700 multimeter/data acquisition system, Integra Series, Keithly Instruments, Inc., Cleveland, $\mathrm{OH}$ ) to ensure that it remained constant and that the reference electrode was operating properly. Both the $\mathrm{pH}$ and the electrical current drawn throughout the experiment (Range doubler multitester, catalogue no. 22-215, Radio Shack) were also recorded in an attempt to gain an understanding of the adsorption mechanism. A photograph of the setup is shown in Figure 4-2.

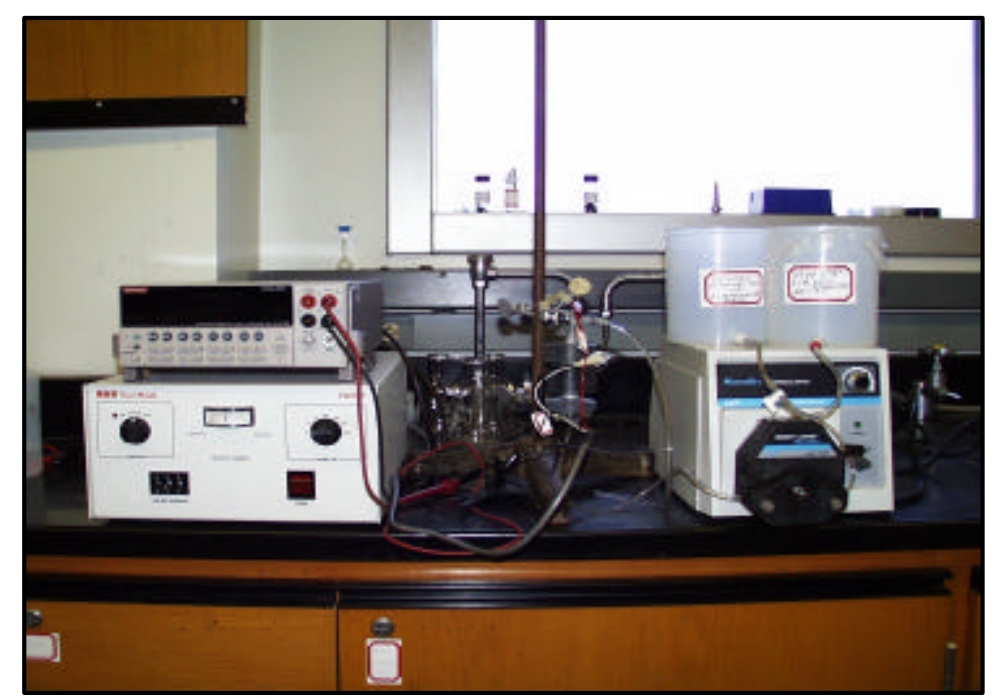

Figure 4-2. Experimental Setup Showing Potentiostat, Voltmeter, Cell, and Peristaltic Pump

It is both interesting and important to note that it is imperative that the cell be fed in the manner indicated by Figure 4-1 (i.e., the feed should come into contact with the working electrode prior to coming into contact with the auxiliary electrode). When the direction is reversed, the process becomes ineffective. This infers that the reaction 
occurring at the auxiliary electrode taints the reaction that occurs at the working electrode.

\subsection{Experiments and Sampling Techniques}

Several different types of experiments were performed in gathering the data presented in Chapter 5 including performance experiments, parameter evaluation experiments, and experiments to determine capacity and possible deterioration of removal efficiency following reloading of the fibers after stripping. The first of these experiments, the performance experiments, were all conducted in the same manner. The fibers were loaded into the cell and wetted with a $0.1 \mathrm{M} \mathrm{KNO}_{3}$ solution. A potential of $+1.0 \mathrm{~V}$ was then applied to the cell while passing the $\mathrm{KNO}_{3}$ solution through at 0.7 $\mathrm{mL} / \mathrm{min}$ for one hour to rinse the fibers. Following this hour, the solution was switched to the 100-ppm uranyl nitrate solution and the effluent was monitored to determine when the uranium solution had displaced the original $\mathrm{KNO}_{3}$ solution. Once the effluent reached $100 \mathrm{ppm}$, the potential was switched from $+1.0 \mathrm{~V}$ to $-0.9 \mathrm{~V}$ and sampling commenced. Samples were taken every fifteen minutes for the first two hours and less frequently thereafter. The flow rate was maintained at $0.7 \mathrm{~mL} / \mathrm{min}$ for the duration of the experiment. Residence time is more indicative of the effectiveness of the fibers; however, it is difficult to determine due to the nature of the experiment. Not only is the free volume inside the cell dependent upon the density of the fiber placed inside, this volume is constantly decreasing as uranium is deposited. In view of these complications, residence times are estimated to be between 5 to 7 minutes.

It should be noted that due to this low flow rate, a 15-minute sampling period was required to obtain the $10-\mathrm{mL}$ sample needed to analyze for uranium. Therefore, the results are reported using average sampling times as opposed to the time that the collection of the sample was actually completed. For the majority of the data, this is would have little effect on the results; however, the first and possibly the second data points are actually elevated due to the high initial concentration of the effluent.

The second set of experiments was performed using the baseline fiber from the initial study involving the performance experiments, PR-1-ox400. This fiber was used to conduct all further testing. The experiments involved varying parameters and included testing several cell potentials, flow rates, and pHs. These experiments were designed to 
be only two hours in length as the interesting phenomena typically occur during the first 30 to 60 minutes of the experiments. The test of cell potential involved testing potentials starting from zero (pure adsorption) and slowly decreasing to $-0.9 \mathrm{~V}$. The evaluation of flow rate involved the use of flow rates 2, 2.5, and 3 times that of the original flow rate. Finally, several pHs were investigated in addition to the original of 3.5. These included 2.0, 5.0, and 7.0. Unless otherwise noted, all experimental parameters with the exception of the one being tested were kept constant and equal to those used during the performance experiments. Samples were taken every fifteen minutes until steady-state effluent concentrations were obtained and less frequently thereafter.

The final experiments involved the effect of stripping and reloading on removal efficiency and the ultimate capacity of the fibers. The cyclic loading experiment utilized the same carbon sample which was repeatedly loaded for two hours and stripped for 30 minutes, then reloaded. The process was repeated six times and samples again were taken every fifteen minutes until steady-state concentrations were reached and less frequently thereafter.

The determination of ultimate capacity involved the use of a 1,000-ppm solution as opposed to 100-ppm used for the abovementioned experiments. The solution was fed at $0.7 \mathrm{~mL} / \mathrm{min}$. Once again, samples were taken every fifteen minutes until a steady-state concentration was achieved and less frequently thereafter. Due to the length of this experiment, it is possible that several hours passed between certain samples. However, due to the nature of the experiment and the performance of the fibers, this did not effect the interpretation of the results nor hinder the experiment in any way.

\subsection{Analytical Methods}

Differential pulse voltammetry (DPV) was employed to analyze the concentration of uranium in the cell feed and effluent. The device consisted of a static mercury drop electrode (SMDE) (Model 303A, EG\&G Instruments, Princeton Applied Research, Princeton, NJ), a potentiostat/galvanastat (Model 263 A, EG\&G Instruments, Princeton Applied Research, Princeton, NJ), and electrochemical software (Model 250, EG\&G Instruments, Princeton Applied Research, Princeton, NJ).

Each 10-mL sample was placed into the measuring cell and purged for four minutes with nitrogen as the presence of oxygen in the sample interferes with the analysis 
of the uranium. The voltage scan began at $-0.5 \mathrm{~V}$ and increased to $0.0 \mathrm{~V}$ at a scan rate of $10.0 \mathrm{mV}$ per second (versus $\mathrm{Ag} / \mathrm{AgCl}$ reference electrode). Uranium (VI) was reduced to $\mathrm{U}(\mathrm{V})$ during the scan causing a current peak to appear at approximately $-0.17 \mathrm{~V}$ (versus $\mathrm{Ag} / \mathrm{AgCl}$ reference electrode). This agrees with the information presented in Chapter 3, which states that the reduction of $\mathrm{U}(\mathrm{VI})$ to $\mathrm{U}(\mathrm{V})$ occurs at $0.052 \mathrm{~V}$. After accounting for the use of the reference electrode, which deducts $0.22 \mathrm{~V}$ from what should be observed, the peak should occur at $-0.168 \mathrm{~V}$.

The height of the peak is proportional to the concentration of U(VI) present in the sample and can be used to determine the amount of U(VI) remaining in solution. A typical U(VI) voltammogram is shown in Figure 4-3. Separate calibration curves were constructed for use in both high and low concentration ranges. As stated above, the calibration curves were constructed prior to testing and are shown below as Figures 4-4 and 4-5. It should be noted that the current peak can shift as the $\mathrm{KCl}-\mathrm{AgCl}$ solution in the reference electrode is diluted through diffusion. The solution was therefore changed regularly (RDE0022, EG\&G Instruments, Princeton Applied Research, Princeton, NJ).

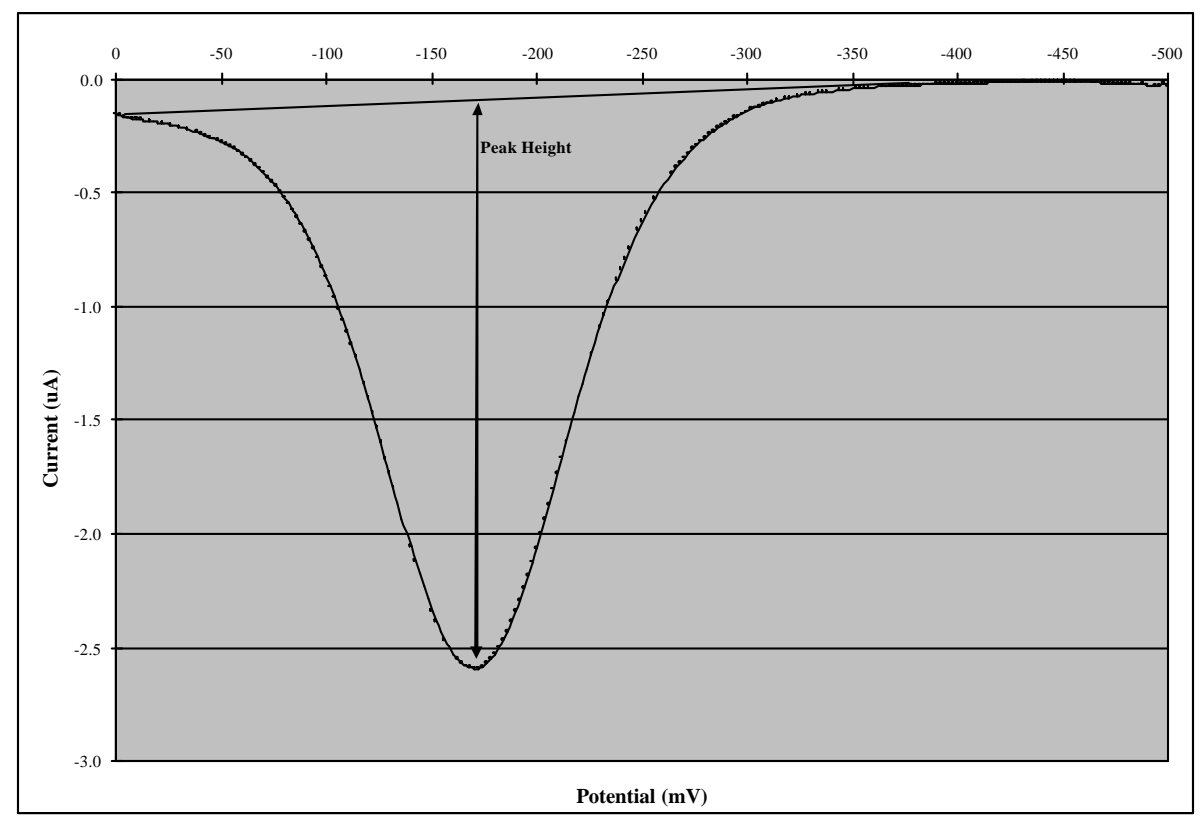

Figure 4 - 3. Typical Voltammogram from DPV Analysis of U(VI) 


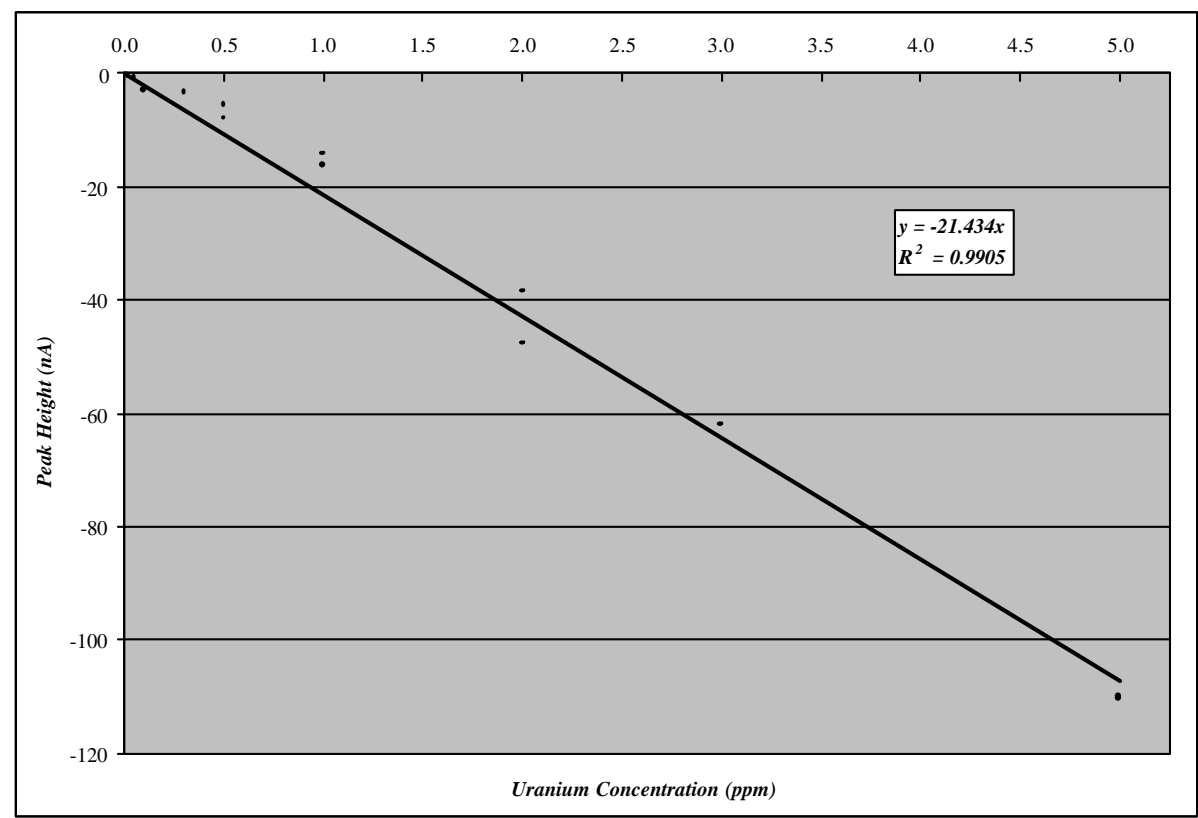

Figure 4-4. Calibration Curve for the Concentration Range 0.0 to $5.0 \mathrm{ppm}$

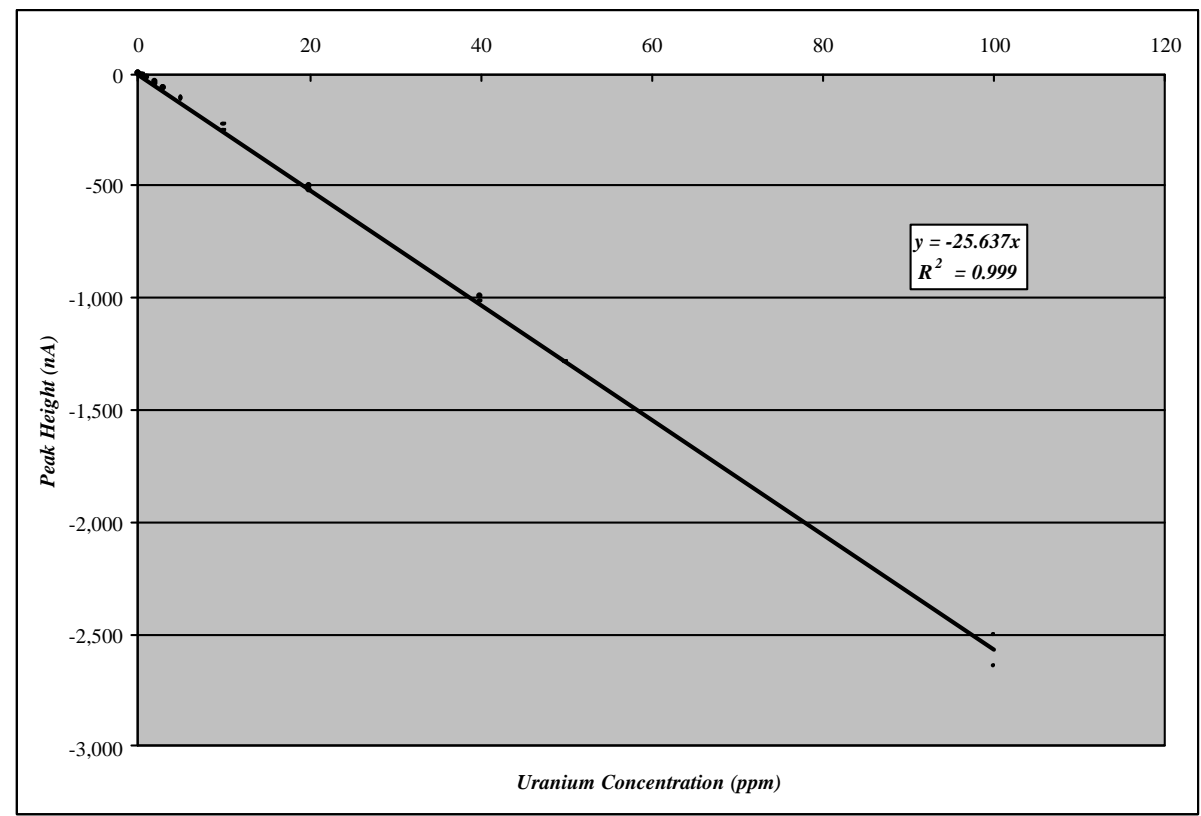

Figure 4-5. Calibration Curve for the Concentration Range 5.0 to $100.0 \mathrm{ppm}$

\subsection{Fiber Unloading}

The fibers can also be stripped of uranium by feeding a $0.1 \mathrm{M}$ potassium nitrate solution through the cell in the same direction as that of the uranium solution and 
applying a positive potential of $+1.00 \mathrm{~V}$ (versus a $\mathrm{Ag} / \mathrm{AgCl}$ reference electrode). The uranium was recovered as a bright yellow solid. Although the form of the solid has been identified as a hydrate, little information is known about its exact structure. It is worth restating that it is this phenomenon that makes this technology unique when compared to current treatment methods. Despite the industry's current ability to concentrate uranium wastes, thereby drastically reducing their volume, an emerging technology such as this provides a means by which the uranium can be recovered in the solid form. This process also provides an advantage to those already treating uranium with anion exchange (i.e., Fernald, Ohio, mentioned previously) as it can be used to treat the high concentration of regenerants obtained after elution.

\subsection{FT-IR and X-Ray Diffraction Analyses}

As stated in the research goals, it is desirable to attempt to assess the nature and amount of oxygen functionality on the surface of the carbon nanofibers. This was attempted through the use of infrared analysis. An FT-IR analyzer was employed to make these measurements (Nicolet 510P FT-IR Spectrometer). The samples were

prepared by mixing various amounts of fiber with $\mathrm{KBr}$ to form a pellet. The amount of fiber in the pellets varied from a maximum of $5 \%$ (by weight) to amounts too small to record.

X-ray diffraction analyses were also performed in an attempt to determine the form of the solid uranium precipitate obtained upon stripping the fibers. An x-ray diffraction unit (Phillips, Model PW1800) using $\mathrm{Cu} \mathrm{K}_{a}$ single-crystal monochromed radiation was utilized. The data were collected in the step-scan mode with a 0.02 degree, 2è step with a measurement time of 0.5 seconds per step. The samples were scanned for 2è values ranging from 5 degrees to 75 degrees. A computer file database (JCPDS International Centre for Diffraction Data) compared the results to characteristics of known compounds to identify the exact species of the uranium solid. 


\section{CHAPTER 5}

\section{RESULTS AND DISCUSSION}

ASI produced eight types of nanofibers with varying physical properties for testing at WVU. After the completion of initial testing, two additional fibers were also fabricated and incorporated into the testing regime. In an attempt to identify those properties that make the fibers effective in uranium removal, the fibers were initially compared based upon a series of performance experiments. Additional testing to determine the dependence of fiber performance on $\mathrm{pH}$, flow rate, and cell potential then followed these experiments. Finally, a fiber was chosen as a representative sample and used to test for capacity and effects of regeneration on removal efficiency. FTIR analysis to identify surface functional groups on the carbon fibers and X-ray diffraction techniques to identify the solid uranium substance obtained upon stripping were also completed and the results are included.

\subsection{Performance Experiments}

The first two samples tested were PR-1-ox400 and PR-1-ox500. PR-1-ox400 is a reproduction of a fiber previously tested by WVU that successfully removed uranium [4]. Both fibers are produced from methane and oxidized in a stream of hot air, PR-1-ox400 at $400^{\circ} \mathrm{C}$ and PR-1-ox 500 at $500^{\circ} \mathrm{C}$. The oxidation at a higher temperature is believed to be more vigorous, therefore resulting in a higher level of oxygen functionality along with a higher surface area and surface energy. PR-1-ox400, as before, proved to be effective in the removal process; the performance curve is shown in Figure 5-1. All performance runs depict an initial run shown by the solid line and a duplicate run to ensure accuracy shown by the dashed line (data used to construct all results can be found in the Appendix). The plot depicts the concentration of uranium in the effluent of the cell as a function of time on-line. The insert is an expanded plot and shows the details of the concentration for the first 60 minutes of the run. It should be noted that the samples represent an average concentration over the fifteen-minute sample time, not an instantaneous concentration. For all the tests described below, the properties of the uranium feed were maintained constant. The concentration was $100 \mathrm{ppm}$, the flow rate was $0.7 \mathrm{~mL} / \mathrm{min}$. and the $\mathrm{pH}$ was 3.5 for these tests and subsequent tests unless otherwise 
noted. PR-1-ox500 was also effective in uranium removal and the performance curve for this fiber is shown in Figure 5-2.

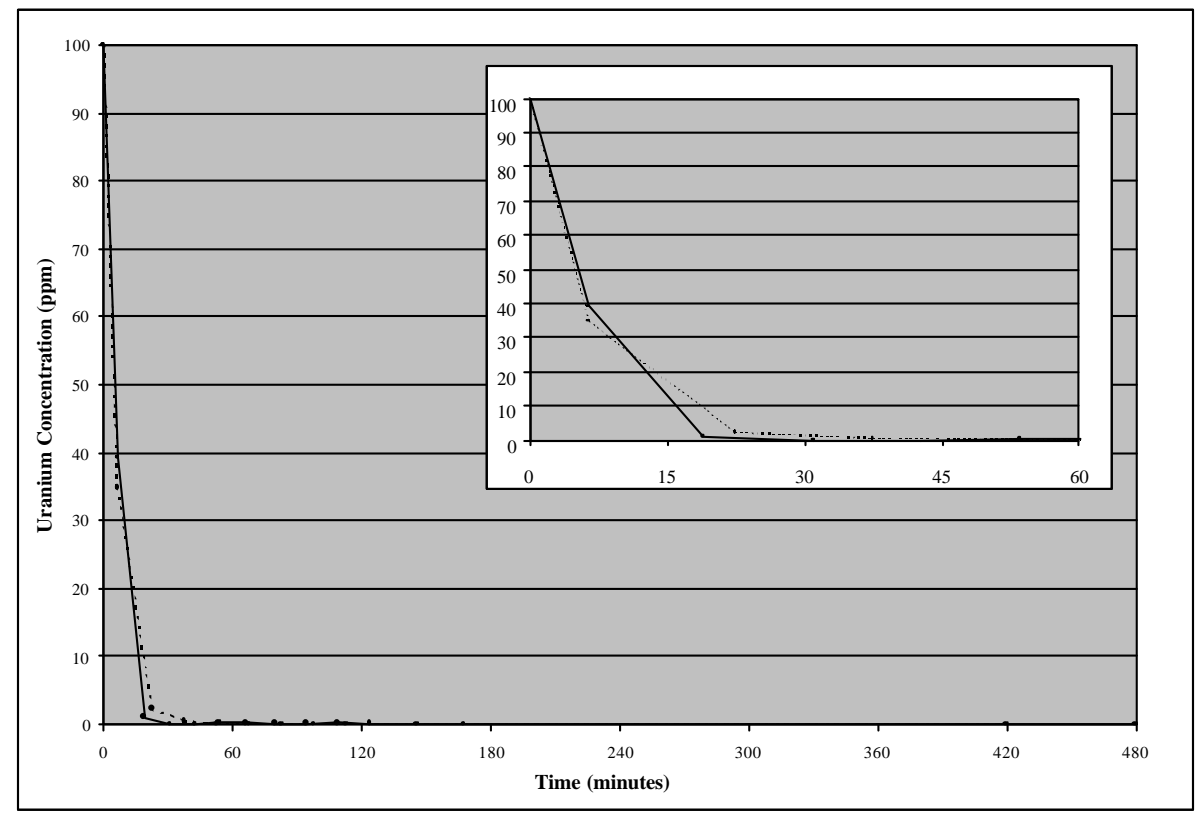

Figure 5 - 1. Performance Curve for PR-1-ox400

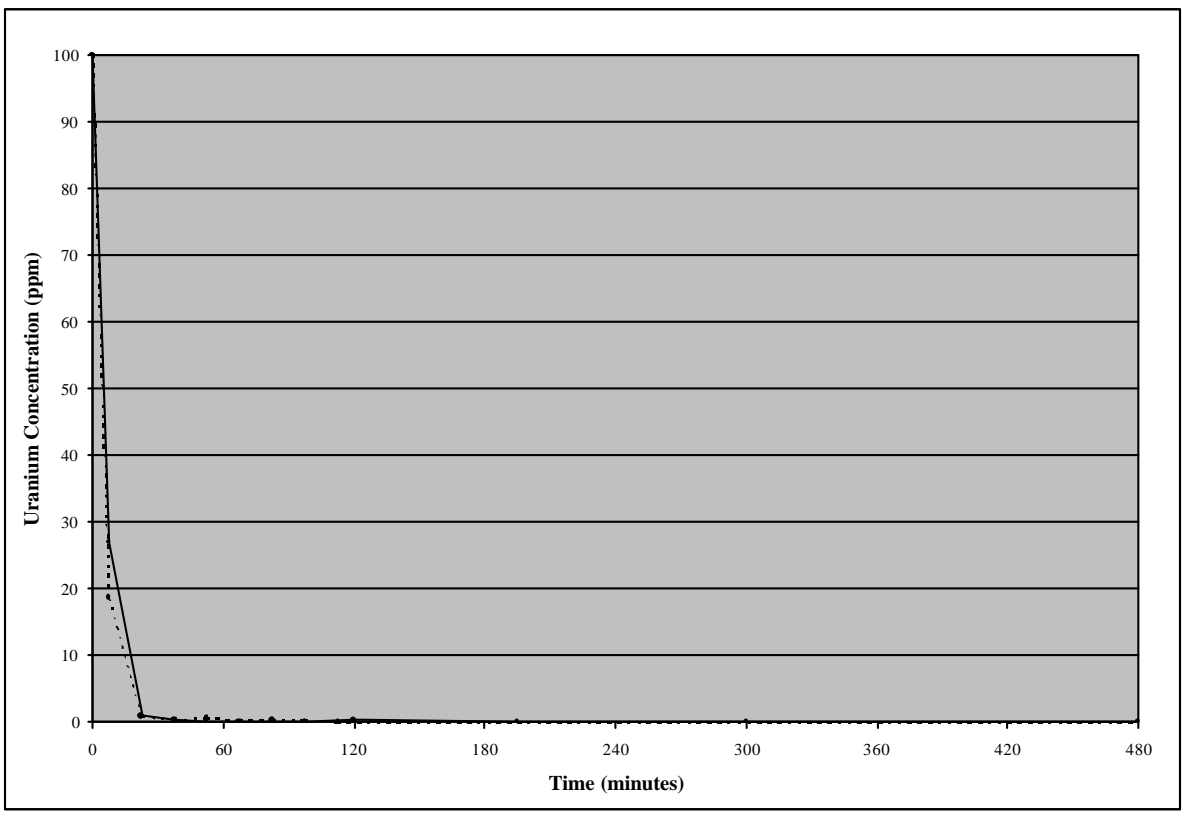

Figure 5 - 2. Performance Curve for PR-1-ox500 
It is also interesting to note the trend of both the current drawn due to the reaction taking place inside the cell throughout the duration of the experiment and the $\mathrm{pH}$ of the effluent. The current and $\mathrm{pH}$ trends are shown in Figures 5-3 and 5-4, respectively. As can be seen from Figure 5-3, the current is initially high and then slowly drops to a steady-state level. In opposition, the $\mathrm{pH}$ initially drops and then slowly rises to a steadystate effluent $\mathrm{pH}$ of approximately 2.8. Although the trend of the two parameters is opposite, both demonstrate a relationship similar to that of the concentration versus time graphs. All parameters demonstrate an initial spike at the onset of the experiment then a constant decrease until a steady-state value is achieved. Because of the similar behaviors that mimic concentration trends, it is likely that changes in both $\mathrm{pH}$ and current are related to the electrosorption mechanism.

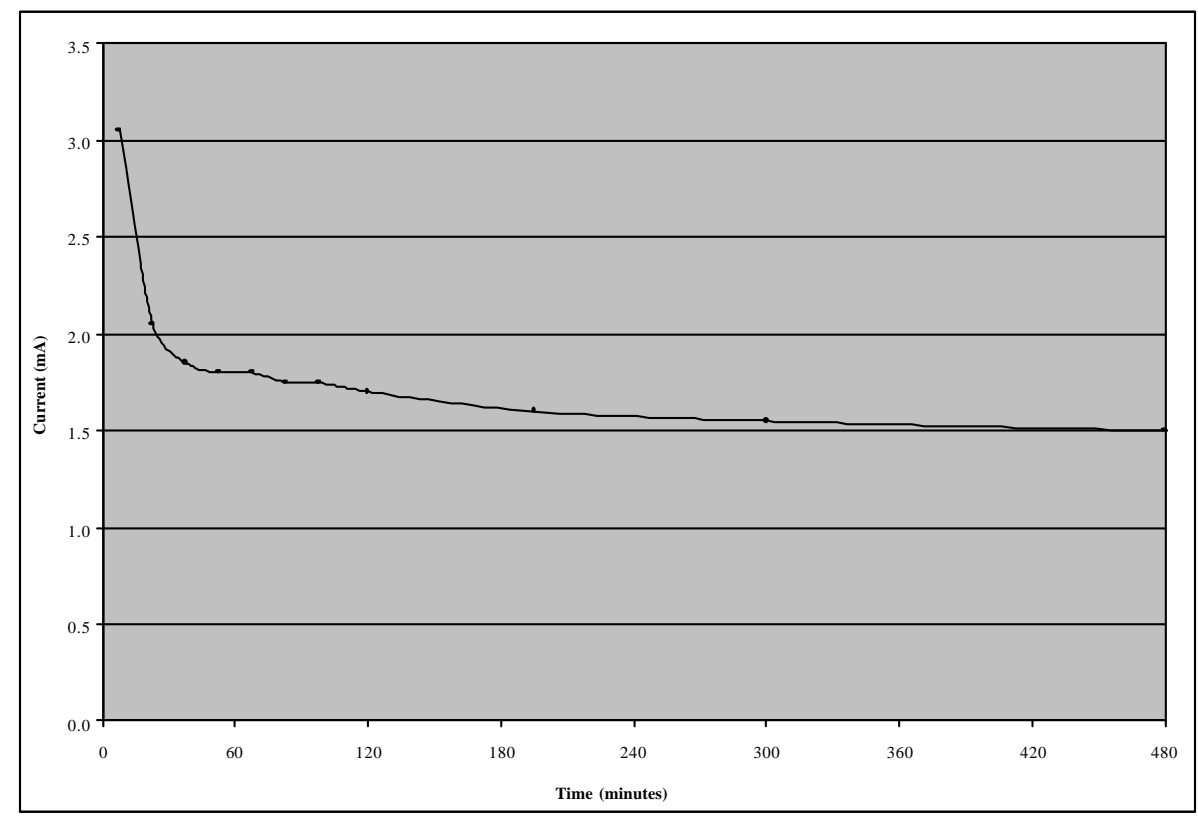

Figure 5 - 3. Representative Behavior of Current throughout the Performance Experiments

The third fiber tested, also an oxidized fiber, was PR-19-ox400 and it performed identically to that of the baseline fiber, PR-1-ox400. This fiber was fabricated identically to that of PR-1-ox400; however, natural gas was used as the carbon source as opposed to methane resulting in a slightly larger diameter. Because both fibers were oxidized in air at $400^{\circ} \mathrm{C}$, they are believed to have the same extent of oxidation on the surface; hence, their identical performance was not unexpected. The results are shown in Figure 5-5. 


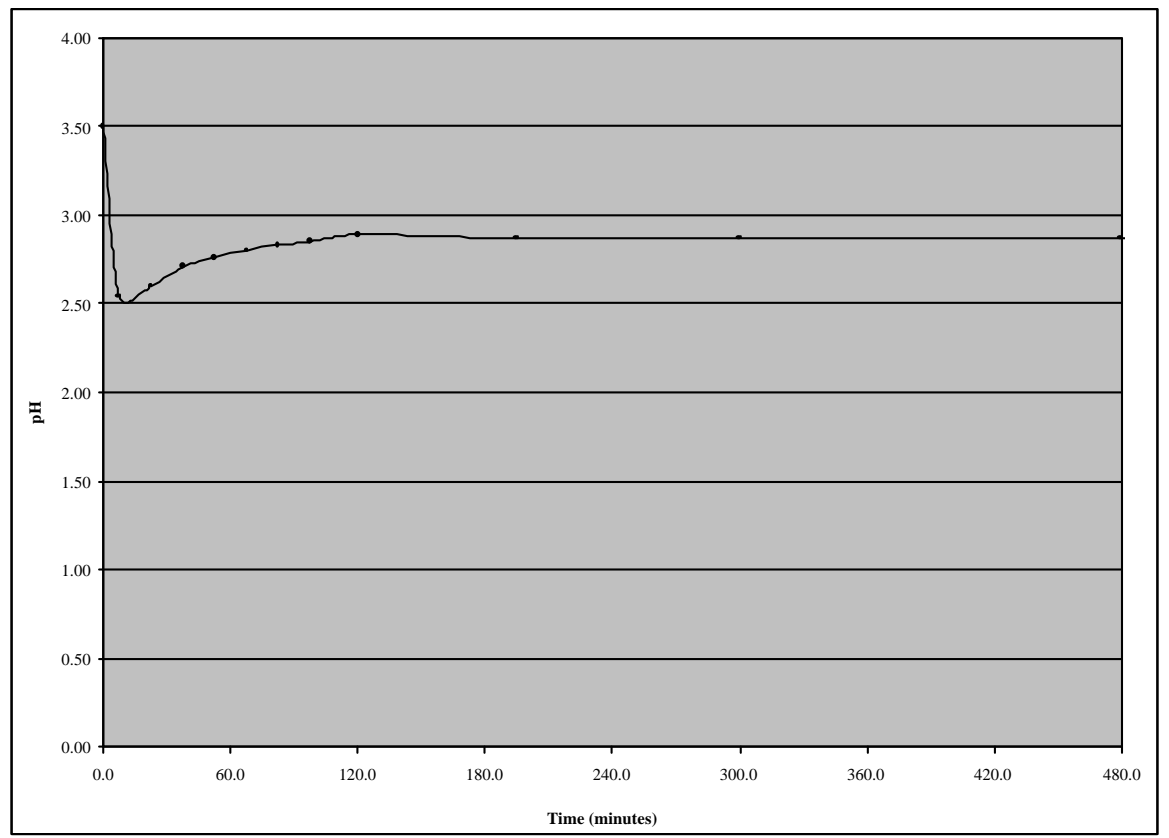

Figure 5 - 4. Representative Behavior of Effluent pH throughout the Performance Experiments

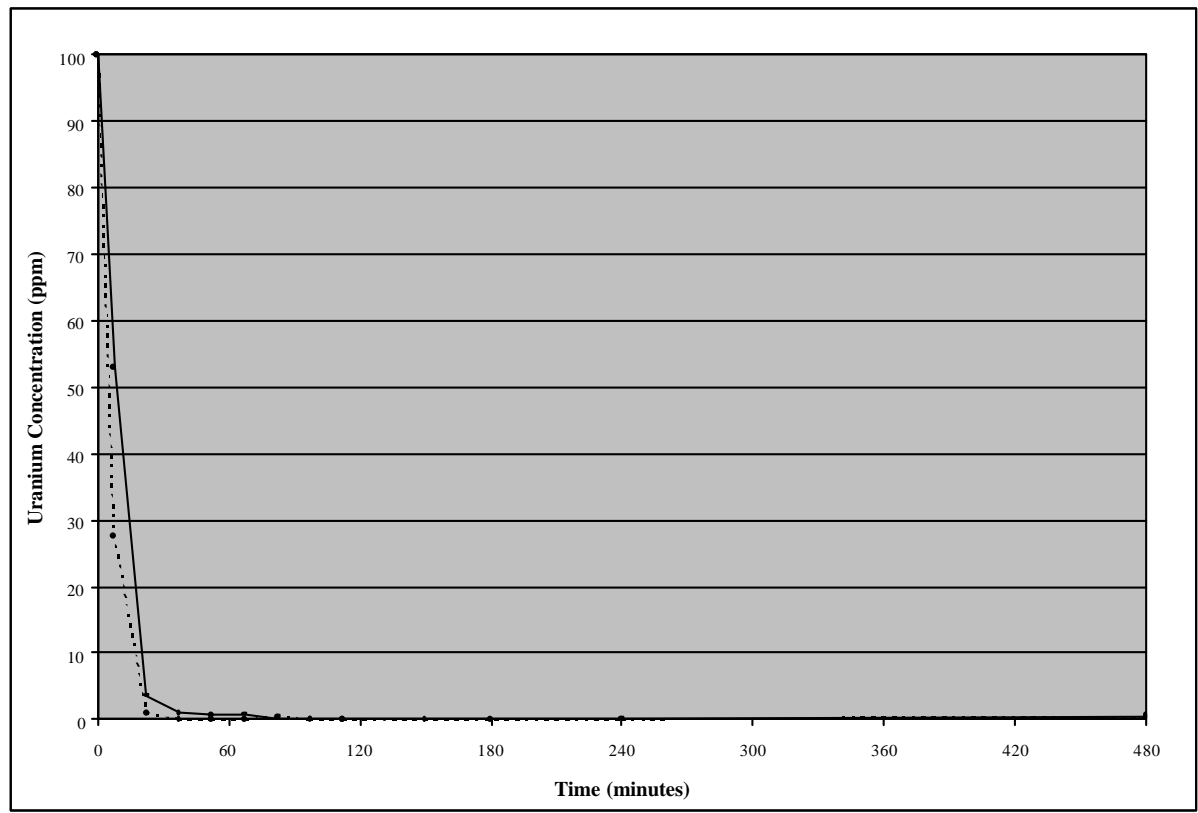

Figure 5 - 5. Performance Curve for PR-19-ox400 
As opposed to the intial set of three fibers which were all oxidized, the second set of fibers tested were unoxidized or "as grown" fibers meaning they underwent no posttreatment processing. This group included two fibers, PR-1-AG and PR-19-AG. PR-1AG was fabricated from methane and PR-19-AG from natural gas. Both fibers were very effective in uranium removal. The results of the performance tests completed using the PR-1-AG and the PR-19-AG fibers are shown in Figures 5-6 and 5-7, respectively.

It should be noted that in previous testing conducted at WVU, the unoxidized fibers prepared and supplied by ASI proved to be unsuccessful [4]. However, when similar fibers were supplied and tested again (PR-1-AG), the fibers proved to be effective in the removal of uranium. The cause of this discrepancy is unknown at this time due to the lack of knowledge of the electrosorption mechanism. It is possible that the fibers changed over time; it is also possible that due to continuing improvements in the production process, an unidentified characteristic was altered, causing the fibers to be more effective (e.g., surface PAH content). Regardless, to ensure the importance of utilizing the fibers provided by ASI, two samples of carbon black were obtained and tested for their effectiveness at uranium removal. The results of these tests are presented at the end of this section.

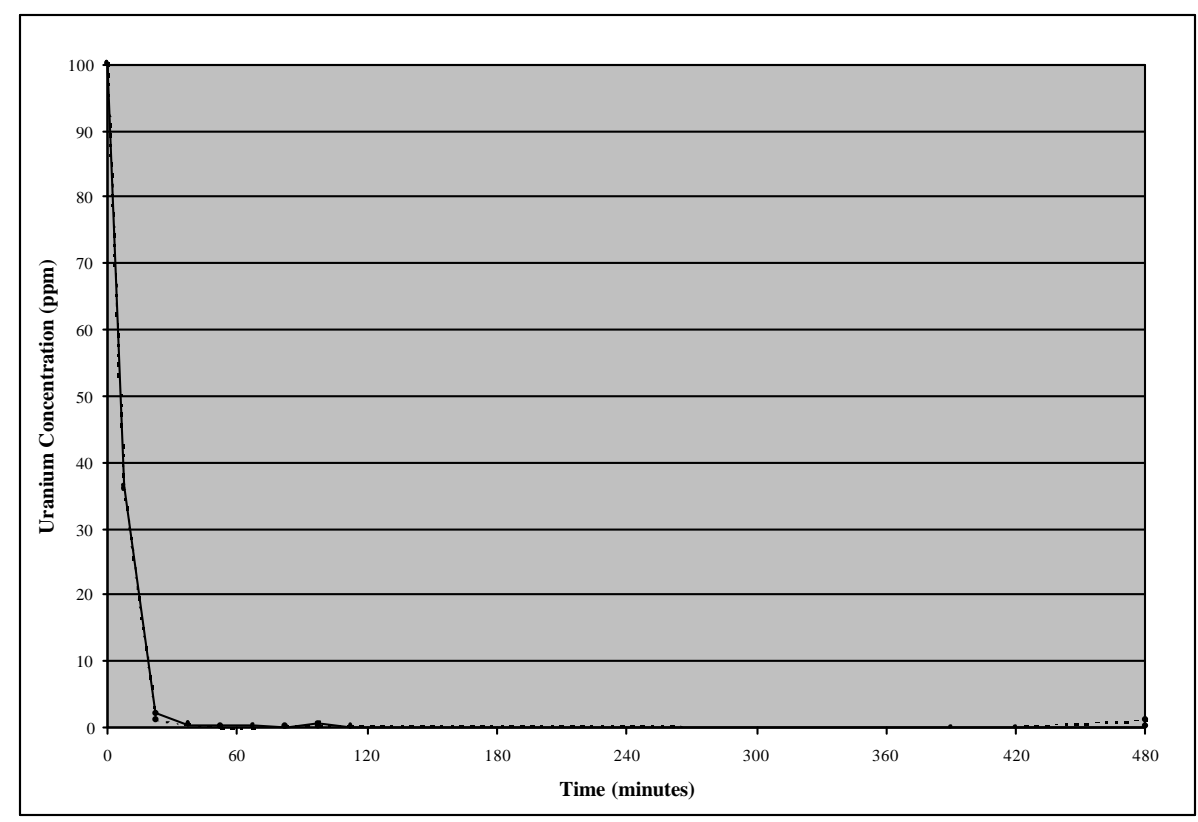

Figure 5 - 6. Performance Curve for PR-1-AG 


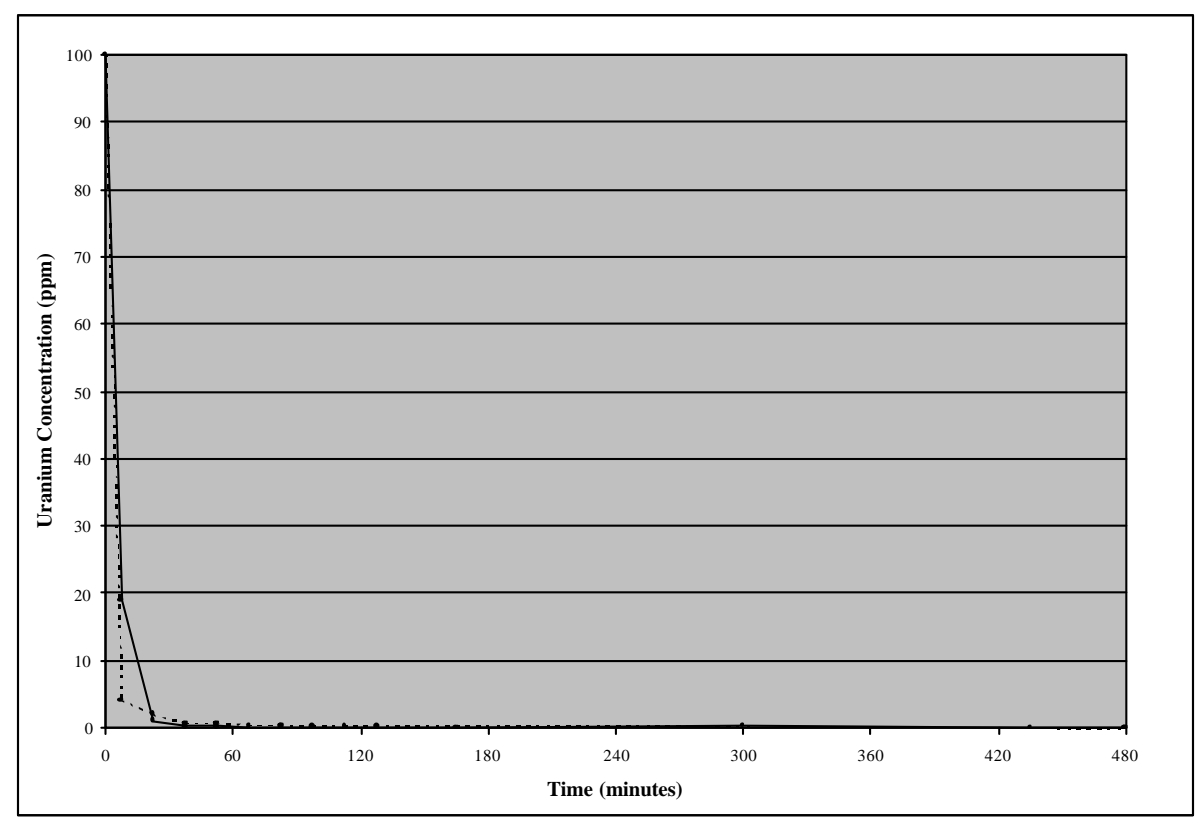

Figure 5 - 7. Performance Curve for PR-19-AG

The next set of fibers tested included the last three fibers initially supplied by ASI including PR-19-HT, PR-21-PS, and $\mathrm{CO}_{2}-950$. The PR-19-HT fiber is a fully graphitized version of PR-19-AG and has a higher surface energy and higher graphitization index than the other fibers. The fibers are heated to above $3,000^{\circ} \mathrm{C}$ in an inert atmosphere for between 1 and 4 hours. It is also possible that the fibers have a higher edge plane density but this has yet to be substantiated. This fiber, like the previous fibers tested, was successful in removing uranium and the results of the testing can be seen in Figure 5-8.

PR-21-PS is a production fiber that has approximately the same diameter as the PR-19-AG fibers but has a higher surface area and surface energy. The fiber is produced using natural gas with an addition of $\mathrm{CO}_{2}$ and the post-treatment involves heating in argon for between 4 and 6 hours. This fiber was also effective in uranium removal, and the results can be seen in Figure 5-9.

The $\mathrm{CO}_{2}-950$ fiber has the highest surface area and surface energy of all the fibers supplied. They performed very well also and the results of this test can be seen in Figure 5-10. 


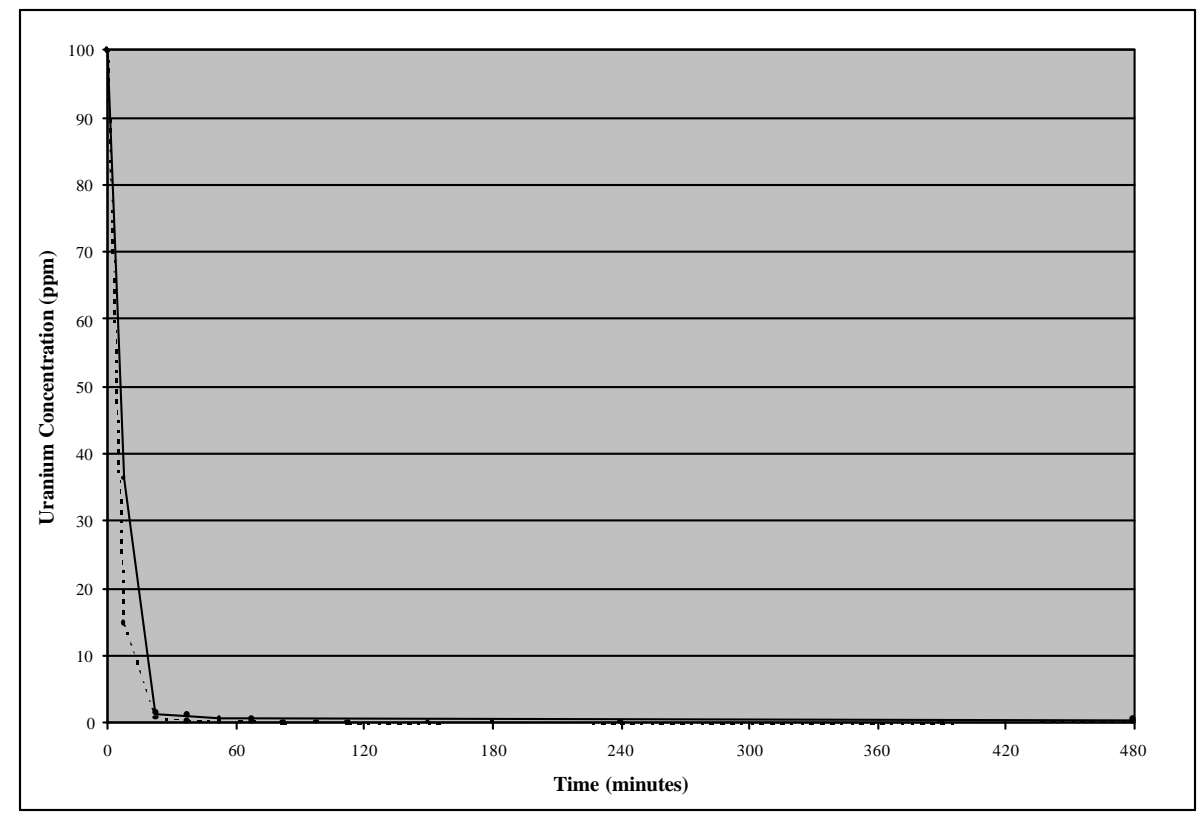

Figure 5 - 8. Performance Curve for PR-19-HT

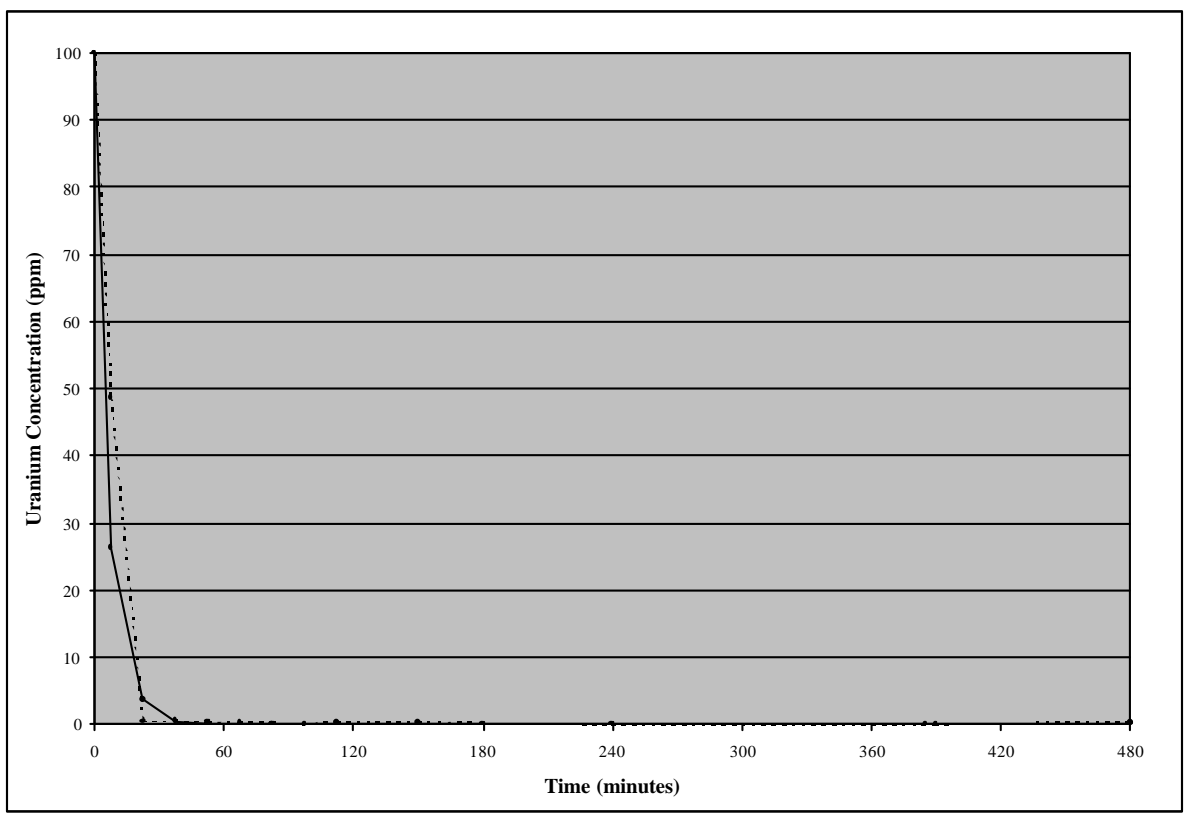

Figure 5 - 9. Performance Curve for PR-21-PS 


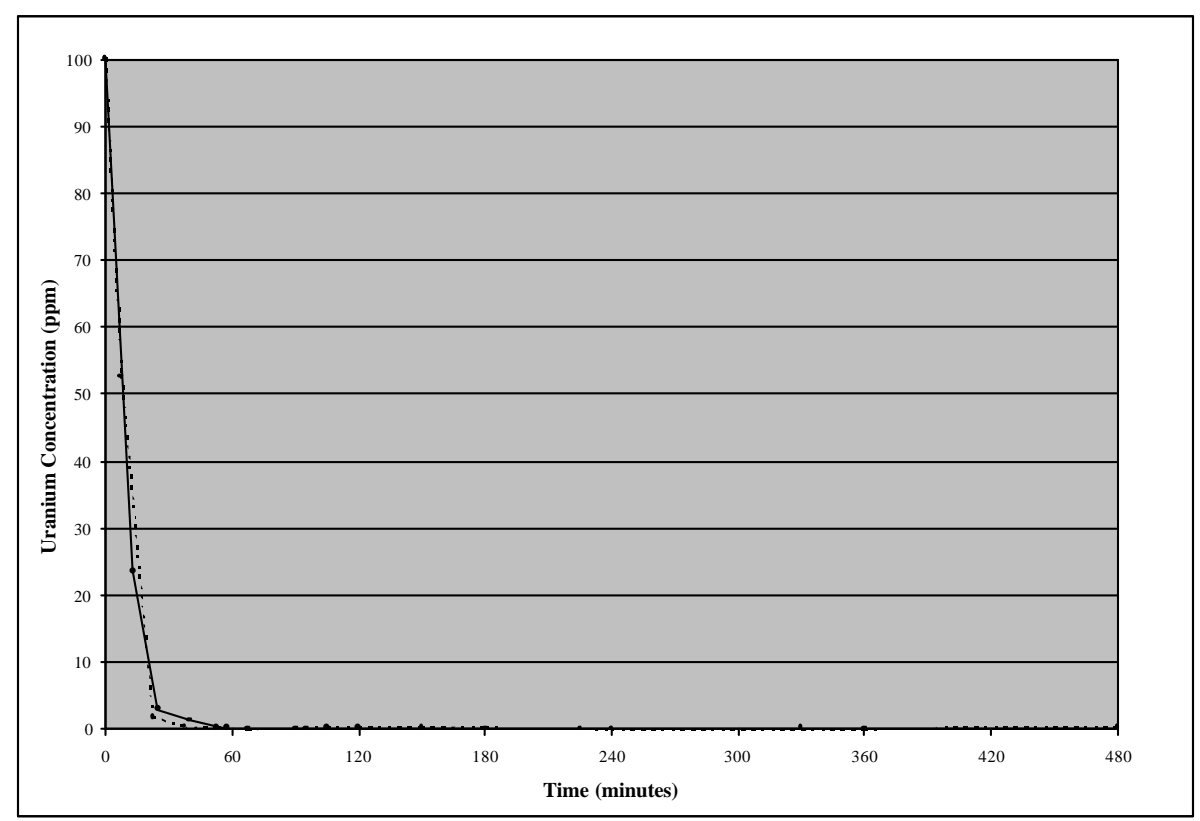

Figure 5 - 10. Performance Curve for $\mathrm{CO}_{2}-950$

The last set of fibers included the two additional fibers not within the original scope of testing. The ninth fiber, PR-23-HT, was similar to the PR-19-HT fiber, but has a smaller diameter and possibly more edge planes. This fiber was just recently developed and was therefore not included in the initial scope of the testing. This fiber, like PR-19$\mathrm{HT}$ is post-treated by heating to above $3,000^{\circ} \mathrm{C}$ in an inert environment. PR-23-HT performed very well and the results are shown in Figure 5-11.

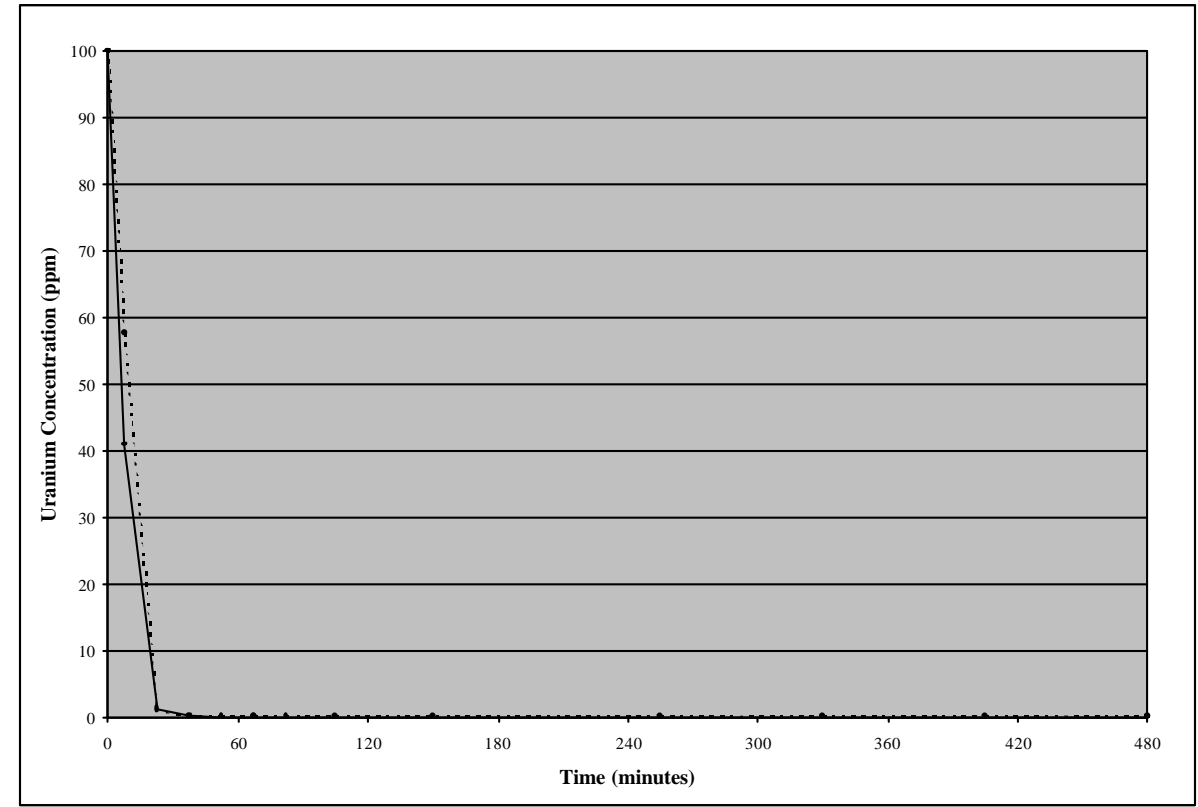

Figure 5 - 11. Performance Curve for PR-23-HT 
The final fiber tested, PR-24, was post-treated by soaking in peracetic acid in a successful attempt (verified by ASI via XPS) to saturate the surface with oxygen functional groups. This fiber also proved to be very effective in the removal of uranium and the results of this test are shown in Figure 5-12.

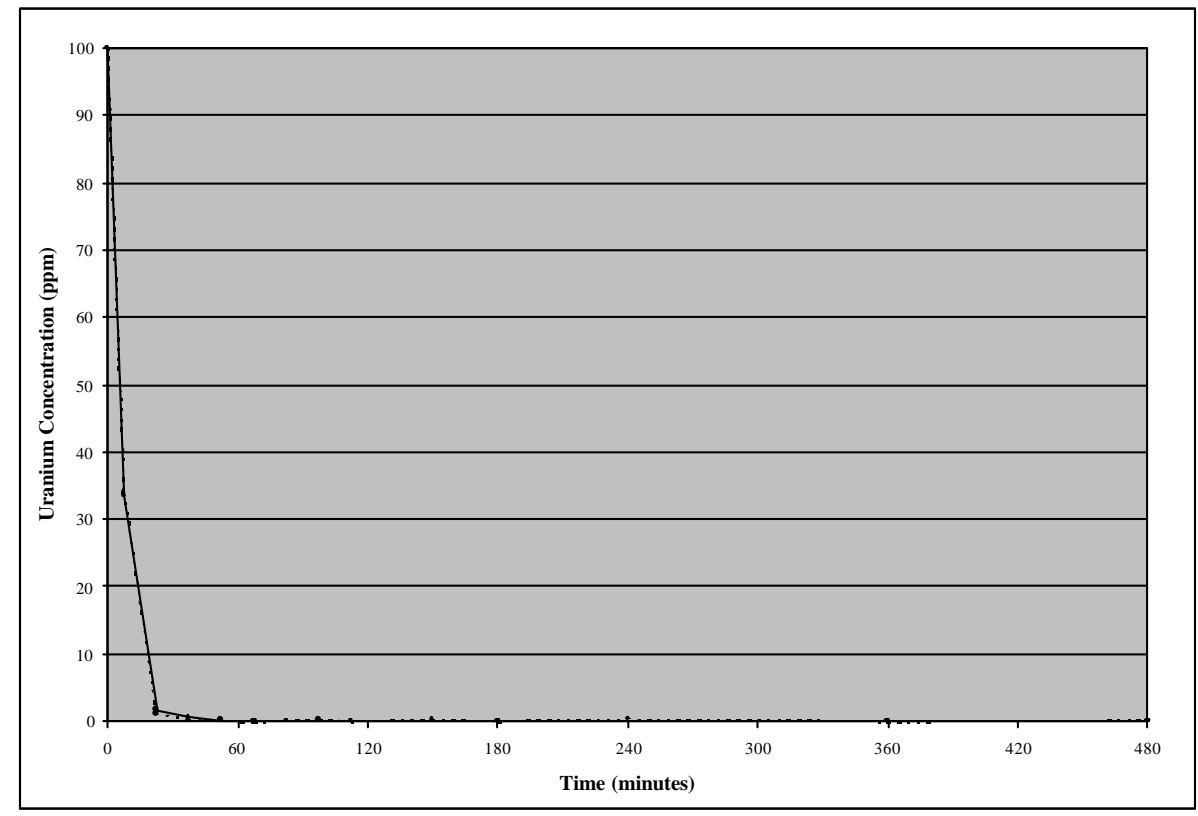

Figure 5 - 12. Performance Curve for PR-24

As stated previously, two samples of carbon black were evaluated to ensure the unique capability provided by using the fibers produced by ASI. The samples obtained were conductive in an attempt to obtain different types of carbon that are nominally used for the same types of applications. The carbon black samples were tested in the same manner as that of the fibers. The first sample, PG-195-XB, was relatively unsuccessful in removing uranium. The concentration initially dropped from $100 \mathrm{ppm}$ to approximately $70 \mathrm{ppm}$ but then began to increase toward the initial 100-ppm concentration of the feed solution in a very short time. Although the sample did remove some uranium, when compared with the fibers it was considered unsuccessful. The second sample, Superior Graphite (BG-34), was more successful than the PG-195-XB. The concentration initially dropped and then increased until reaching a steady state of sorts where it remained for a short time before also increasing toward $100 \mathrm{ppm}$. The results from both experiments are shown in Figures 5-13 and 5-14, respectively. 


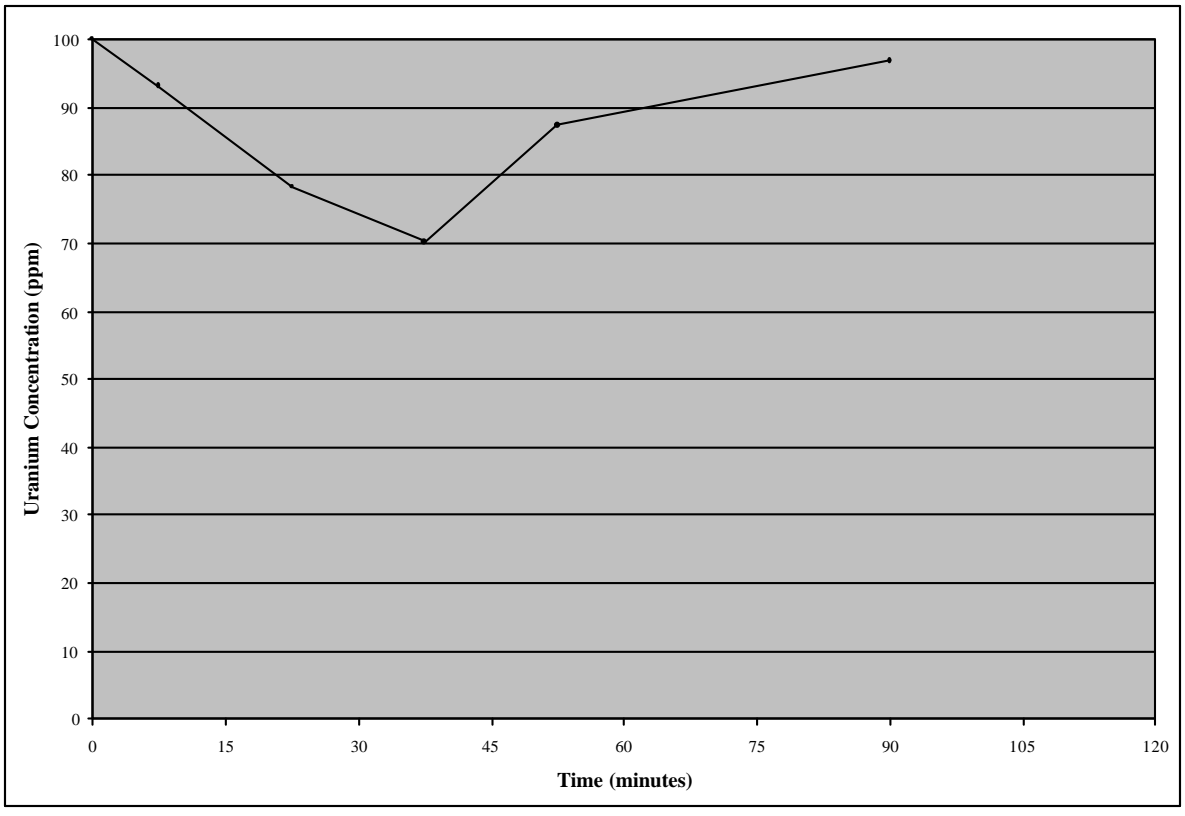

Figure 5 - 13. Performance Curve for PG-195-XB

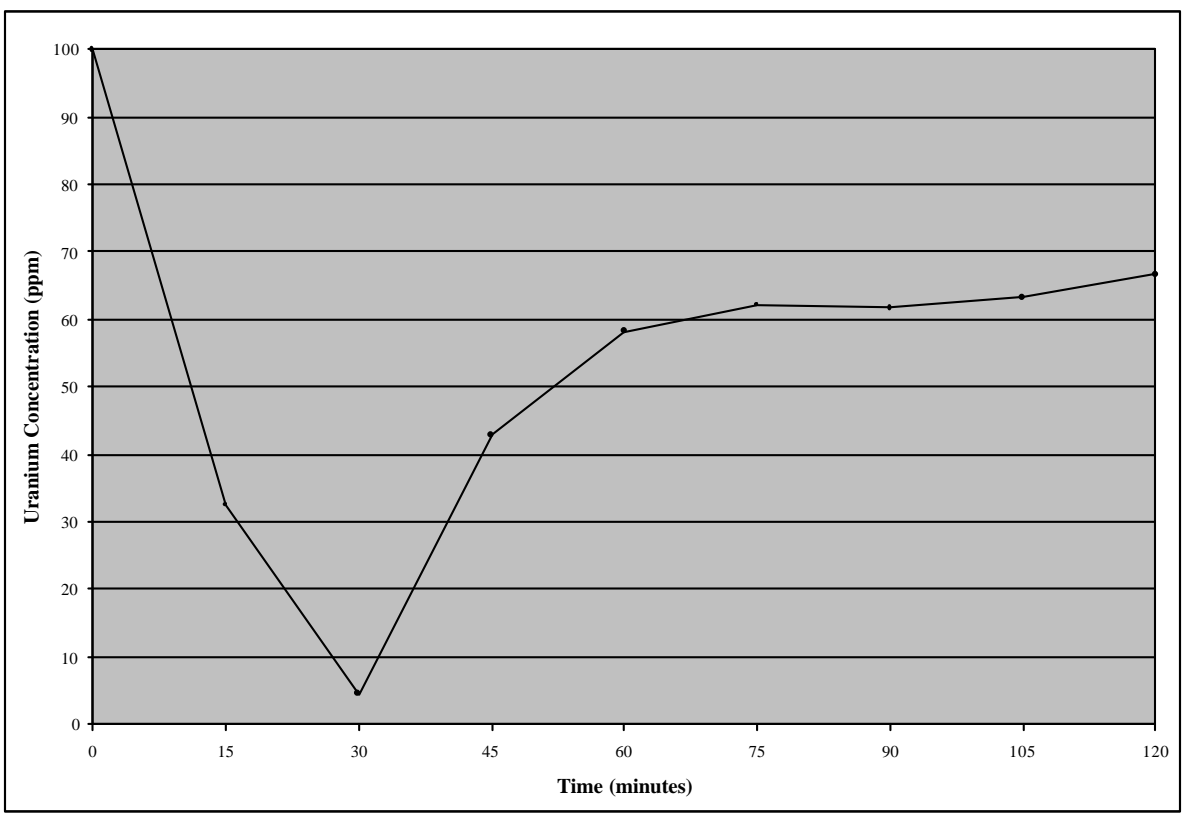

Figure 5 - 14. Performance Curve for Superior Graphite (BG-34) 


\subsection{Effect of Cell Potential on Fiber Performance}

It was both presumed and demonstrated through previous testing that several factors contribute to the effectiveness of the nanofibers including $\mathrm{pH}$, flow rate, and cell potential. The first factor investigated was the potential applied to the electrolytic cell. An experiment was conducted using the baseline fiber (PR-1-ox400) during which the effect of several cell potentials was established. (It should be noted that this is the same fiber used for the remainder of the experiments discussed in this chapter.) The potentials ranged from zero (pure adsorption) to $-0.9 \mathrm{~V}$, the potential applied during the performance experiments discussed in the previous section. The results of the variation in cell potential are shown in Figure 5-15.

The dashed line, which for the most part is constant at $100 \mathrm{ppm}$, represents zero potential and therefore resulted in very little removal. Following the observation of zero potential, both $-0.1 \mathrm{~V}$ and $-0.2 \mathrm{~V}$ were tested and although a small amount of removal was noted during the first fifteen minutes, the uranium concentration in the effluent immediately returned to the inlet concentration of $100 \mathrm{ppm}$. Once the applied potential was increased to $-0.3 \mathrm{~V}$, the fibers became more effective; however, the steady-state effluent concentration still remained between $85 \mathrm{ppm}$ to $95 \mathrm{ppm}$. The major increase in removal efficiency occurred when the potential was raised from $-0.3 \mathrm{~V}$ to $-0.4 \mathrm{~V}$. The effluent concentration initially decreased to below $10 \mathrm{ppm}$ then increased to a steadystate concentration of approximately $15 \mathrm{ppm}$. The final three potentials tested included $-0.5 \mathrm{~V},-0.7 \mathrm{~V}$, and $-0.9 \mathrm{~V}$ all resulted in a steady-state concentration of below $1 \mathrm{ppm}$. It is obvious from this experiment that there is a change that occurs between $-0.3 \mathrm{~V}$ and -0.4 $\mathrm{V}$ at which point the nanofibers become particularly more effective. This phenomenon is most likely due to the required potential associated with the precipitation reaction/s.

It is interesting to look at the relationship between applied potential and steady state effluent concentration in an attempt to predict the limiting potential or potential at which the effluent remains at or below $1 \mathrm{ppm}$. These data are plotted and shown in Figure 5-16. The plot shows that although the most significant change occurs between 0.3 and $-0.4 \mathrm{~V}$, the limiting potential at which the effluent is maintained at or below 1 ppm is between -0.4 and $-0.5 \mathrm{~V}$. 


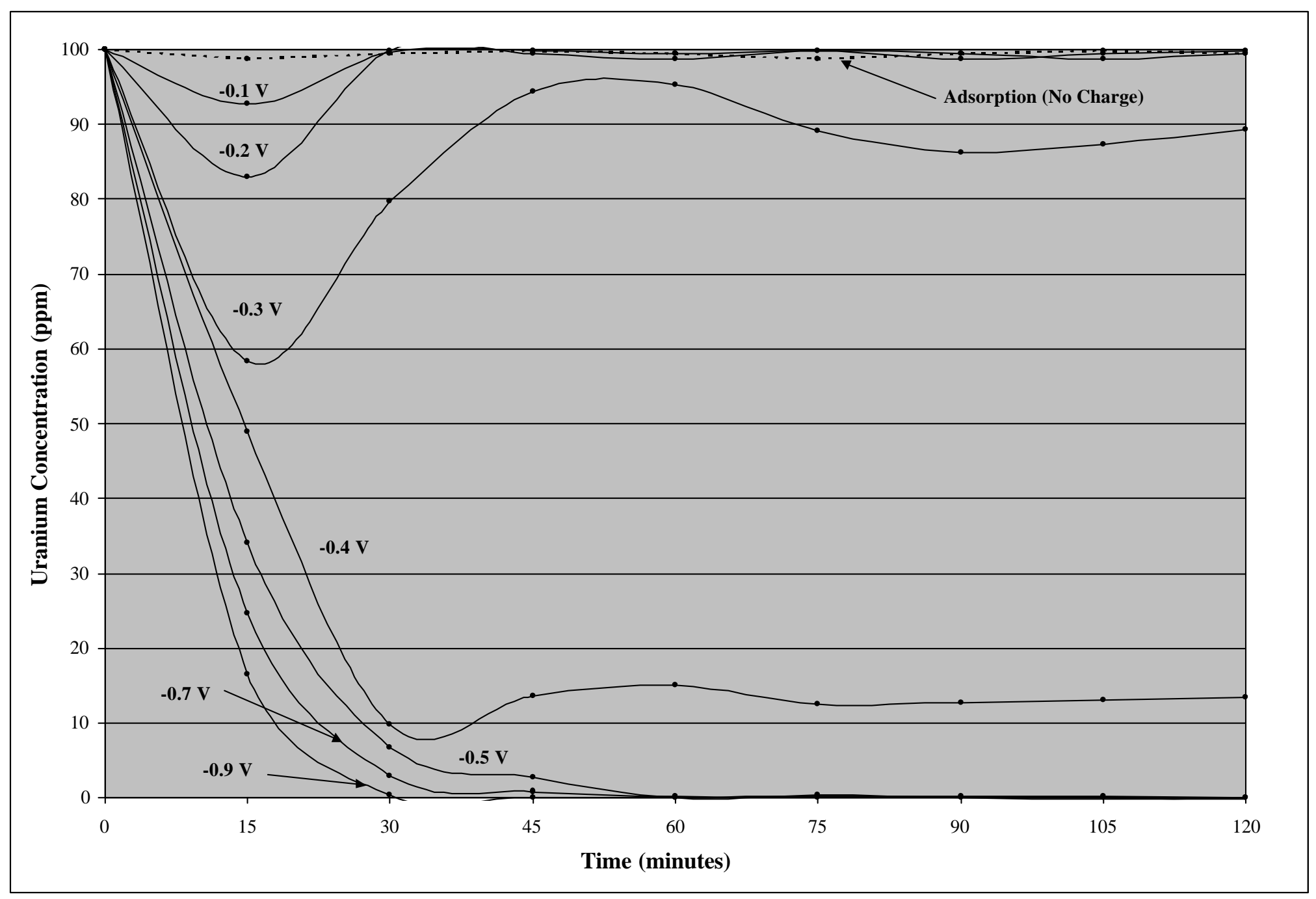

Figure 5 - 15. Effect of Variation in Applied Potential 


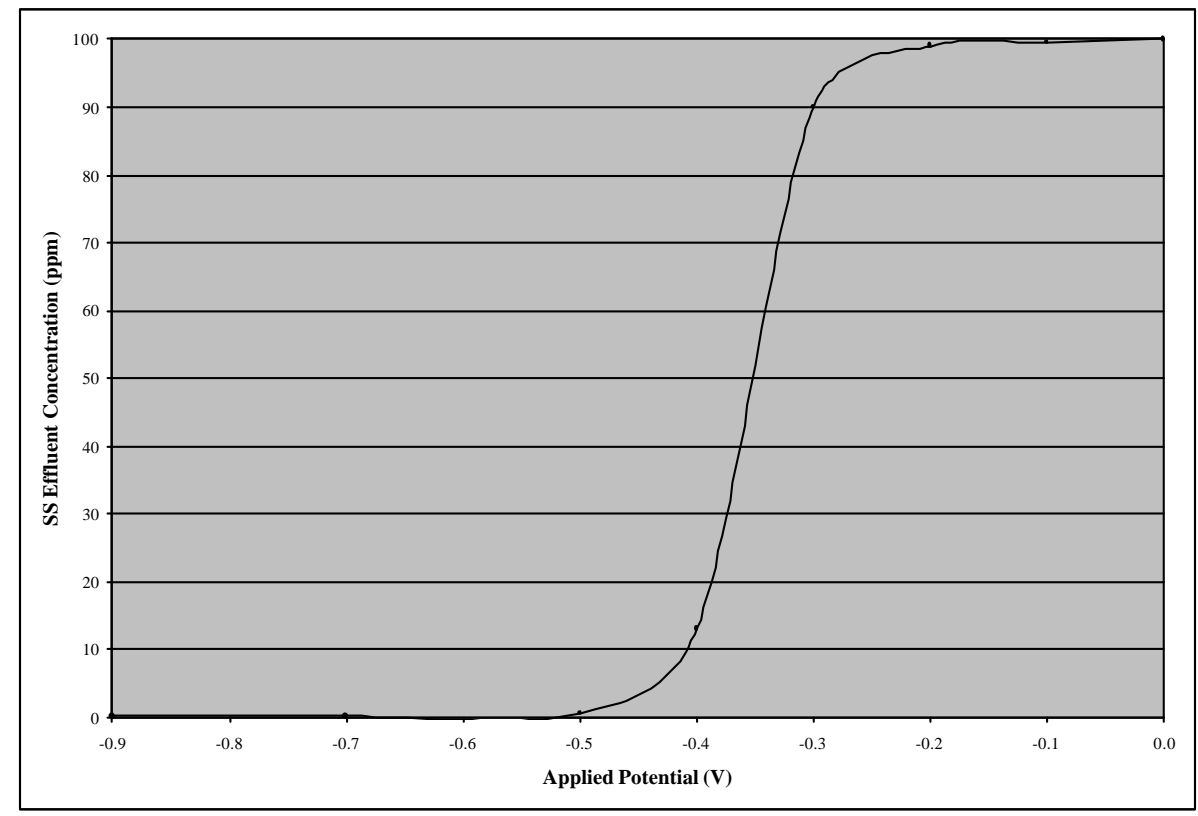

Figure 5 - 16. Effect of Applied Potential on Steady-State Effluent Concentration

\subsection{Effect of Flow Rate on Fiber Performance}

Although previous studies conducted at WVU showed $0.7 \mathrm{~mL} / \mathrm{min}$ (the flow rate used in the performance experiments discussed in Section 5.2) to be the limiting flow rate [4], the experiment was performed again in an attempt to reproduce the results and ensure that the cell was being operated at its maximum throughput potential. The limiting flow rate was determined to be the maximum flow rate at which the cell can be operated while maintaining an effluent concentration of below $1 \mathrm{ppm}$. The results of the experiment are shown in Figure 5-17.

The initial flow rate of $0.7 \mathrm{~mL} / \mathrm{min}$ (equivalent to a residence time of 5 to 7 minutes) is shown by the dashed line. Upon doubling the flow rate to $1.4 \mathrm{~mL} / \mathrm{min}$ (residence time of 2.5 to 3.6 minutes), the performance of the fiber (PR-1-ox400) was not compromised; however, once the flow rate of the influent was tripled to $2.1 \mathrm{~mL} / \mathrm{min}$ (residence time of 1.9 to 2.8 minutes), the fibers were no longer as effective and the effluent concentration remained slightly above $15 \mathrm{ppm}$ for the duration of the experiment. Finally, a flow rate two and a half times that of the initial flow rate, approximately 1.8 $\mathrm{mL} / \mathrm{min}$ (residence time of 1.7 to 2.4 minutes) was tested. This flow rate resulted in a steady-state effluent concentration of about 5 ppm. 


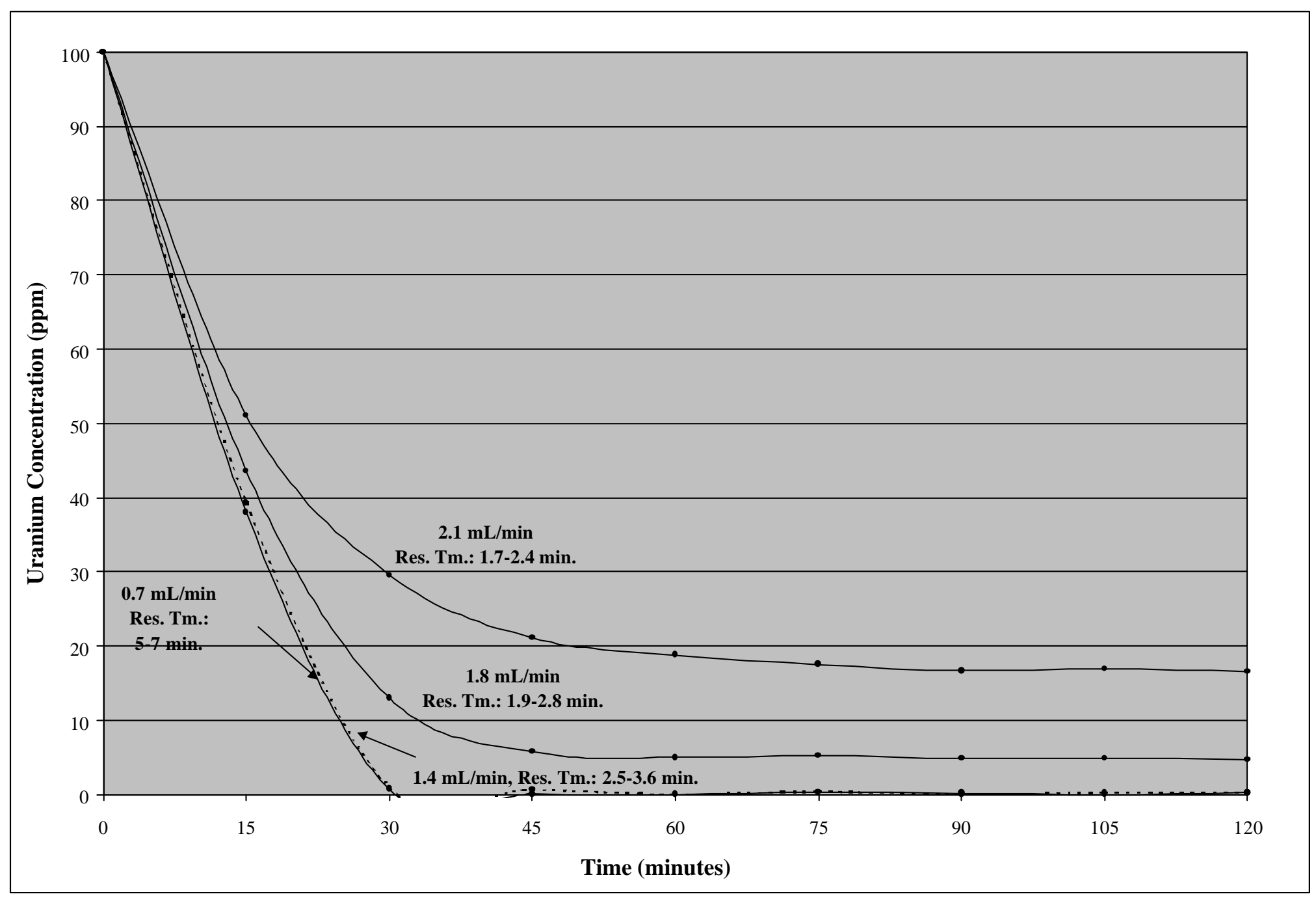

Figure 5 - 17. Effect of Variation of Flow Rate 
Although it can be deduced from Figure 5-17 that the limiting flow rate occurs between 1.4 and $1.8 \mathrm{~mL} / \mathrm{min}$, a separate plot was constructed in an attempt to predict the exact value and is shown in Figure 5-18. The data were determined to have an exponential relationship and predict a limiting flow rate of approximately $1.5 \mathrm{~mL} / \mathrm{min}$. It should be noted that this fiber is a representative sample and it is likely that the limiting flow rate would vary from fiber to fiber. It is also a strong function of cell size and geometry.

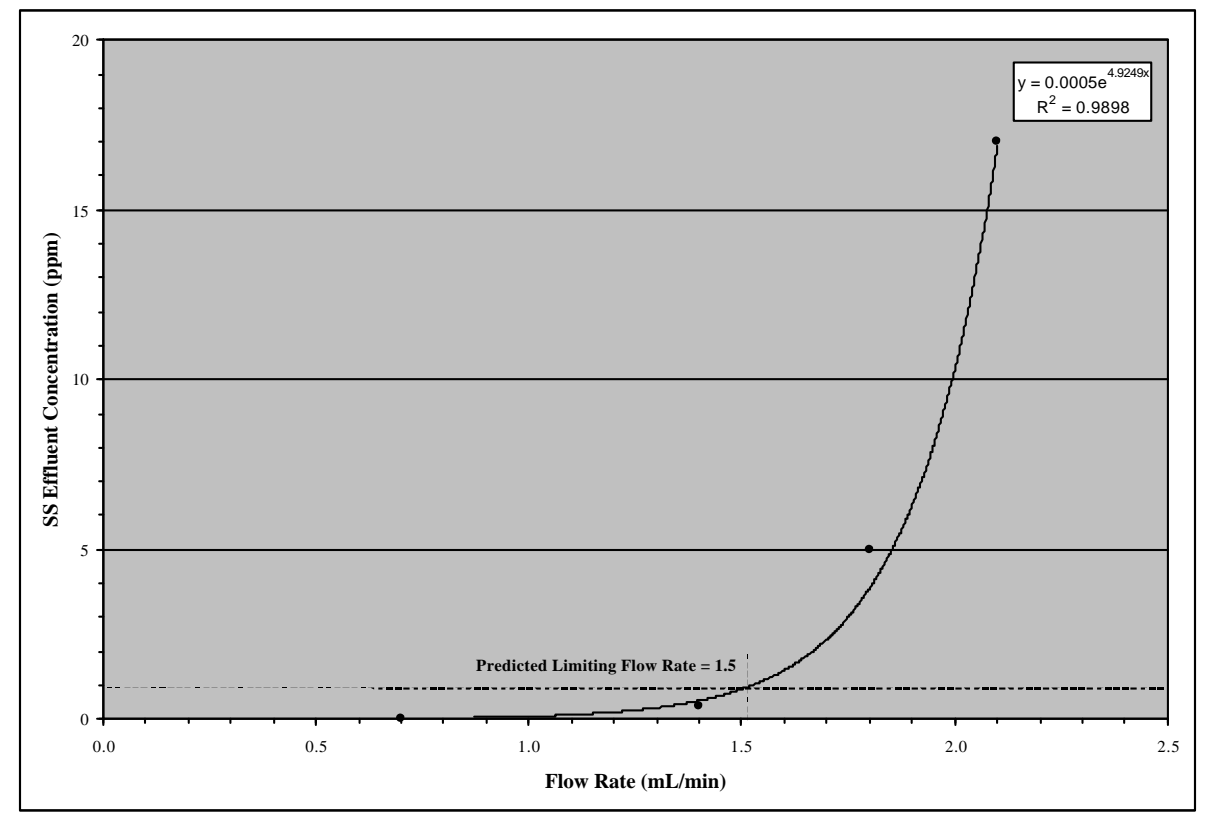

Figure 5 - 18. Limiting Flow Rate Determination Through Evaluation of SteadyState Effluent Concentrations

\subsection{Effect of pH on Fiber Performance}

The final parameter tested was $\mathrm{pH}$. The $\mathrm{pH}$ in nearly all of the performance experiments was 3.5 in an attempt to mimic the previous studies conducted at WVU [4]. These prior studies showed that at a $\mathrm{pH}$ of 2.0 no removal occurred while for $\mathrm{pHs}$ above 3.5 the performance of the fibers increased remarkably. For this study, pHs of 2.0, 5.0, and 7.0 were tested in addition to the known performance at a $\mathrm{pH}$ of 3.5. The results of the experiment are shown in Figure 5-19 where the dashed line notes the performance at a $\mathrm{pH}$ of 3.5 and additional $\mathrm{pHs}$ are indicated. 


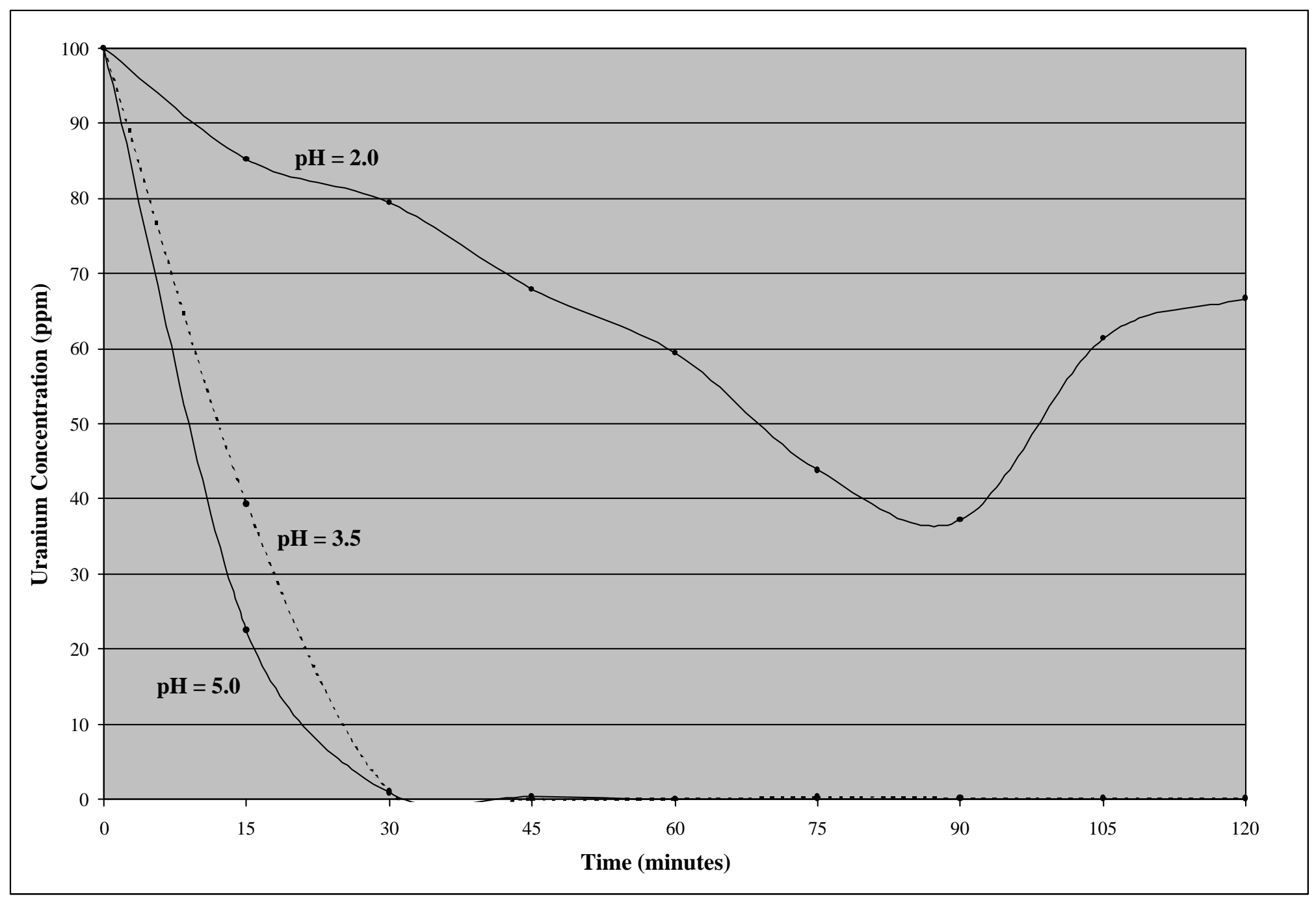

Figure 5 - 19. Effect of pH Variation on Fiber Performance 
It should be noted that an attempt to test the performance at a $\mathrm{pH}$ of 7.0 resulted in the precipitation of a uranium solid, making the experiment impossible to complete. Because of the presence of the solid, very high removal efficiencies were noted in the presence of a positive current, indicating that the solid was most likely being filtered by the fiber.

\subsection{Effect of Cyclic Loading/Stripping of Fibers}

Following the completion of the abovementioned experiments, the baseline fiber (PR-1-ox400) was repeatedly loaded (not to full capacity) with uranium and stripped, then reloaded etc. according to the procedure outlined in Chapter 4. The process was repeated six times to determine the effect on the removal efficiency of the fibers. The results of the experiment are shown in Figure 5-20.

As expected, the initial run looks nearly identical to the performance run for these same fibers. However, what is unexpected is that as opposed to the fibers becoming less effective following subsequent runs, the fibers actually become slightly more effective. This is most likely due to some residual uranium precipitate on the surface of the carbon that results in a more rapid removal rate in the initial stages of electrosorption. It should be noted again that the carbon was not exhausted prior to regeneration but just taken to some arbitrary level of uranium content, here approximately 45 minutes.

\subsection{Fiber Capacity}

The final experiment used to evaluate the fiber performance was one designed to determine the capacity of the fiber for uranium electrosorption. Again, the baseline fiber was used (PR-1-ox400) and the same amount was used as that in the performance experiments, $0.2 \mathrm{~g}$. The concentration of the feed was increased to $1,000 \mathrm{ppm}$ and the flow rate and $\mathrm{pH}$ of the solution were maintained at $0.7 \mathrm{~mL} / \mathrm{min}$ and 3.5 , respectively. The experiment involved allowing the cell to run for several days while maintaining the influent conditions. Samples were taken several times daily to monitor performance. The effluent concentration initially decreased to between 200 and $225 \mathrm{ppm}$ and maintained this steady-state concentration for approximately 12 hours. After 12 hours, the effluent concentration began to increase. Finally, after 40 hours, it became obvious that the fibers were exhausted and the experiment was halted. After completing a mass 


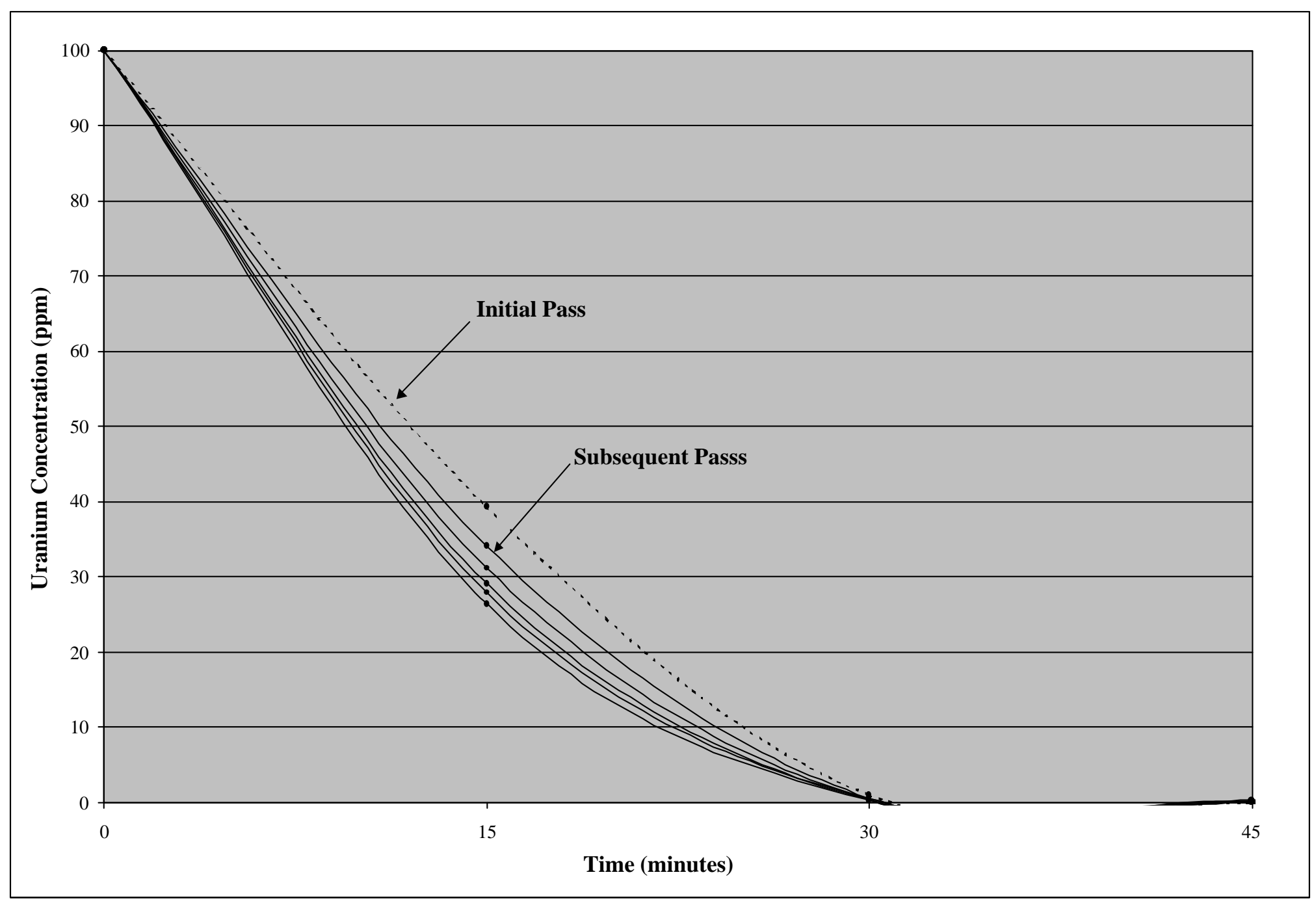

Figure 5 - 20. Effect of Cyclic Loading/Stripping on Fiber Performance 
balance, it was determined that a loading of $5.45 \mathrm{~g}_{\text {uranium }} / \mathrm{g}_{\text {fiber }}$ was achieved over the 40 hour period. A plot of the effluent concentration as a function of time is shown in Figure $5-21$.

It should be noted that the mass balance was performed by collecting the effluent from the cell for the entire duration of the experiment in $500-\mathrm{mL}$ increments. The concentration of the collected effluent was then determined. Because the influent concentration was known, once the effluent concentration was determined, the amount of uranium deposited on the carbon could be determined for that $500-\mathrm{mL}$ increment.

A final point worth noting in relation to this experiment is the fact that as the uranium deposits within the cell, it decreases the working volume inside the cell and thereby increases the local flow rate, in effect, increasing the fluid velocity and decreasing the residence time. The diminishing capacity demonstrated in the later stages of this experiment could be due to an increase in flow rate that has already been shown to reduce the fibers' capacity (see Section 5.3). Future experiments involving scaled-up models will be better apt at addressing this issue.

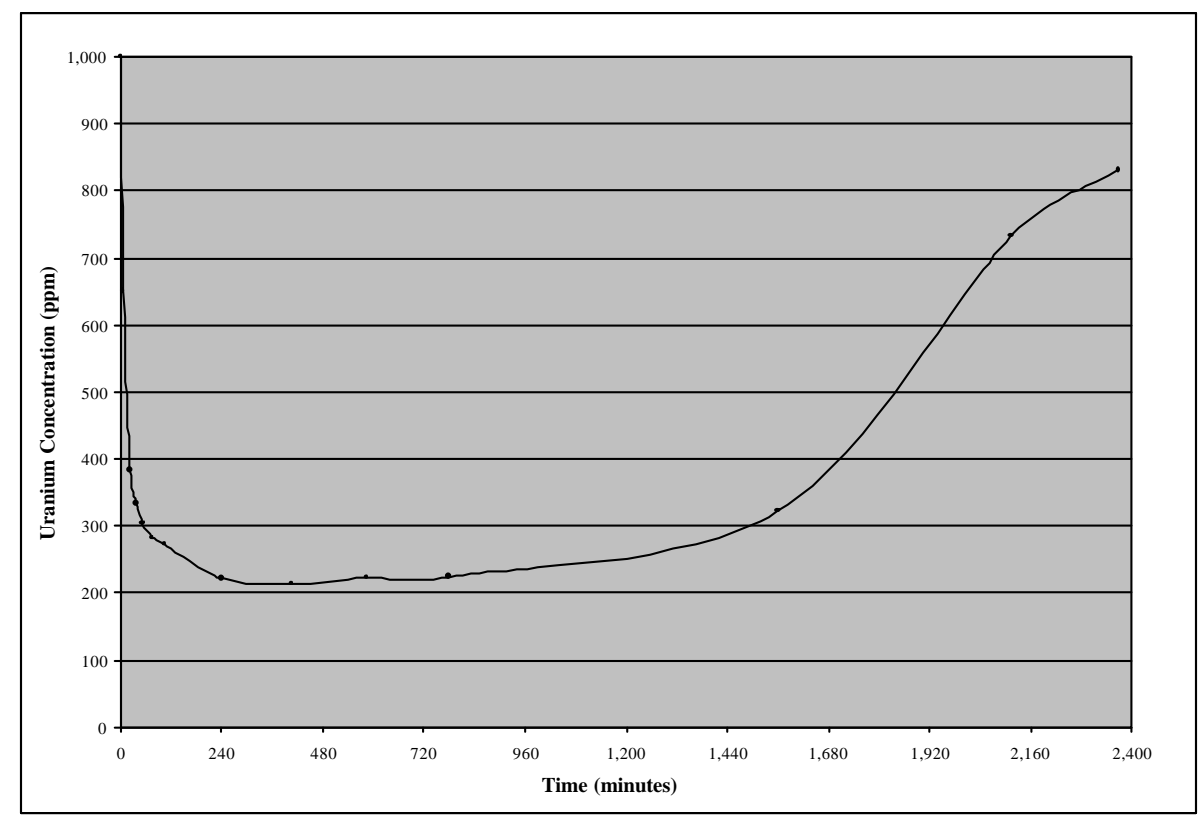

Figure 5 - 21. Evaluation of Fiber Capacity 


\subsection{Possible Effect of Residual Iron}

Because the fibers are produced using an iron catalyst, it was thought that possible residual iron present in the fibers might have been contributing to the effectiveness of the uranium removal process by acting as a magnet. Therefore, it was of interest to determine the amount of iron present in the ten fiber samples. Ash tests were performed by heating $0.5 \mathrm{-g}$ samples of fiber to $750^{\circ} \mathrm{C}$ in air and maintaining this temperature for at least four hours. This process burns off all carbon and leaves only the oxides of the metals in the original fiber. Several of the fibers were determined to contain significant amounts of residual ash. Although it is possible that other metal oxides are present, it is likely that the majority of the ash is composed of iron oxide as it is known that the fibers are fabricated using an iron catalyst and the ash residue appeared to be rust colored upon visual inspection. No other metals should be present since none were added initially. The carbon feed, whether $\mathrm{CH}_{4}$ or methane, were pure gases. The results of the ash tests are shown in Figure 5-22.

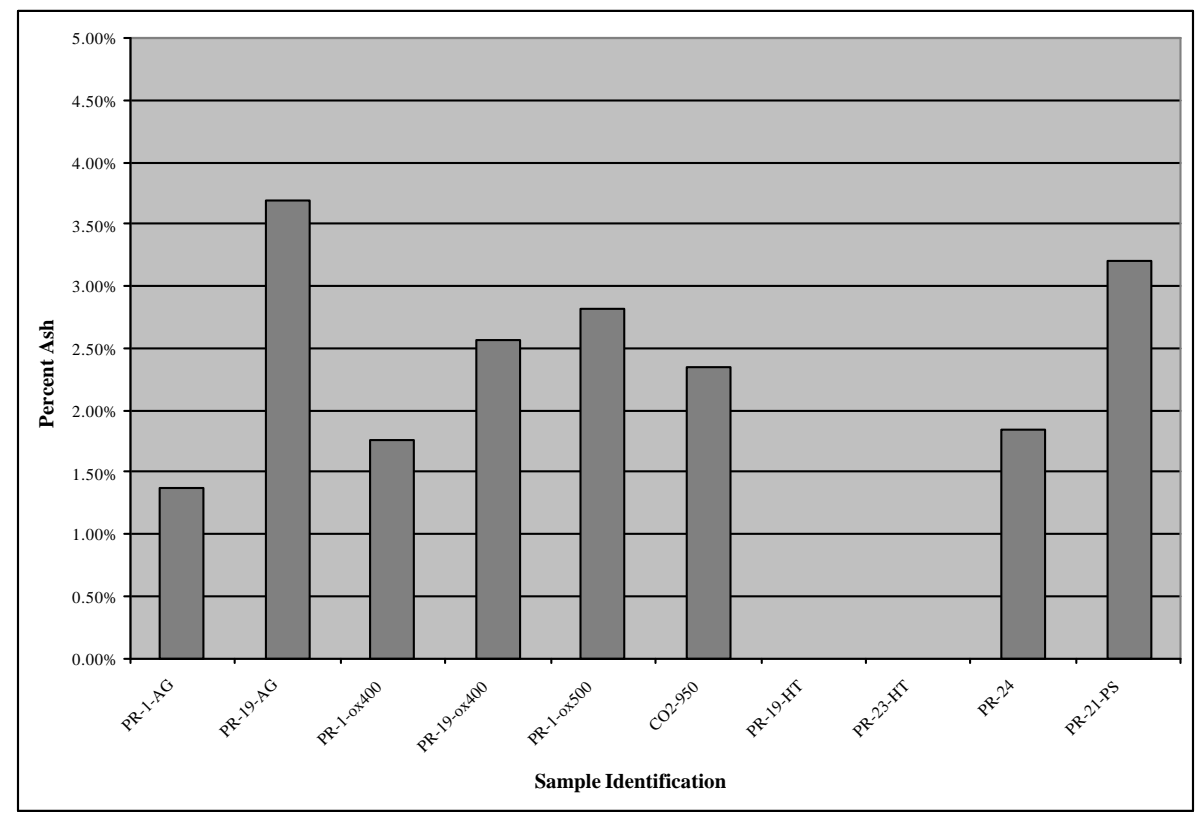

Figure 5 - 22. Percent Residual Ash in Fiber Samples

Although all samples contained significant amounts of ash, the fibers produced from natural gas had a higher ash content on average than the other fibers. The reason for 
this is unknown; perhaps the carbon layer is thinner and results in a higher iron concentration by weight or perhaps a higher concentration of catalyst was employed. Despite the high ash content in the majority of the samples, the two heat-treated graphitized fiber samples, PR-19-HT and PR-23-HT, contained no residuals. This is due to the volatilization of the iron at the high temperatures used to treat the fibers (i.e., over $\left.3,000^{\circ} \mathrm{C}\right)$. Because all the fibers were effective in uranium removal and two fibers contained no residuals, it can be concluded that the presence of iron does not contribute to the effectiveness of the fibers.

\subsection{Attempt to Identify Surface Functional Groups Using FT-IR Analysis}

As stated in the scope of research, because the surface functional groups are believed to contribute to the effectiveness of the fibers, it is desirable to identify any groups present. Several attempts to obtain information about the fibers were made. Pellets used to conduct the FT-IR analysis were prepared using varying amounts of fiber and potassium bromide $(\mathrm{KBr})$. Potassium bromide is used because it does not interfere with the spectra, as it does not produce bands above $400 \mathrm{~cm}^{-1}$, which is the region of interest [61]. Despite vigorous efforts and attempts with varying ratios of fiber to $\mathrm{KBr}$, a distinctive analysis was unable to be obtained.

Following the problems encountered during the analysis attempts, a brief literature search was conducted to determine the feasibility of using FT-IR analysis to identify functional groups. It has been firmly established that analysis of carbon fibers using FT-IR techniques results in difficulties due to the strong absorbance and scattering of infrared radiation by the carbon fibers [62]. In recent years, XPS has been the technique of choice for analysis of carbon fibers since the fibers do not interfere with data

collection; this technique provides nearest-neighbor information, which would be desirable. It has also been determined that FT-IR analysis can be used to analyze carbon fibers but only after careful optimization of the conditions, an effort that was beyond the scope of this study. Therefore, analysis of the fibers using FT-IR techniques was abandoned. 


\subsection{Identification of Uranium Solid By X-Ray Diffraction}

The solid obtained upon stripping the fibers was collected and analyzed via x-ray diffraction techniques. The solid was air dried at room temperature prior to analysis. The results showing the various diffraction peaks can be seen in Figure 5-23. The results were somewhat inconclusive and indicated that the solid contained a barium atom, a substance that is not present anywhere in the system. It is likely that the actual uraniumbearing solid was not present within the database with which the spectrum was compared. Regardless, the analysis indicates that the solid stripped from the carbon fibers is some type of complex uranium hydroxide hydrate (i.e., $\mathrm{X}\left(\mathrm{UO}_{2}\right)_{6} \mathrm{O}_{4}(\mathrm{OH})_{6} \cdot 8\left(\mathrm{H}_{2} \mathrm{O}\right)$ ).

\subsection{Examination of Fibers Using SEM}

Finally, two of the fiber samples were analyzed using a scanning electron microscope (SEM). The purpose of the test was to identify the edge planes present on the surfaces of the fibers and to discern any surface difference between the "as-grown" fibers and the fibers that underwent post-treatment techniques. Two fibers were chosen, PR-1AG and PR-19-HT.

Upon inspection of the SEM photographs of the fibers at a magnification of 25,000X, no drastic or significant differences were noticed. It was also impossible to discern the edge planes at this level of magnification. It is however possible to distinguish that the surface of the as grown (PR-1-AG) fibers tends to have a smoother texture than the heat-treated (PR-19-HT) fibers. This is most likely due to the removal of surface material that is vaporized during the post-treatment process. The SEM photographs of PR-1-AG and PR-19-HT are shown below as Figures 5-24 and 5-25, respectively. However, on the whole, no significant differences were noted between the two surfaces of the fiber samples. 


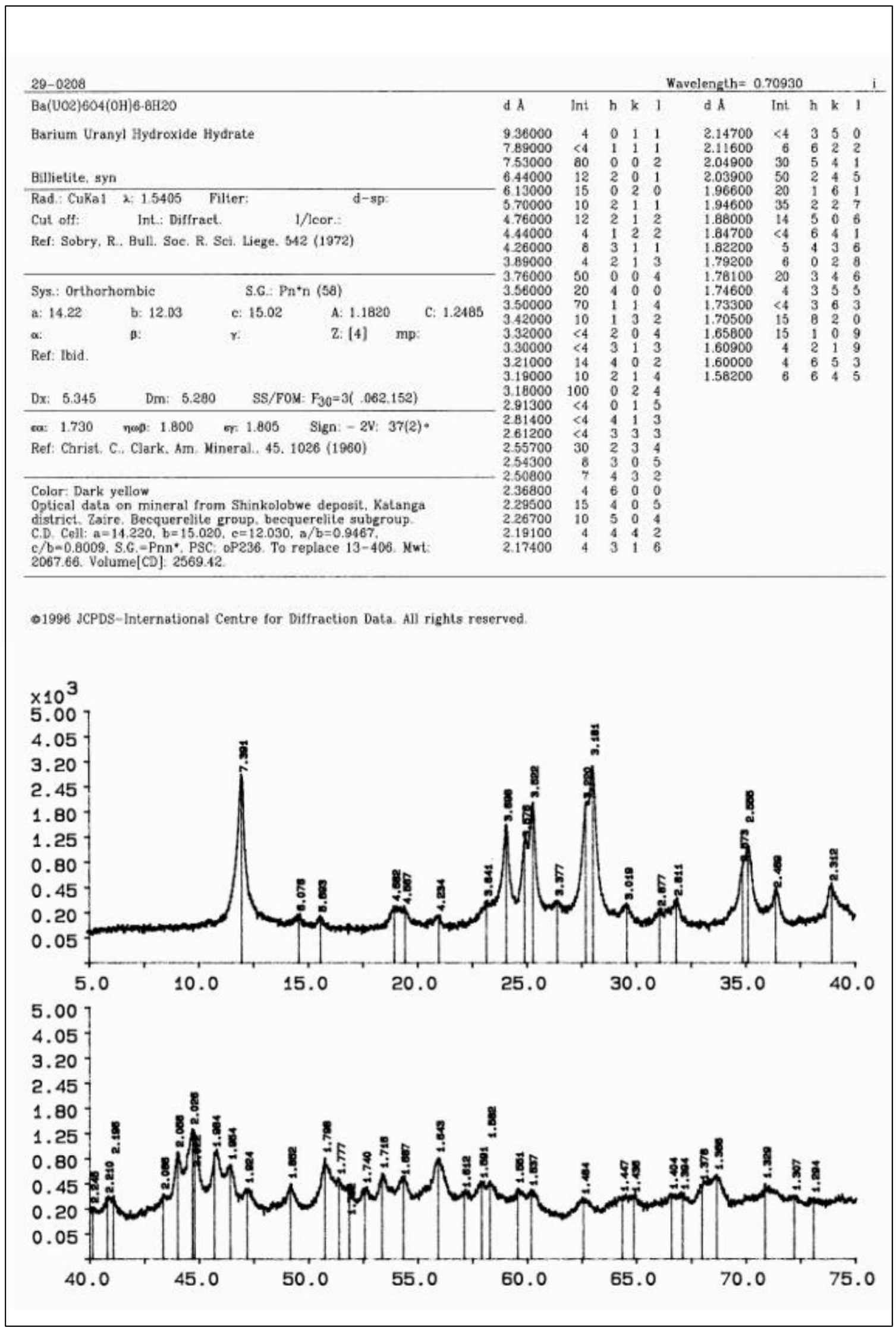

Figure 5 - 23. Results of X-Ray Diffraction Analysis 


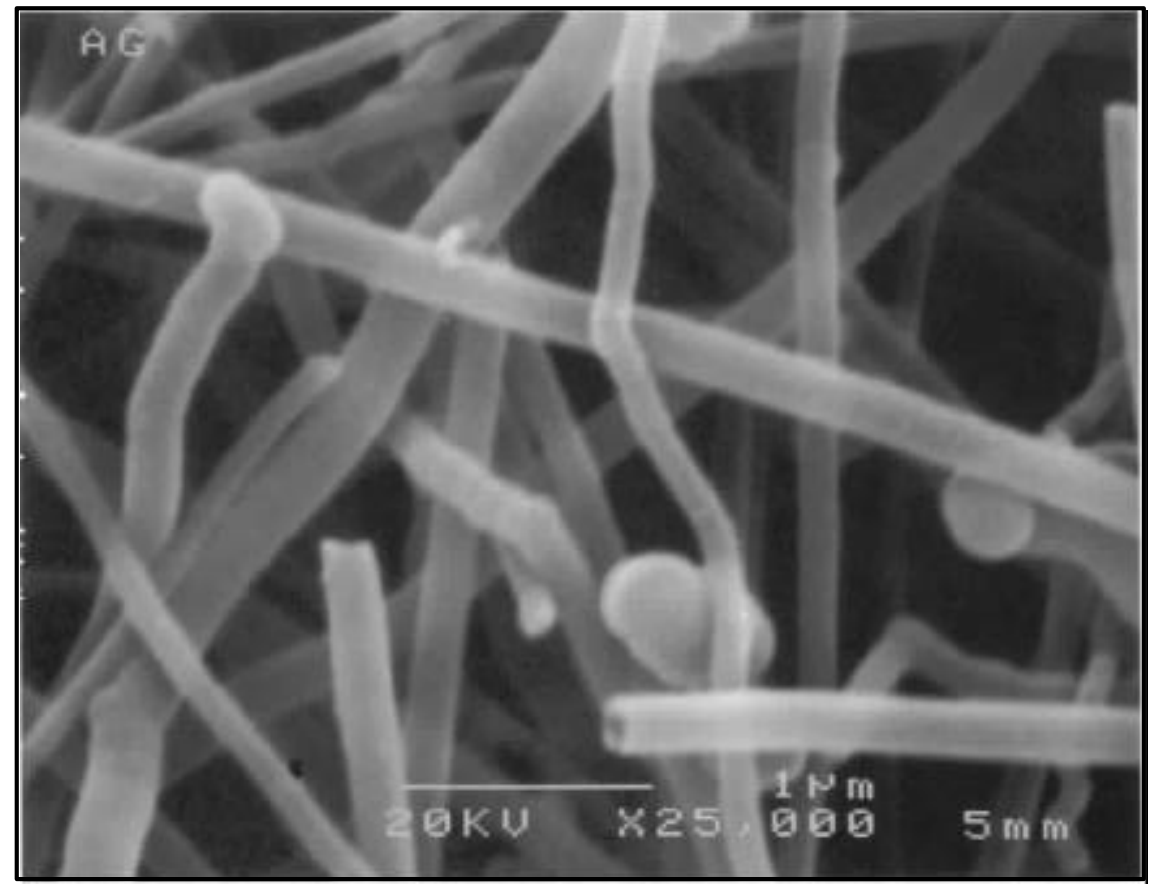

Figure 5 - 24. SEM of PR-1-AG Showing Smooth Surface

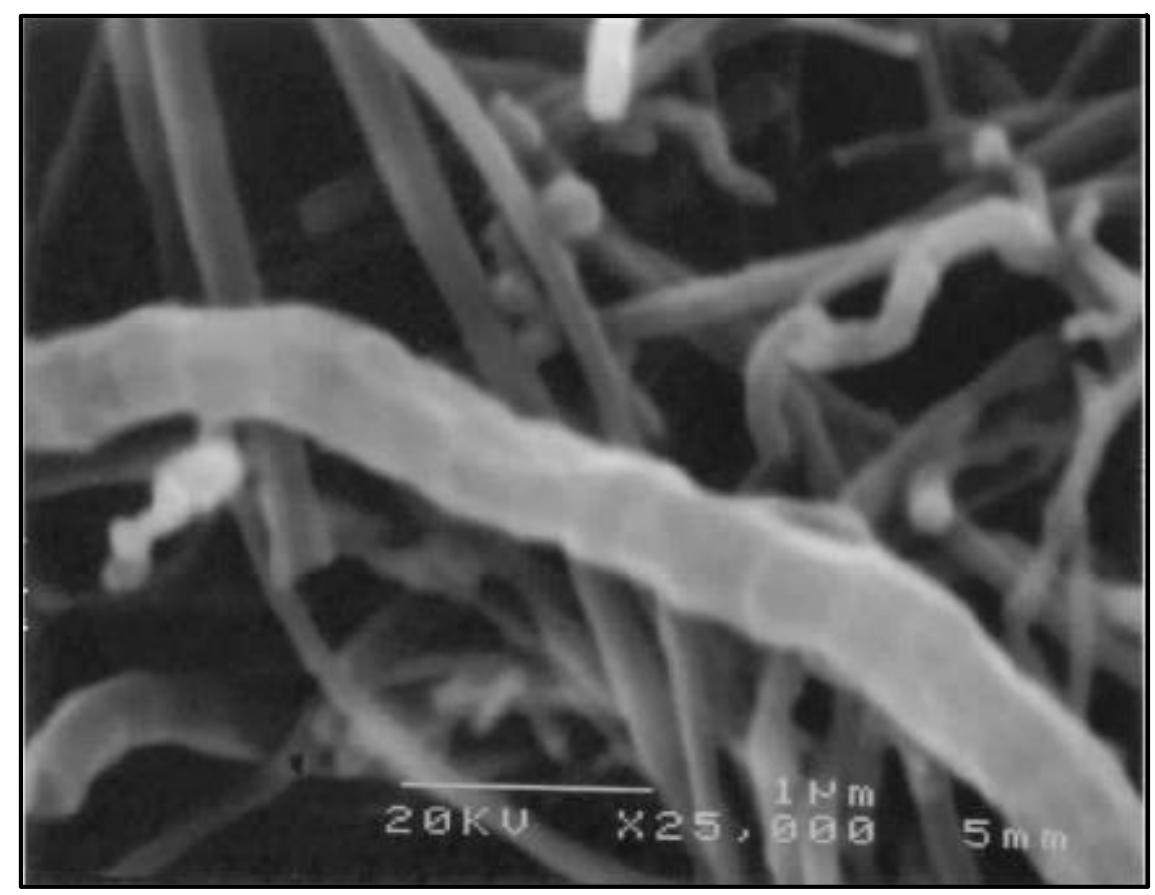

Figure 5 - 25. SEM of PR-19-HT Showing Surface Roughness Following Post-Treatment 


\section{CHAPTER 6}

\section{CONCLUSIONS AND RECOMMENDTIONS}

The purpose of this study was to determine the effect of varying the surface properties of catalytically grown carbon nanofibers on uranium removal. The fibers were subjected to performance experiments that were used to compare them. Following these initial experiments, the experimental parameters including cell potential, flow rate, and $\mathrm{pH}$ of influent were varied to determine their effect on the uranium removal phenomenon. A final set of experiments was conducted to determine the effect of repeatedly loading and stripping the fibers on removal efficiency and the capacity of the fibers for electrosorption. Attempts were made to identify surface functional groups and to determine the identity of the uranium solid obtained upon stripping the fibers.

\subsection{Performance Experiments}

The ten fibers were tested using a feed of $100 \mathrm{ppm}$ at a flow rate of $0.7 \mathrm{~mL} / \mathrm{min}$ and a $\mathrm{pH}$ of 3.5. All fibers were successful in removing uranium to below $1 \mathrm{ppm}$. Although significant differences were introduced with the various fibers, the alterations in fiber characteristics did not affect fiber performance. It is therefore obvious that the property specific to the ASI carbon nanofibers that results in these high removal efficiencies has yet to be identified. Although it was previously believed that the surface functional groups were responsible for the effectiveness of the fibers, this study indicates that the concentration of these functional groups is not the controlling parameter of the fiber performance.

\subsection{Variation of Parameters}

Three experimental parameters were varied to test their effects on the uranium removal efficiency including cell potential, flow rate, and $\mathrm{pH}$. The cell potential was varied from zero (pure adsorption) to $-0.9 \mathrm{~V}$, the potential used to conduct the performance experiments. Little removal was realized at zero, $-0.1 \mathrm{~V}$, or $-0.2 \mathrm{~V}$. Upon

applying a potential of $-0.3 \mathrm{~V}$, some removal was noted; however, the steady-state concentration remained at between 85 and $95 \mathrm{ppm}$. It was not until the cell potential 
reached $-0.4 \mathrm{~V}$ that the uranium removal significantly increased, maintaining a steadystate effluent concentration of approximately $15 \mathrm{ppm}$. It is likely that there is a limiting applied potential at which the precipitation mechanism is initiated. Further increases in potential including $-0.5 \mathrm{~V},-0.7 \mathrm{~V}$, and $-0.9 \mathrm{~V}$ resulted in maintaining an effluent concentration of below $1 \mathrm{ppm}$. Therefore, the limiting applied potential is reached somewhere between -0.4 and $-0.5 \mathrm{~V}$.

The second parameter, the flow rate, affected the uranium removal rate significantly. It was determined that the flow rate could be set to twice that of the initial flow rate, resulting in a feed of $1.4 \mathrm{~mL} / \mathrm{min}$ and still maintain an effluent concentration of below 1 ppm uranium. However, upon tripling the flow rate, the effluent concentration increased to between 15 and $20 \mathrm{ppm}$. Operating the cell at a flow rate two and a half times the original flow rate resulted in a steady-state effluent concentration of $5 \mathrm{ppm}$. It was therefore determined that the limiting flow rate is located somewhere between 1.4 and $1.8 \mathrm{~mL} / \mathrm{min}, 1.5 \mathrm{~mL} / \mathrm{min}$ approximately.

The final test parameter was $\mathrm{pH}$. A range of $\mathrm{pHs}$ was considered including 2.0, 3.5 (used in the performance experiments), 5.0, and 7.0. Decreasing the $\mathrm{pH}$ to 2.0 resulted in decreased removal efficiency and is therefore not desirable. Increasing the $\mathrm{pH}$ from 3.5 to 5.0 achieved the same high removal efficiency. The final increase in $\mathrm{pH}$ from 5.0 to 7.0 resulted in the formation of a uranium precipitate that was filtered by the fiber even when a positive potential was applied and therefore the experiment could not be completed. It appears from this information that the technique is not effective at $\mathrm{pHs}$ at or below 2.0. Because no pHs were tested between 2.0 and 3.5, the limiting $\mathrm{pH}$ was not clearly determined. It appears that increases in $\mathrm{pH}$, increase the removal efficiency of the process until precipitation is achieved at which point the uranium can simply be filtered and removed.

\subsection{Removal Efficiency and Fiber Capacity}

The baseline fiber (PR-1-ox400) was loaded-stripped and reloaded several times to determine the effect of cycling on the removal efficiency. It was found from the experiment that the fibers' efficiency is not only maintained throughout the cycles, but is actually improved by prior loading with uranium. This is most likely due to residual 
uranium precipitates that are not expelled from the fiber surface during stripping. These precipitates then provide sites for more immediate precipitation of additional uranium, resulting in quicker removal during subsequent loadings.

The fiber capacity was also determined through an extensive loading experiment involving a run that lasted for several days. The feed concentration was increased to $1,000 \mathrm{ppm}$ to speed up the saturation process. The flow rate and $\mathrm{pH}$ were maintained at $0.7 \mathrm{~mL} / \mathrm{min}$ and 3.5, respectively. The cell broke through after approximately 15 hours when the fibers apparently became saturated with uranium. Breakthrough lasted for several hours and the experiment was halted after 40 hours. The capacity was determined to be $5.45 \mathrm{~g}_{\text {uranium }} / \mathrm{g}_{\text {fiber }}$ for the entire 40 -hour period.

It should be noted that it is not clear whether the loading of the fiber is a function of nucleation sites. Deposition of the uranium throughout the process of the experiment causes a decrease in the working free volume of the cell. Therefore, as more uranium is deposited, it causes an increase in the local flow rate and could therefore result in an

apparent decrease in removal efficiency. In addition to being affected by these conditions, the capacity is also expected to be fiber specific although this was not studied here.

\subsection{FT-IR, X-Ray Diffraction Analysis, and SEM}

An attempt was made to characterize the surface functional groups of the carbon fibers using FTIR analysis. The attempt was unsuccessful however due to the strong absorbance and scattering of infrared radiation by the thick carbon fibers. It was therefore not possible to correlate fiber performance with surface functional groups although several of the fiber samples were assumed to have decreased surface functionality and performed as well as other fibers with increased surface functionality.

Attempts to identify the solid uranium precipitate were inconclusive. The solid was dried at room temperature and analyzed via $\mathrm{x}$-ray diffraction. The analysis resulted in predicting the presence of a barium atom that is not present in the system. It is highly likely that an exact match was not present in the XRD database. The form of the solid however indicates a complex uranium hydroxide hydrate. 
Two fiber samples were analyzed using SEM techniques in an attempt to identify edge plane density and other surface characteristics; however, the edge planes were not apparent at the magnification used $(25,000 \mathrm{X})$. There was a minor difference between the surface of the fibers in that the "as-grown" fibers appeared to be significantly smoother than the heat-treated fibers. This is believed to be due to the pyrolytic materials that are stripped from the surface of the heat-treated fibers during post-treatment.

\subsection{Recommendations for Future Work}

Unfortunately, several of the results presented herein are inconclusive and do not provide a strong insight into the uranium removal mechanism. It is still unclear exactly which fiber characteristics make it effective in the removal process. It is however obvious that the surface functional groups or the presence of iron are not significant concerns. Conducting the performance experiments at a higher feed concentration or flow rate could provide additional insight into which fibers are extremely effective while others remain moderately effective. It is not clear that the full potential of all the fibers was realized during these experiments.

A more thorough investigation of uranium chemistry and the relationship between chemical reactions involving uranium and the potentials at which they occur could provide a significant piece to the puzzle of determining the removal mechanism. It remains unclear whether the removal is the result of one reaction or more than one occurring in series.

Finally, a more detailed study of the experimental parameters involving potential, flow rate, and $\mathrm{pH}$ could more accurately identify the key conditions that contribute to making this technique effective. More detail concerning limiting potential and $\mathrm{pH}$ could provide valuable information regarding the removal mechanism while the limiting flow rate would provide insight into the electrosorption rate and the possibility of scale-up.

The work presented herein confirms the findings established in previous studies that this technique can be used to treat aqueous wastes effectively and efficiently and obtain uranium in a solid form as opposed to a concentrated aqueous solution. This would allow the uranium to be disposed of as a solid without the need for additional posttreatments. 


\section{REFERENCES}

1. Hatfield, T.L., T.L. Kleven and D.T. Pierce, Journal of Applied Electrochemistry, 26, 1996, p. 567-574.

2. Rao C.S., Environmental Pollution Control Engineering, Wiley, 1991.

3. Kinoshita, K., Carbon: Electrochemical and Physiochemical Properties, Wiley, New York, NY, 1998.

4. Xu, Y., "Electrochemical Treatment of Metal-bearing Aqueous Wastes Based on Novel Forms of Carbon", Ph.D. Dissertation, Dept. of Chemical Engg., West Virginia University, 1999.

5. U.S. E.P.A., "National Primary Drinking Water Regulations: Radionuclides: Advanced Notice of Proposed Rulemaking", Federal Register, 56:138 (40) CFR Parts 141 and 142, 1991.

6. Lee, S.Y. and E.A. Bondietti, "Removing Uranium from Drinking Water by Metal Hydroxides and Anion-exchange Resins", J. AWWA, 75(10):536, 1983.

7. Hanson, S.W., D.B. Wilson, N.N. Gunaji and S.W. Hathaway, "Removal of Uranium from Drinking Water by Ion-exchange and Chemical Clarification", EPA/600/S2-87/076, Dec. 1986.

8. Huxstep, M.R. and T.J. Sorg, "Reverse Osmosis Treatment to Remove Inorganic Contaminants from Drinking Water", US EPA Report/600/52-87/109, March 1987.

9. Clifford, D.A. and Z. Zhang, Removing Uranium and Radium from Groundwater by Ion Exchange Resins, Ed. A.K. Sengupta, Ion Exchange Technology, Technomic, Lancaster, PA, 1995.

10. Hathaway, S.W., Uranium Removal Processes, In Pros. AWWA Ann. Conference, Las Vegas, NV, 1983.

11. Lassovszky, P. and S.W. Hathaway, "Treatment Technologies to Remove Radionuclides from Drinking Water", Paper Presented at the National Workshop on Radioactivity in Drinking Water of the US Environmental Protection Agency, Office of Drinking Water, May 23-26, 1983.

12. Sorg, T.J., "Methods for Removing Uranium from Drinking Water", J. AWWA, 80(7):105, 1988. 
13. Lee, S.Y., S.K. Hall and E.A. Bondetti, "Methods of Removing Uranium from Drinking Water: II, Present Municipal Water Treatment and Potential Removal Methods", EPA 570/9-82-003, Washington, DC, 1982.

14. Hathaway, S.W., "Current Research on Uranium Removal from Drinking Water", US EPA Small Water Systems Technology Seminar, April 1982.

15. Udal'tsova N.I., Chemico-Analytical Properties of Uranium and Its Compounds in Analytical Chemistry of Uranium, Ed. P.N. Palei, Ann Arbor, London, GB, 1970.

16. Farmer J.C., S.M. Bahowick, J.E. Harar, D.V. Fix, R.E. Martinelli, A.K. Au, and K.L. Carroll, Energy and Fuels, 11, 1997, p. 337-347.

17. Frackowiak, E., Fuel, 77, No. 6, 1998, p. 571-575.

18. Grebenyuk, V.D., N.A. Linkov and V.M. Linkov, Water SA, 24, No. 2, 1998, p. 123-127.

19. Hazourlis S., G. Bonnecaze and M. Astruc, Environmental Technology, 17, No. 12, 1996, p. 1275-1283.

20. Hazourlis S., G. Bonnecaze and M. Astruc, Environmental Technology, 17, No. 12, 1996, p. 1285-1295.

21. Hazourlis S., G. Bonnecaze and M. Astruc, Environmental Technology, 17, No. 12, 1996, p. 1297-1312.

22. Godeltisas, A., P. Misaelides, A. Filippidis, D. Charistos and I. Anousis, J. Radioanalytical and Chemistry, 208, No. 2, 1996, p. 393-402.

23. Guler, H., N. Sahiner, G.A. Aycik and O. Guven, Journal of Applied Polymer Science, 66, No. 3, 1997, p. 2475-2480.

24. Benes, P., K. Kratzer, S. Vlckova and E. Sebestova, Chemicke Listy, 91, No. 9, 1997, p. 774-775.

25. Sato, T., T. Murakamit, N. Yanase, H. Isobe, T.E. Payne and P.L. Airey, Environmental Science and Technology, 31, No. 10, 1997, p. 2854-2858.

26. Kaplan, D.I., T.L. Gervais and K.M. Krupka, Radiochimica Acta, 80, No. 4, 1998, p. 201-211.

27. Wei, Y.Z., M. Kumagai, Y. Takashima, M. Asou, T. Namba, K. Suzuki, A. Maekawa and S. Ohe, Journal of Nuclear Science and Technology, 35, No. 5, 1998, p. 357-364. 
28. Zhang, X.Z., S.G. Luo, Q. Yang, H.L. Zhang and J.Y. Li, Journal of Applied Phycology, 9, No. 1, 1997, p. 65-71.

29. Tsezos, M., Z. Georgous and E. Remoudakie, Journal of Chemical Technology and Biotechnology, 70, No. 2, 1997, p. 198-206.

30. Roig, M., G. Manzano and M. Diaz, Water Research, 31, No. 8, 1997, p. 20732083.

31. Riordan, C., M. Bustard, R. Putt, A.P. Michale, Biotechnology Letters, 19, No. 4, 1997, p. 385-387.

32. Hu, M.Z.C. and M. Reeves, Biotechnology Progress, 13, No. 1, 1997, p. 60-70.

33. Lovely, D.R., E.J.P. Philips, Y.A. Gorby and E.R. Landa, Nature, 350, April 1991, p. 413.

34. Lovely, D.R. and E.J.P Philips, Applied and Environmental Microbiology, Mar. 1992, p. 850-856.

35. Truex, M.J., B. Peyton, N.B. Valentine and Y.A. Gorby, Biotechnology and Bioengineering, 55, No. 3, August 5, 1997, p. 490-496.

36. Katz, J. and E. Rabinowitch. The Chemistry of Uranium, Nila, Wiley, 1951.

37. Katz J. and G.T. Seaborg, The Chemistry of Actinide Elements, 1957.

38. Akimov, G.V. and I.L. Rosenfeld, In: Issledovaniya $v$ oblasti elektrokhimicheskogo i korrozionnogo povedeniya metallov i splavov, Moscow, Oborongiz, 1950.

39. Seaborg, G.T. and J. Katz, The Actinide Elements, New York, McGraw-Hill, 1954.

40. Hietanen, S. and Z. Sillen, Acta chim. Scand., 8, 1607, p. 1954.

41. Kraus, K.A. and F. Nelson, J. Am. Chem. Soc., 77, 1955, p. 3721.

42. Tyurikov, G.S., K.I. Rosental and V.I. Veselovskii, ZhFKh, 32, 1490, 1958.

43. Rao, G.G., V.P. Rao and N. Venkatamma, -Z. anal. Chem., 150, 178, 1956.

44. Rao, V. and G. Rao, -Z. anal. Chem., 160, 190, 1958.

45. Rao, G.G. and V.P. Rao, Anal. Chim. Acta., 15, 97, 1956. 
46. Grenberg, A.A., G.I. Petrazhak, L.E. Nikol'Skaya, B.V. Pittsyn and F.M. Filinov, Trudy Radievogo Instituta AN SSSR, 8, 166, 1958.

47. Ushatskii, V.N. and Y.M. Tolmachev, Trudy Radievogo Instituta AN SSSR, 7, 8, 1956.

48. Ratner, A.P. and P.I. Chaikin, Sbornik rabot po radiokimii, Moscow, Izd. LGU, 1955.

49. Kern, D.M.H. and E.F. Orleman, J. Am. Chem. Soc., 71, 2102, 1949.

50. Nelson, F. and K.A. Kraus, J. Am. Chem. Soc., 73, 2157, p. 1951.

51. MacKay, H.A.C., Trans. Farady Soc., 47, 1951, p. 436.

52. Brusilovskii, S., A., Doklady AN SSSR, 120, 1958, p. 305.

53. Lipilina, I.I., Doklady AN SSSR, 122, 1958, p. 238.

54. Ahrland, S., Acta Chim. Scand., 3, 374, 1949.

55. Komar, N.P. and Z.A. Tret'yak, ZhAKh, 10, 236, 1955.

56. Sutton, J., J. Chem. Soc., Suppl. Iss., p. 275, 1949.

57. Hearnen, J. and A. White, J. Chem. Soc., 1957, p. 2168.

58. Pourbaix, M., Atlas of Electrochemical Equilibria in Aqueous Solutions, Pergamon Press, New York, 1966.

59. Skoog, D.A. and J.L. Leary, Principles of Instrumental Analysis, $4^{\text {th }}$ Ed., Saunders College Publishing, New York, 1992.

60. Brennsteiner, A., J. Zondlo, A.H. Stiller, P.G. Stansberry, D. Tian and Y. Xu, Energy and Fuels, 11, 1997, p. 348-353.

61. Pavia, D.L., G.M. Lampman and G.S. Kriz, Introduction to Spectroscopy, $2^{\text {nd }}$ Ed., Saunders College Printing, New York, 1996.

62. Ohwaki, T. and H. Ishida, Applied Spectroscopy, 39, 3, 1995, p. 341-348. 
APPENDIX 


\section{PERFORMANCE EXPERIMENTS}

\section{PR-1-0x400}

\begin{tabular}{|r|r|r|r||}
\hline \multicolumn{4}{|c|}{ Initial Run (7/6/00) } \\
\hline \hline $\begin{array}{c}\text { Time } \\
\text { (min.) }\end{array}$ & $\begin{array}{c}\text { Ave. Time } \\
\text { (min.) }\end{array}$ & $\begin{array}{c}\text { Peak Ht. } \\
\text { (:A) }\end{array}$ & $\begin{array}{c}\text { Conc. } \\
\text { (ppm) }\end{array}$ \\
\hline 0 & 0.0 & NA & 100.00 \\
\hline 13 & 6.5 & $-1,007.40$ & 39.29 \\
\hline 25 & 19.0 & -26.24 & 1.02 \\
\hline 37 & 31.0 & -1.51 & 0.06 \\
\hline 48 & 42.5 & -1.48 & 0.06 \\
\hline 59 & 53.5 & -8.12 & 0.32 \\
\hline 73 & 66.0 & -4.45 & 0.17 \\
\hline 87 & 80.0 & -2.65 & 0.10 \\
\hline 101 & 94.0 & -2.19 & 0.09 \\
\hline 117 & 109.0 & -6.17 & 0.24 \\
\hline 131 & 124.0 & -4.29 & 0.17 \\
\hline 160 & 145.5 & -0.96 & 0.04 \\
\hline 175 & 167.5 & ND & $<0.05$ \\
\hline 480 & 480.0 & ND & $<0.05$ \\
\hline
\end{tabular}

\begin{tabular}{|r|r|r|r||}
\hline \multicolumn{4}{|c|}{ Subsequent Run (8/16/00) } \\
\hline \hline $\begin{array}{c}\text { Time } \\
\text { (min.) }\end{array}$ & $\begin{array}{c}\text { Ave. Time } \\
\text { (min.) }\end{array}$ & $\begin{array}{c}\text { Peak Ht. } \\
\text { (:A) }\end{array}$ & $\begin{array}{c}\text { Conc. } \\
\text { (ppm) }\end{array}$ \\
\hline \hline 0 & 0.0 & NA & 100.00 \\
\hline 15 & 6.5 & -892.80 & 34.82 \\
\hline 30 & 22.5 & -57.81 & 2.25 \\
\hline 45 & 37.5 & -13.48 & 0.53 \\
\hline 60 & 52.5 & -2.04 & 0.08 \\
\hline 75 & 67.5 & -5.16 & 0.20 \\
\hline 90 & 82.5 & -1.26 & 0.05 \\
\hline 105 & 97.5 & -2.16 & 0.08 \\
\hline 120 & 112.5 & ND & $<0.05$ \\
\hline 420 & NA & ND & $<0.05$ \\
\hline 480 & NA & ND & $<0.05$ \\
\hline
\end{tabular}

\section{PR-1-0x500}

\begin{tabular}{|r|r|r|r||}
\hline \multicolumn{5}{|c||}{ Initial Run (7/11/00) } \\
\hline \hline $\begin{array}{c}\text { Time } \\
\text { (min.) }\end{array}$ & $\begin{array}{c}\text { Ave. Time } \\
\text { (min.) }\end{array}$ & $\begin{array}{c}\text { Peak Ht. } \\
(: A)\end{array}$ & $\begin{array}{c}\text { Conc. } \\
\text { (ppm) }\end{array}$ \\
\hline \hline 0 & 0.0 & NA & 100.00 \\
\hline 15 & 7.5 & -690.30 & 26.93 \\
\hline 30 & 22.5 & -21.60 & 0.84 \\
\hline 45 & 37.5 & -7.93 & 0.31 \\
\hline 60 & 52.5 & ND & $<0.05$ \\
\hline 75 & 67.5 & -2.36 & 0.09 \\
\hline 90 & 82.5 & -3.01 & 0.12 \\
\hline 105 & 97.5 & ND & $<0.05$ \\
\hline 135 & 120.0 & -6.04 & 0.24 \\
\hline 195 & NA & -2.58 & 0.10 \\
\hline 300 & NA & ND & $<0.05$ \\
\hline 480 & NA & ND & $<0.05$ \\
\hline \hline
\end{tabular}

\begin{tabular}{|r|r|r|r||}
\hline \multicolumn{4}{|c|}{ Subsequent Run (9/14/00) } \\
\hline \hline $\begin{array}{c}\text { Time } \\
\text { (min.) }\end{array}$ & $\begin{array}{c}\text { Ave. Time } \\
\text { (min.) }\end{array}$ & $\begin{array}{c}\text { Peak Ht. } \\
(: \mathbf{)})\end{array}$ & $\begin{array}{c}\text { Conc. } \\
\text { (ppm) }\end{array}$ \\
\hline \hline 0 & 0.0 & NA & 100.00 \\
\hline 15 & 7.5 & -475.80 & 18.56 \\
\hline 30 & 22.5 & -22.13 & 0.86 \\
\hline 45 & 37.5 & -5.75 & 0.22 \\
\hline 60 & 52.5 & -15.96 & 0.62 \\
\hline 75 & 67.5 & -2.18 & 0.09 \\
\hline 90 & 82.5 & -4.77 & 0.19 \\
\hline 105 & 97.5 & -2.15 & 0.08 \\
\hline 120 & 112.5 & ND & $<0.05$ \\
\hline 480 & NA & ND & $<0.05$ \\
\hline
\end{tabular}




\section{Current and pH}

\begin{tabular}{|c|c|c|}
\hline \multicolumn{3}{|c|}{ PR-1-ox500, 7/11/00 Run } \\
\hline Time (min.) & $\mathbf{I}(\mathbf{m A})$ & PH \\
\hline 0 & NA & 3.50 \\
\hline 15 & 3.05 & 2.54 \\
\hline 30 & 2.05 & 2.60 \\
\hline 45 & 1.85 & 2.71 \\
\hline 60 & 1.80 & 2.76 \\
\hline 75 & 1.80 & 2.80 \\
\hline 90 & 1.75 & 2.83 \\
\hline 105 & 1.75 & 2.85 \\
\hline 135 & 1.70 & 2.89 \\
\hline 195 & 1.60 & 2.87 \\
\hline 300 & 1.55 & 2.87 \\
\hline 480 & 1.50 & 2.87 \\
\hline
\end{tabular}

PR-19-ox400

\begin{tabular}{|r|r|r|r||}
\hline \multicolumn{5}{|c|}{ Initial Run (8/1/00) } \\
\hline $\begin{array}{c}\text { Time } \\
\text { (min.) }\end{array}$ & $\begin{array}{c}\text { Ave. Time } \\
\text { (min.) }\end{array}$ & $\begin{array}{c}\text { Peak Ht. } \\
(: \mathbf{A})\end{array}$ & $\begin{array}{c}\text { Conc. } \\
(\mathbf{p p m})\end{array}$ \\
\hline \hline 0 & 0.0 & $\mathrm{NA}$ & 100.00 \\
\hline 15 & 7.5 & $-1,359.00$ & 53.01 \\
\hline 30 & 22.5 & -92.74 & 3.62 \\
\hline 45 & 37.5 & -24.48 & 0.95 \\
\hline 60 & 52.5 & -16.40 & 0.64 \\
\hline 75 & 67.5 & -19.67 & 0.77 \\
\hline 90 & 82.5 & -4.55 & 0.18 \\
\hline 105 & 97.5 & -1.70 & 0.07 \\
\hline 120 & 112.5 & ND & $<0.05$ \\
\hline 180 & NA & ND & $<0.05$ \\
\hline 240 & NA & -4.08 & 0.16 \\
\hline 480 & NA & -13.76 & 0.54 \\
\hline
\end{tabular}

\begin{tabular}{|r|r|r|r||}
\hline \multicolumn{4}{|c|}{ Subsequent Run (9/11/00) } \\
\hline \hline $\begin{array}{c}\text { Time } \\
\text { (min.) }\end{array}$ & $\begin{array}{c}\text { Ave. Time } \\
\text { (min.) }\end{array}$ & $\begin{array}{c}\text { Peak Ht. } \\
(: \mathbf{)})\end{array}$ & $\begin{array}{c}\text { Conc. } \\
\text { (ppm) }\end{array}$ \\
\hline \hline 0 & 0.0 & NA & 100.00 \\
\hline 15 & 7.5 & -707.80 & 27.61 \\
\hline 30 & 22.5 & -23.35 & 0.91 \\
\hline 45 & 37.5 & ND & $<0.05$ \\
\hline 60 & 52.5 & ND & $<0.05$ \\
\hline 75 & 67.5 & ND & $<0.05$ \\
\hline 90 & 82.5 & -10.38 & 0.40 \\
\hline 105 & 97.5 & ND & $<0.05$ \\
\hline 120 & 112.5 & ND & $<0.05$ \\
\hline 180 & NA & -1.20 & 0.05 \\
\hline 240 & NA & -1.71 & 0.07 \\
\hline 480 & NA & -6.04 & 0.24 \\
\hline
\end{tabular}


PR-1-AG

\begin{tabular}{|r|r|r|r||}
\hline \multicolumn{4}{|c|}{ Initial Run (8/18/00) } \\
\hline \hline $\begin{array}{c}\text { Time } \\
\text { (min.) }\end{array}$ & $\begin{array}{c}\text { Ave. Time } \\
\text { (min.) }\end{array}$ & $\begin{array}{c}\text { Peak Ht. } \\
\text { (:A) }\end{array}$ & $\begin{array}{c}\text { Conc. } \\
\text { (ppm) }\end{array}$ \\
\hline \hline 0 & 0.0 & NA & 100.00 \\
\hline 15 & 7.5 & -933.80 & 36.42 \\
\hline 30 & 22.5 & -52.85 & 2.06 \\
\hline 45 & 37.5 & -13.11 & 0.51 \\
\hline 60 & 52.5 & -7.05 & 0.28 \\
\hline 75 & 67.5 & -7.90 & 0.31 \\
\hline 90 & 82.5 & -3.41 & 0.13 \\
\hline 105 & 97.5 & -18.94 & 0.74 \\
\hline 120 & 112.5 & -2.01 & 0.08 \\
\hline 390 & NA & ND & $<0.05$ \\
\hline 480 & NA & -2.89 & 0.11 \\
\hline
\end{tabular}

\begin{tabular}{|r|r|r|r||}
\hline \multicolumn{5}{|c|}{ Subsequent Run (8/19/00) } \\
\hline \hline $\begin{array}{c}\text { Time } \\
\text { (min.) }\end{array}$ & $\begin{array}{c}\text { Ave. Time } \\
\text { (min.) }\end{array}$ & $\begin{array}{c}\text { Peak Ht. } \\
\text { (:A) }\end{array}$ & $\begin{array}{c}\text { Conc. } \\
\text { (ppm) }\end{array}$ \\
\hline \hline 0 & 0.0 & NA & 100.00 \\
\hline 15 & 7.5 & -924.10 & 36.05 \\
\hline 30 & 22.5 & -26.75 & 1.04 \\
\hline 45 & 37.5 & -11.22 & 0.44 \\
\hline 60 & 52.5 & ND & $<0.05$ \\
\hline 75 & 67.5 & ND & $<0.05$ \\
\hline 90 & 82.5 & -2.03 & 0.08 \\
\hline 105 & 97.5 & -4.57 & 0.18 \\
\hline 120 & 112.5 & -3.14 & 0.12 \\
\hline 420 & NA & -1.21 & 0.05 \\
\hline 480 & NA & -27.44 & 1.07 \\
\hline \hline
\end{tabular}

\section{PR-19-AG}

\begin{tabular}{|r|r|r|r||}
\hline \multicolumn{5}{|c|}{ Initial Run (8/8/00) } \\
\hline \hline $\begin{array}{c}\text { Time } \\
(\text { min.) }\end{array}$ & $\begin{array}{c}\text { Ave. Time } \\
(\mathbf{m i n} .)\end{array}$ & $\begin{array}{c}\text { Peak Ht. } \\
(: \mathbf{)})\end{array}$ & $\begin{array}{c}\text { Conc. } \\
(\mathbf{p p m})\end{array}$ \\
\hline \hline 0 & 0.0 & $\mathrm{NA}$ & 100.00 \\
\hline 15 & 7.5 & -483.10 & 18.84 \\
\hline 30 & 22.5 & -28.27 & 1.10 \\
\hline 45 & 37.5 & -5.97 & 0.23 \\
\hline 60 & 52.5 & -5.32 & 0.21 \\
\hline 75 & 67.5 & ND & $<0.05$ \\
\hline 90 & 82.5 & -3.91 & 0.15 \\
\hline 105 & 97.5 & ND & $<0.05$ \\
\hline 165 & NA & ND & $<0.05$ \\
\hline 300 & NA & -9.04 & 0.35 \\
\hline 435 & NA & -2.73 & 0.11 \\
\hline 480 & NA & ND & $<0.05$ \\
\hline
\end{tabular}

\begin{tabular}{|r|r|r|r||}
\hline \multicolumn{4}{|c|}{ Subsequent Run (8/12/00) } \\
\hline $\begin{array}{c}\text { Time } \\
\text { (min.) }\end{array}$ & $\begin{array}{c}\text { Ave. Time } \\
\text { (min.) }\end{array}$ & $\begin{array}{c}\text { Peak Ht. } \\
\text { (:A) }\end{array}$ & $\begin{array}{c}\text { Conc. } \\
\text { (ppm) }\end{array}$ \\
\hline \hline 0 & 0.0 & NA & 100.00 \\
\hline 15 & 7.5 & -104.50 & 4.08 \\
\hline 30 & 22.5 & -49.98 & 1.95 \\
\hline 45 & 37.5 & -16.35 & 0.64 \\
\hline 60 & 52.5 & -18.05 & 0.70 \\
\hline 75 & 67.5 & -8.35 & 0.33 \\
\hline 90 & 82.5 & -10.27 & 0.40 \\
\hline 105 & 97.5 & -3.43 & 0.13 \\
\hline 120 & 112.5 & -4.27 & 0.17 \\
\hline 135 & NA & -3.90 & 0.15 \\
\hline 480 & NA & ND & $<0.05$ \\
\hline \hline
\end{tabular}




\section{PR-19-HT}

\begin{tabular}{|r|r|r|r||}
\hline \multicolumn{4}{|c|}{ Initial Run (3/21/00) } \\
\hline $\begin{array}{c}\text { Time } \\
\text { (min.) }\end{array}$ & $\begin{array}{c}\text { Ave. Time } \\
\text { (min.) }\end{array}$ & $\begin{array}{c}\text { Peak Ht. } \\
\text { (:A) }\end{array}$ & $\begin{array}{c}\text { Conc. } \\
\text { (ppm) }\end{array}$ \\
\hline \hline 0 & 0.0 & NA & 100.00 \\
\hline 15 & 7.5 & -907.50 & 36.28 \\
\hline 30 & 22.5 & -34.33 & 1.37 \\
\hline 45 & 37.5 & -25.53 & 1.02 \\
\hline 60 & 52.5 & -14.04 & 0.56 \\
\hline 75 & 67.5 & -13.29 & 0.53 \\
\hline 90 & 82.5 & -7.15 & 0.29 \\
\hline 105 & 97.5 & ND & $<0.05$ \\
\hline 120 & 112.5 & -4.17 & 0.17 \\
\hline 150 & NA & ND & $<0.05$ \\
\hline 180 & NA & ND & $<0.05$ \\
\hline 240 & NA & -2.81 & 0.11 \\
\hline 390 & NA & ND & $<0.05$ \\
\hline 480 & NA & -12.32 & 0.49 \\
\hline
\end{tabular}

\begin{tabular}{|r|r|r|r||}
\hline \multicolumn{4}{|c|}{ Subsequent Run (10/12/00) } \\
\hline \hline $\begin{array}{c}\text { Time } \\
\text { (min.) }\end{array}$ & $\begin{array}{c}\text { Ave. Time } \\
\text { (min.) }\end{array}$ & $\begin{array}{c}\text { Peak Ht. } \\
\text { (:A) }\end{array}$ & $\begin{array}{c}\text { Conc. } \\
\text { (ppm) }\end{array}$ \\
\hline \hline 0 & 0.0 & NA & 100.00 \\
\hline 15 & 7.5 & -367.20 & 14.68 \\
\hline 30 & 22.5 & -16.72 & 0.67 \\
\hline 45 & 37.5 & -5.17 & 0.21 \\
\hline 60 & 52.5 & -1.50 & 0.06 \\
\hline 75 & 67.5 & -2.49 & 0.10 \\
\hline 90 & 82.5 & ND & $<0.05$ \\
\hline 105 & 97.5 & -1.47 & 0.06 \\
\hline 120 & 112.5 & ND & $<0.05$ \\
\hline 150 & NA & ND & $<0.05$ \\
\hline 180 & NA & -1.82 & 0.07 \\
\hline 240 & NA & ND & $<0.05$ \\
\hline 390 & NA & ND & $<0.05$ \\
\hline 480 & NA & -4.16 & 0.17 \\
\hline \hline
\end{tabular}

\section{PR-21-PS}

\begin{tabular}{|r|r|r|r||}
\hline \multicolumn{4}{|c|}{ Initial Run (3/20/00) } \\
\hline $\begin{array}{c}\text { Time } \\
\text { (min.) }\end{array}$ & $\begin{array}{c}\text { Ave. Time } \\
\text { (min.) }\end{array}$ & $\begin{array}{c}\text { Peak Ht. } \\
\text { (:A) }\end{array}$ & $\begin{array}{c}\text { Conc. } \\
\text { (ppm) }\end{array}$ \\
\hline \hline 0 & 0.0 & NA & 100.00 \\
\hline 15 & 7.5 & -655.40 & 26.20 \\
\hline 30 & 22.5 & -90.21 & 3.61 \\
\hline 45 & 37.5 & -11.37 & 0.45 \\
\hline 60 & 52.5 & ND & $<0.05$ \\
\hline 75 & 67.5 & -5.87 & 0.23 \\
\hline 90 & 82.5 & ND & $<0.05$ \\
\hline 105 & 97.5 & -3.55 & 0.14 \\
\hline 120 & 112.5 & -8.14 & 0.33 \\
\hline 150 & NA & ND & $<0.05$ \\
\hline 180 & NA & ND & $<0.05$ \\
\hline 240 & NA & -2.27 & 0.09 \\
\hline 385 & NA & ND & $<0.05$ \\
\hline 480 & NA & ND & $<0.05$ \\
\hline \hline
\end{tabular}

\begin{tabular}{|r|r|r|r||}
\hline \multicolumn{4}{|c|}{ Subsequent Run (10/11/00) } \\
\hline \hline $\begin{array}{c}\text { Time } \\
\text { (min.) }\end{array}$ & $\begin{array}{c}\text { Ave. Time } \\
\text { (min.) }\end{array}$ & $\begin{array}{c}\text { Peak Ht. } \\
\text { (:A) }\end{array}$ & $\begin{array}{c}\text { Conc. } \\
\text { (ppm) }\end{array}$ \\
\hline \hline 0 & 0.0 & NA & 100.00 \\
\hline 15 & 7.5 & $-1,215.30$ & 48.58 \\
\hline 30 & 22.5 & -8.47 & 0.34 \\
\hline 45 & 37.5 & -9.76 & 0.39 \\
\hline 60 & 52.5 & -7.82 & 0.31 \\
\hline 75 & 67.5 & -3.51 & 0.14 \\
\hline 90 & 82.5 & -2.72 & 0.11 \\
\hline 105 & 97.5 & ND & $<0.05$ \\
\hline 120 & 112.5 & -5.37 & 0.21 \\
\hline 150 & NA & -5.56 & 0.22 \\
\hline 180 & NA & -1.92 & 0.08 \\
\hline 240 & NA & ND & $<0.05$ \\
\hline 390 & NA & ND & $<0.05$ \\
\hline 480 & NA & -4.18 & 0.17 \\
\hline \hline
\end{tabular}


$\mathrm{CO}_{2}-950$

\begin{tabular}{|r|r|r|r||}
\hline \multicolumn{4}{|c|}{ Initial Run (6/8/00) } \\
\hline \hline $\begin{array}{c}\text { Time } \\
\text { (min.) }\end{array}$ & $\begin{array}{c}\text { Ave. Time } \\
\text { (min.) }\end{array}$ & $\begin{array}{c}\text { Peak Ht. } \\
(: A)\end{array}$ & $\begin{array}{c}\text { Conc. } \\
\text { (ppm) }\end{array}$ \\
\hline \hline 0 & 0.0 & NA & 100.00 \\
\hline 13 & 7.5 & -603.20 & 23.53 \\
\hline 25 & 22.5 & -74.91 & 2.92 \\
\hline 40 & 37.5 & -31.62 & 1.23 \\
\hline 58 & 52.5 & -4.43 & 0.17 \\
\hline 95 & 67.5 & -1.62 & 0.06 \\
\hline 150 & NA & -2.59 & 0.10 \\
\hline 225 & NA & -2.62 & 0.10 \\
\hline 330 & NA & -4.83 & 0.19 \\
\hline 480 & NA & -3.84 & 0.15 \\
\hline
\end{tabular}

\begin{tabular}{|r|r|r|r||}
\hline \multicolumn{4}{|c|}{ Subsequent Run (10/10/00) } \\
\hline \hline $\begin{array}{c}\text { Time } \\
\text { (min.) }\end{array}$ & $\begin{array}{c}\text { Ave. Time } \\
\text { (min.) }\end{array}$ & $\begin{array}{c}\text { Peak Ht. } \\
(: \mathbf{A})\end{array}$ & $\begin{array}{c}\text { Conc. } \\
\text { (ppm) }\end{array}$ \\
\hline \hline 0 & 0.0 & NA & 100.00 \\
\hline 15 & 7.5 & $-1,349.50$ & 52.64 \\
\hline 30 & 22.5 & -44.81 & 1.75 \\
\hline 45 & 37.5 & -8.93 & 0.35 \\
\hline 60 & 52.5 & -3.32 & 0.13 \\
\hline 75 & 67.5 & ND & $<0.05$ \\
\hline 90 & NA & -1.35 & 0.05 \\
\hline 105 & NA & -3.03 & 0.12 \\
\hline 120 & NA & -3.62 & 0.14 \\
\hline 150 & NA & -4.68 & 0.18 \\
\hline 180 & NA & -2.43 & 0.09 \\
\hline 240 & NA & ND & $<0.05$ \\
\hline 360 & NA & ND & $<0.05$ \\
\hline 480 & NA & -7.43 & 0.29 \\
\hline \hline
\end{tabular}

PR-23-HT

\begin{tabular}{|r|r|r|r||}
\hline \multicolumn{5}{|c|}{ Initial Run (7/13/00) } \\
\hline \hline $\begin{array}{c}\text { Time } \\
\text { (min.) }\end{array}$ & $\begin{array}{c}\text { Ave. Time } \\
\text { (min.) }\end{array}$ & $\begin{array}{c}\text { Peak Ht. } \\
\text { (:A) }\end{array}$ & $\begin{array}{c}\text { Conc. } \\
\text { (ppm) }\end{array}$ \\
\hline \hline 0 & 0.0 & NA & 100.00 \\
\hline 15 & 7.5 & $-1,021.60$ & 40.84 \\
\hline 30 & 22.5 & -32.38 & 1.29 \\
\hline 45 & 37.5 & -4.86 & 0.19 \\
\hline 60 & 52.5 & -1.68 & 0.07 \\
\hline 75 & 67.5 & ND & $<0.05$ \\
\hline 90 & 82.5 & ND & $<0.05$ \\
\hline 120 & 105.0 & ND & $<0.05$ \\
\hline 180 & NA & ND & $<0.05$ \\
\hline 480 & NA & -1.32 & 0.05 \\
\hline \hline
\end{tabular}

\begin{tabular}{|r|r|r|r||}
\hline \multicolumn{4}{|c|}{ Subsequent Run (9/20/00) } \\
\hline \hline $\begin{array}{c}\text { Time } \\
\text { (min.) }\end{array}$ & $\begin{array}{c}\text { Ave. Time } \\
\text { (min.) }\end{array}$ & $\begin{array}{c}\text { Peak Ht. } \\
\text { (:A) }\end{array}$ & $\begin{array}{c}\text { Conc. } \\
\text { (ppm) }\end{array}$ \\
\hline \hline 0 & 0.0 & NA & 100.00 \\
\hline 15 & 7.5 & $-1,475.10$ & 57.54 \\
\hline 30 & 22.5 & -24.23 & 0.95 \\
\hline 45 & 37.5 & ND & $<0.05$ \\
\hline 60 & 52.5 & ND & $<0.05$ \\
\hline 75 & 67.5 & ND & $<0.05$ \\
\hline 90 & 82.5 & ND & $<0.05$ \\
\hline 225 & 97.5 & ND & $<0.05$ \\
\hline 330 & 112.5 & ND & $<0.05$ \\
\hline 405 & NA & ND & $<0.05$ \\
\hline 480 & NA & -2.52 & 0.10 \\
\hline \hline
\end{tabular}


PR-24

\begin{tabular}{|r|r|r|r||}
\hline \multicolumn{5}{|c|}{ Initial Run (8/15/00) } \\
\hline \hline $\begin{array}{c}\text { Time } \\
\text { (min.) }\end{array}$ & $\begin{array}{c}\text { Ave. Time } \\
\text { (min.) }\end{array}$ & $\begin{array}{c}\text { Peak Ht. } \\
\text { (:A) }\end{array}$ & $\begin{array}{c}\text { Conc. } \\
\text { (ppm) }\end{array}$ \\
\hline \hline 0 & 0.0 & NA & 100.00 \\
\hline 15 & 7.5 & -860.50 & 33.56 \\
\hline 30 & 22.5 & -42.66 & 1.66 \\
\hline 45 & 37.5 & -14.66 & 0.57 \\
\hline 60 & 52.5 & -4.14 & 0.16 \\
\hline 75 & 67.5 & ND & $<0.05$ \\
\hline 90 & 82.5 & ND & $<0.05$ \\
\hline 105 & 97.5 & ND & $<0.05$ \\
\hline 120 & 112.5 & ND & $<0.05$ \\
\hline 480 & NA & ND & $<0.05$ \\
\hline \hline
\end{tabular}

\begin{tabular}{|r|r|r|r||}
\hline \multicolumn{4}{|c|}{ Subsequent Run (10/13/00) } \\
\hline \hline $\begin{array}{c}\text { Time } \\
(\text { min. })\end{array}$ & $\begin{array}{c}\text { Ave. Time } \\
\text { (min.) }\end{array}$ & $\begin{array}{c}\text { Peak Ht. } \\
(: A)\end{array}$ & $\begin{array}{c}\text { Conc. } \\
\text { (ppm) }\end{array}$ \\
\hline \hline 0 & 0.0 & NA & 100.00 \\
\hline 15 & 7.5 & -869.00 & 33.90 \\
\hline 30 & 22.5 & -27.95 & 1.09 \\
\hline 45 & 37.5 & -7.05 & 0.27 \\
\hline 60 & 52.5 & ND & $<0.05$ \\
\hline 75 & 67.5 & ND & $<0.05$ \\
\hline 90 & 82.5 & ND & $<0.05$ \\
\hline 105 & 97.5 & -5.34 & 0.21 \\
\hline 120 & 112.5 & ND & $<0.05$ \\
\hline 150 & NA & -4.75 & 0.19 \\
\hline 180 & NA & ND & $<0.05$ \\
\hline 240 & NA & -8.94 & 0.35 \\
\hline 360 & NA & ND & $<0.05$ \\
\hline 480 & NA & -2.51 & 0.10 \\
\hline \hline
\end{tabular}

\section{Carbon Black Samples}

\begin{tabular}{||r|r|r|r||}
\hline \multicolumn{4}{|c|}{ PG-195-XB (3/8/00) } \\
\hline \hline $\begin{array}{c}\text { Time } \\
\text { (min.) }\end{array}$ & $\begin{array}{c}\text { Ave. Time } \\
\text { (min.) }\end{array}$ & $\begin{array}{c}\text { Peak Ht. } \\
(: A)\end{array}$ & $\begin{array}{c}\text { Conc. } \\
\text { (ppm) }\end{array}$ \\
\hline \hline 0 & 0.0 & NA & 100.00 \\
\hline 15 & 7.5 & $-2,329.00$ & 93.10 \\
\hline 30 & 22.5 & $-1,959.00$ & 78.31 \\
\hline 45 & 37.5 & $-1,756.00$ & 70.20 \\
\hline 60 & 52.5 & $-2,185.00$ & 87.35 \\
\hline 90 & 82.5 & $-2,424.00$ & 96.90 \\
\hline
\end{tabular}

\begin{tabular}{|r|r|r|r||}
\hline \multicolumn{4}{|c|}{ Superior Graphite,BG-34 (3/15/00) } \\
\hline \hline $\begin{array}{c}\text { Time } \\
\text { (min.) }\end{array}$ & $\begin{array}{c}\text { Ave. Time } \\
\text { (min.) }\end{array}$ & $\begin{array}{c}\text { Peak Ht. } \\
(: A)\end{array}$ & $\begin{array}{c}\text { Conc. } \\
\text { (ppm) }\end{array}$ \\
\hline 0 & 0.0 & NA & 100.00 \\
\hline 15 & 7.5 & -813.20 & 32.51 \\
\hline 30 & 22.5 & -111.80 & 4.47 \\
\hline 45 & 37.5 & $-1,073.00$ & 42.89 \\
\hline 60 & 52.5 & $-1,455.20$ & 58.17 \\
\hline 75 & 67.5 & $-1,552.10$ & 62.05 \\
\hline 90 & 82.5 & $-1,544.20$ & 61.73 \\
\hline 105 & 97.5 & $-1,582.50$ & 63.26 \\
\hline 120 & 112.5 & $-1,666.00$ & 66.60 \\
\hline \hline
\end{tabular}




\section{VARIATION OF EXPERIMENTAL PARAMETERS}

\section{Applied Potential}

\begin{tabular}{|c|c|c|c|c|c|c|c|c|}
\hline \multirow[b]{2}{*}{$\begin{array}{l}\text { Time } \\
\text { (min.) }\end{array}$} & \multicolumn{2}{|c|}{ No Potential } & \multicolumn{2}{|c|}{$-0.1 \mathrm{~V}$} & \multicolumn{2}{|c|}{$-0.2 \mathrm{~V}$} & \multicolumn{2}{|c|}{$-0.3 \mathrm{~V}$} \\
\hline & $\begin{array}{l}\text { Peak Ht } \\
(: A)\end{array}$ & $\begin{array}{l}\text { Conc. } \\
\text { (ppm) }\end{array}$ & $\begin{array}{l}\text { Peak Ht } \\
(: A)\end{array}$ & $\begin{array}{l}\text { Conc. } \\
\text { (ppm) }\end{array}$ & $\begin{array}{l}\text { Peak Ht } \\
(: A)\end{array}$ & $\begin{array}{l}\text { Conc. } \\
\text { (ppm) }\end{array}$ & $\begin{array}{l}\text { Peak Ht } \\
(: A)\end{array}$ & $\begin{array}{l}\text { Conc. } \\
\text { (ppm) }\end{array}$ \\
\hline 0 & NA & 100.00 & NA & 100.00 & NA & 100.00 & NA & 100.00 \\
\hline 15 & $-2,531.00$ & 98.72 & $-2,376.00$ & 92.68 & $-2,126.00$ & 82.93 & $-1,495.00$ & 58.31 \\
\hline 30 & $-2,550.00$ & 99.47 & $-2,555.00$ & 99.66 & $-2,560.00$ & 99.86 & $-2,041.00$ & 79.61 \\
\hline 45 & $-2,560.00$ & 99.86 & $-2,560.00$ & 99.86 & $-2,550.00$ & 99.47 & $-2,419.00$ & 94.36 \\
\hline 60 & $-2,550.00$ & 99.47 & $-2,550.00$ & 99.47 & $-2,531.00$ & 98.72 & $-2,442.00$ & 95.25 \\
\hline 75 & $-2,531.00$ & 98.72 & $-2,560.00$ & 99.86 & $-2,560.00$ & 99.86 & $-2,286.00$ & 89.17 \\
\hline 90 & $-2,550.00$ & 99.47 & $-2,531.00$ & 98.72 & $-2,550.00$ & 99.47 & $-2,211.00$ & 86.24 \\
\hline 105 & $-2,560.00$ & 99.86 & $-2,550.00$ & 99.47 & $-2,531.00$ & 98.72 & $-2,241.00$ & 87.41 \\
\hline 120 & $-2,550.00$ & 99.47 & $-2,560.00$ & 99.86 & $-2,550.00$ & 99.47 & $-2,289.00$ & 89.29 \\
\hline
\end{tabular}

\begin{tabular}{|c|c|c|c|c|c|c|c|c|}
\hline \multirow[b]{2}{*}{$\begin{array}{l}\text { Time } \\
\text { (min.) }\end{array}$} & \multicolumn{2}{|c|}{$-0.4 \mathrm{~V}$} & \multicolumn{2}{|c|}{$-0.5 \mathrm{~V}$} & \multicolumn{2}{|c|}{$-0.7 \mathrm{~V}$} & \multicolumn{2}{|c|}{$-0.9 \mathrm{~V}$} \\
\hline & $\begin{array}{l}\text { Peak Ht } \\
\text { (:A) }\end{array}$ & $\begin{array}{l}\text { Conc. } \\
\text { (ppm) }\end{array}$ & $\begin{array}{l}\text { Peak Ht } \\
(: A)\end{array}$ & $\begin{array}{l}\text { Conc. } \\
\text { (ppm) }\end{array}$ & $\begin{array}{l}\text { Peak Ht } \\
(: A)\end{array}$ & $\begin{array}{l}\text { Conc. } \\
\text { (ppm) }\end{array}$ & $\begin{array}{l}\text { Peak Ht } \\
(: A)\end{array}$ & $\begin{array}{l}\text { Conc. } \\
\text { (ppm) }\end{array}$ \\
\hline "0 & NA & 100.00 & 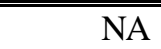 & 100.00 & NA & 100.00 & NA & 100.00 \\
\hline 15 & $-1,255.00$ & 48.95 & -870.50 & 33.95 & -629.70 & 24.56 & -423.17 & 16.51 \\
\hline 30 & -249.70 & 9.74 & -174.00 & 6.79 & -75.12 & 2.93 & -7.37 & 0.29 \\
\hline 45 & -348.40 & 13.59 & -69.90 & 2.73 & -20.65 & 0.81 & -1.51 & 0.06 \\
\hline 60 & -383.40 & 14.95 & ND & $<0.05$ & -4.61 & 0.18 & ND & $<0.05$ \\
\hline 75 & -319.60 & 12.47 & -6.76 & 0.26 & ND & $<0.05$ & -8.12 & 0.32 \\
\hline 90 & -326.00 & 12.72 & ND & $<0.05$ & -1.33 & 0.05 & -4.45 & 0.17 \\
\hline 105 & -334.10 & 13.03 & -5.61 & 0.22 & ND & $<0.05$ & -2.65 & 0.10 \\
\hline 120 & -344.00 & 13.42 & ND & $<0.05$ & -6.16 & 0.24 & ND & $<0.05$ \\
\hline
\end{tabular}




\section{Flow Rate}

\begin{tabular}{|c|c|c|c|c|c|c|c|c|}
\hline \multirow[b]{2}{*}{$\begin{array}{l}\text { Time } \\
\text { (min.) }\end{array}$} & \multicolumn{2}{|c|}{$0.7 \mathrm{~mL} / \mathrm{min}$} & \multicolumn{2}{|c|}{$1.4 \mathrm{~mL} / \mathrm{min}$} & \multicolumn{2}{|c|}{$1.8 \mathrm{~mL} / \mathrm{min}$} & \multicolumn{2}{|c|}{$2.1 \mathrm{~mL} / \mathrm{min}$} \\
\hline & $\begin{array}{l}\text { Peak Ht } \\
\text { (:A) }\end{array}$ & $\begin{array}{l}\text { Conc. } \\
\text { (ppm) }\end{array}$ & $\begin{array}{l}\text { Peak Ht } \\
(: A)\end{array}$ & $\begin{array}{l}\text { Conc. } \\
\text { (ppm) }\end{array}$ & $\begin{array}{c}\text { Peak Ht } \\
(: A)\end{array}$ & $\begin{array}{l}\text { Conc. } \\
\text { (ppm) }\end{array}$ & $\begin{array}{l}\text { Peak Ht } \\
(: A)\end{array}$ & $\begin{array}{l}\text { Conc. } \\
\text { (ppm) }\end{array}$ \\
\hline 0 & NA & 100.00 & NA & 100.00 & NA & 100.00 & NA & 100.00 \\
\hline 15 & -974.10 & 38.00 & $-1,007.40$ & 39.29 & $-1,117.30$ & 43.58 & $-1,308.50$ & 51.04 \\
\hline 30 & -16.24 & 0.63 & -22.75 & 0.89 & -333.00 & 12.99 & -757.80 & 29.56 \\
\hline 45 & -1.51 & 0.06 & -16.26 & 0.63 & -147.30 & 5.75 & -541.30 & 21.11 \\
\hline 60 & $\mathrm{ND}$ & $<0.05$ & ND & $<0.05$ & -127.40 & 4.97 & -482.60 & 18.82 \\
\hline 75 & -8.12 & 0.32 & -8.64 & 0.34 & -133.70 & 5.22 & -448.90 & 17.51 \\
\hline 90 & -4.45 & 0.17 & ND & $<0.05$ & -124.50 & 4.86 & -426.80 & 16.65 \\
\hline 105 & $\mathrm{ND}$ & $<0.05$ & -4.73 & 0.18 & -125.60 & 4.90 & -433.80 & 16.92 \\
\hline 120 & -6.17 & 0.24 & -5.86 & 0.23 & -119.70 & 4.67 & -425.40 & 16.59 \\
\hline
\end{tabular}

\section{pH}

\begin{tabular}{|c|c|c|c|c|c|c|}
\hline & \multicolumn{2}{|c|}{2.0} & \multicolumn{2}{|c|}{3.5} & \multicolumn{2}{|c|}{5.0} \\
\hline $\begin{array}{l}\text { Time } \\
\text { (min.) }\end{array}$ & $\begin{array}{l}\text { Peak Ht } \\
(: A)\end{array}$ & $\begin{array}{l}\text { Conc. } \\
\text { (ppm) }\end{array}$ & $\begin{array}{l}\text { Peak Ht } \\
(: A)\end{array}$ & $\begin{array}{l}\text { Conc. } \\
\text { (ppm) }\end{array}$ & $\begin{array}{l}\text { Peak Ht } \\
\text { (:A) }\end{array}$ & $\begin{array}{l}\text { Conc. } \\
\text { (ppm) }\end{array}$ \\
\hline "0 & NA & 100.00 & NA & 100.00 & NA & "100.00 \\
\hline 15 & $-2,184.00$ & 85.19 & $-1,007.40$ & 39.29 & -576.30 & 22.48 \\
\hline 30 & $-2,037.00$ & 79.46 & -26.24 & 1.02 & -22.15 & 0.86 \\
\hline 45 & $-1,741.00$ & 67.91 & -1.51 & 0.06 & -9.78 & 0.38 \\
\hline 60 & $-1,523.70$ & 59.43 & -1.48 & 0.06 & $\mathrm{ND}$ & $<0.05$ \\
\hline 75 & $-1,123.70$ & 43.83 & -8.12 & 0.32 & ND & $<0.05$ \\
\hline 90 & -953.60 & 37.20 & -4.45 & 0.17 & $\mathrm{ND}$ & $<0.05$ \\
\hline 105 & $-1,573.70$ & 61.38 & -265 & 0.10 & $\mathrm{ND}$ & $<0.05$ \\
\hline 120 & $-1,710.00$ & 66.70 & -2.19 & 0.09 & $\mathrm{ND}$ & $<0.05$ \\
\hline
\end{tabular}




\section{CYCLIC LOADING/UNLOADING}

\begin{tabular}{|r|r|r||}
\hline \multicolumn{3}{|c|}{ Initial Pass } \\
\hline \hline $\begin{array}{c}\text { Time } \\
\text { (min.) }\end{array}$ & $\begin{array}{c}\text { Peak Ht. } \\
\text { (:A) }\end{array}$ & $\begin{array}{c}\text { Conc. } \\
\text { (ppm) }\end{array}$ \\
\hline \hline 0 & NA & 100.00 \\
\hline 15 & $-1,007.40$ & 39.29 \\
\hline 30 & -26.24 & 1.02 \\
\hline 45 & ND & $<0.05$ \\
\hline 60 & ND & $<0.05$ \\
\hline 75 & -7.65 & 0.30 \\
\hline 90 & -4.45 & 0.17 \\
\hline 105 & ND & $<0.05$ \\
\hline 120 & -2.19 & 0.09 \\
\hline
\end{tabular}

\begin{tabular}{|r|r|r||}
\hline \multicolumn{3}{|c|}{ Subsequent Pass (1) } \\
\hline \hline $\begin{array}{c}\text { Time } \\
\text { (min.) }\end{array}$ & $\begin{array}{c}\text { Peak Ht. } \\
\text { (:A) }\end{array}$ & $\begin{array}{c}\text { Conc. } \\
\text { (ppm) }\end{array}$ \\
\hline \hline 0 & NA & 100.00 \\
\hline 15 & -873.95 & 34.09 \\
\hline 30 & -15.13 & 0.59 \\
\hline 45 & ND & $<0.05$ \\
\hline 60 & -1.29 & 0.05 \\
\hline 75 & ND & $<0.05$ \\
\hline 90 & ND & $<0.05$ \\
\hline 105 & -3.67 & \\
\hline 120 & ND & $<0.05$ \\
\hline
\end{tabular}

\begin{tabular}{|r|r|r||}
\hline \multicolumn{3}{|c|}{ Subsequent Pass (2) } \\
\hline \hline $\begin{array}{c}\text { Time } \\
\text { (min.) }\end{array}$ & $\begin{array}{c}\text { Peak Ht. } \\
\text { (:A) }\end{array}$ & $\begin{array}{c}\text { Conc. } \\
\text { (ppm) }\end{array}$ \\
\hline \hline 0 & NA & 100.00 \\
\hline 15 & -745.63 & 29.08 \\
\hline 30 & -7.32 & 0.29 \\
\hline 45 & ND & $<0.05$ \\
\hline 60 & ND & $<0.05$ \\
\hline 75 & -1.27 & 0.05 \\
\hline 90 & ND & $<0.05$ \\
\hline 105 & -3.33 & 0.13 \\
\hline 120 & ND & $<0.05$ \\
\hline
\end{tabular}

\begin{tabular}{|r|r|r||}
\hline \multicolumn{3}{|c|}{ Subsequent Pass (3) } \\
\hline \hline $\begin{array}{c}\text { Time } \\
\text { (min.) }\end{array}$ & $\begin{array}{c}\text { Peak Ht. } \\
\text { (:A) }\end{array}$ & $\begin{array}{c}\text { Conc. } \\
\text { (ppm) }\end{array}$ \\
\hline \hline 0 & NA & 100.00 \\
\hline 15 & -799.23 & 31.17 \\
\hline 30 & -9.56 & 0.37 \\
\hline 45 & -5.46 & 0.21 \\
\hline 60 & ND & $<0.05$ \\
\hline 75 & ND & $<0.05$ \\
\hline 90 & -3.21 & 0.13 \\
\hline 105 & ND & $<0.05$ \\
\hline 120 & -1.89 & 0.07 \\
\hline
\end{tabular}

\begin{tabular}{|r|r|r||}
\hline \multicolumn{3}{|c|}{ Subsequent Pass (4) } \\
\hline \hline $\begin{array}{c}\text { Time } \\
\text { (min.) }\end{array}$ & $\begin{array}{c}\text { Peak Ht. } \\
\text { (:A) }\end{array}$ & $\begin{array}{c}\text { Conc. } \\
\text { (ppm) }\end{array}$ \\
\hline \hline 0 & NA & 100.00 \\
\hline 15 & -676.33 & 26.38 \\
\hline 30 & -8.73 & 0.34 \\
\hline 45 & -4.87 & 0.19 \\
\hline 60 & ND & $<0.05$ \\
\hline 75 & -3.25 & 0.13 \\
\hline 90 & ND & $<0.05$ \\
\hline 105 & -5.61 & 0.22 \\
\hline 120 & ND & $<0.05$ \\
\hline
\end{tabular}

\begin{tabular}{|r|r|r||}
\hline \multicolumn{3}{|c|}{ Subsequent Pass (5) } \\
\hline \hline $\begin{array}{c}\text { Time } \\
\text { (min.) }\end{array}$ & $\begin{array}{c}\text { Peak Ht. } \\
\text { (:A) }\end{array}$ & $\begin{array}{c}\text { Conc. } \\
\text { (ppm) }\end{array}$ \\
\hline \hline 0 & NA & 100.00 \\
\hline 15 & -714.56 & 27.87 \\
\hline 30 & -12.34 & 0.48 \\
\hline 45 & -6.74 & 0.26 \\
\hline 60 & ND & $<0.05$ \\
\hline 75 & ND & $<0.05$ \\
\hline 90 & -2.67 & 0.10 \\
\hline 105 & ND & $<0.05$ \\
\hline 120 & ND & $<0.05$ \\
\hline
\end{tabular}


CAPACITY

\begin{tabular}{|r|r|r|r||}
\hline \multicolumn{5}{|c|}{ Capacity $\mathbf{5 . 4 5} \mathbf{g}_{\text {uranium }} / \mathbf{g}_{\text {carbon }}$} \\
\hline \hline \multirow{2}{*}{ Time (min.) } & Ave. Time (min) & Peak Ht. (:A) & Conc. (ppm) \\
\hline \hline 0 & 0.0 & NA & 100.00 \\
\hline 15 & 7.5 & $-16,680.00$ & 650.62 \\
\hline 30 & 22.5 & $-9,827.00$ & 383.31 \\
\hline 45 & 37.5 & $-8,541.00$ & 333.15 \\
\hline 60 & 52.5 & $-7,811.00$ & 304.68 \\
\hline 90 & 75.0 & $-7,246.00$ & 282.64 \\
\hline 120 & 105.0 & $-6,985.00$ & 272.46 \\
\hline 240 & NA & $-5,693.00$ & 222.06 \\
\hline 405 & NA & $-5,455.00$ & 212.78 \\
\hline 585 & NA & $-5,720.00$ & 223.12 \\
\hline 780 & NA & $-5,749.00$ & 224.25 \\
\hline 1,560 & NA & $-8,259.00$ & 322.15 \\
\hline 2,115 & NA & $-18,770.00$ & 732.14 \\
\hline 2,370 & NA & $-21,316.00$ & 831.45 \\
\hline
\end{tabular}

RESIDUAL ASH

\begin{tabular}{|c|c|c|c|c|}
\hline Initial Test & 苍苛 & 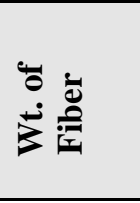 & 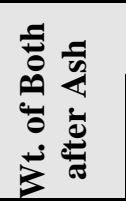 & 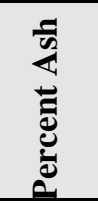 \\
\hline PR-1-ox400 & 8.45 & 0.63 & 8.46 & $1.73 \%$ \\
\hline PR-1-ox500 & 9.44 & 0.52 & 9.45 & $2.67 \%$ \\
\hline PR-19-ox400 & 8.52 & 0.61 & 8.53 & $2.38 \%$ \\
\hline PR-1-AG & 9.28 & 0.72 & 9.29 & $1.36 \%$ \\
\hline PR-19-AG & 8.76 & 0.64 & 8.78 & $3.70 \%$ \\
\hline PR-19-HT & 9.45 & 0.71 & 9.45 & $0.00 \%$ \\
\hline PR-21-PS & 8.76 & 0.58 & 8.78 & $3.85 \%$ \\
\hline $\mathrm{CO}_{2}-950$ & 18.74 & 0.52 & 18.75 & $2.28 \%$ \\
\hline PR-23-HT & 9.43 & 0.63 & 9.43 & $0.00 \%$ \\
\hline PR-24 & 8.72 & 0.54 & 8.73 & $1.81 \%$ \\
\hline
\end{tabular}

\begin{tabular}{|c|c|c|c|c|}
\hline $\begin{array}{c}\text { Duplicate } \\
\text { Test }\end{array}$ & ن & 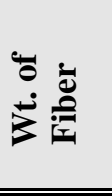 & 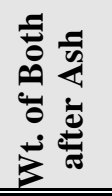 & 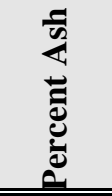 \\
\hline PR-1-ox400 & 9.28 & 0.54 & 9.28 & $1.79 \%$ \\
\hline PR-1-ox500 & 9.38 & 0.59 & 9.39 & $2.95 \%$ \\
\hline PR-19-ox400 & 9.71 & 0.68 & 9.72 & $2.75 \%$ \\
\hline PR-1-AG & 8.99 & 0.63 & 9.00 & $1.37 \%$ \\
\hline PR-19-AG & 8.60 & 0.61 & 8.63 & $3.67 \%$ \\
\hline PR-19-HT & 8.94 & 0.73 & 8.94 & $0.00 \%$ \\
\hline PR-21-PS & 9.36 & 0.54 & 9.37 & $2.57 \%$ \\
\hline $\mathrm{CO}_{2}-950$ & 20.56 & 0.58 & 20.57 & $2.43 \%$ \\
\hline PR-23-HT & 9.21 & 0.69 & 9.21 & $0.00 \%$ \\
\hline PR-24 & 9.09 & 0.52 & 9.10 & $1.87 \%$ \\
\hline
\end{tabular}

